Bulgaria: 2011 Article IV Consultation - Staff Report; Public Information Notice on the Executive Board Discussion; and Statement by the Executive Director for Bulgaria 


\title{
Bulgaria: 2011 Article IV Consultation-Staff Report; Public Information Notice on the Executive Board Discussion; and Statement by the Executive Director for Bulgaria
}

Under Article IV of the IMF's Articles of Agreement, the IMF holds bilateral discussions with members, usually every year. In the context of the 2011 Article IV consultation with Bulgaria, the following documents have been released and are included in this package:

- The staff report for the 2011 Article IV consultation, prepared by a staff team of the IMF, following discussions that ended on May 20, 2011, with the officials of Bulgaria on economic developments and policies. Based on information available at the time of these discussions, the staff report was completed on June 15, 2011. The views expressed in the staff report are those of the staff team and do not necessarily reflect the views of the Executive Board of the IMF.

- $\quad$ A Public Information Notice (PIN) summarizing the views of the Executive Board as expressed during its June 29, 2001 discussion of the staff report that concluded the Article IV consultation.

- $\quad$ A statement by the Executive Director for Bulgaria.

The policy of publication of staff reports and other documents allows for the deletion of market-sensitive information.

\author{
Copies of this report are available to the public from \\ International Monetary Fund • Publication Services \\ $70019^{\text {th }}$ Street, N.W. • Washington, D.C. 20431 \\ Telephone: (202) 623-7430 • Telefax: (202) 623-7201 \\ E-mail: publications@imf.org Internet: http://www.imf.org
}

\section{International Monetary Fund Washington, D.C.}




\title{
INTERNATIONAL MONETARY FUND
}

\author{
BULGARIA
}

\section{Staff Report for the 2011 Article IV Consultation}

Prepared by Staff Representatives for the 2011 Consultation with Bulgaria

Approved by Anne-Marie Gulde-Wolf and Aasim Husain

June 15, 2011

\begin{abstract}
Key Issues
Context: The economy has adjusted rapidly following the 2008-10 crisis with an exportled recovery. Fiscal consolidation is being front-loaded, and the banking system remains well capitalized and stable. Still domestic demand remains weak amid high unemployment and rising food and fuel prices, and the economy is vulnerable to risks from turbulence in the euro area periphery. Presidential and municipal elections are scheduled for October 2011.
\end{abstract}

Challenges: The challenge going forward will be to address potential risks from an uncertain external environment while also accelerating on-going reforms to regain growth potential, create jobs, and address aging-related pressures. This would enhance economic resilience and reinforce the currency board arrangement as the bridge to eventual euro adoption.

Authorities' response: The authorities agreed with the need to reignite structural reform, seeing the National Reform Program (NRP) as meeting that need and point to the substantial progress in utilizing EU funds to finance reform priorities. They underscored their commitment to fiscal discipline evidenced by the ambitious adjustment underway to permit a quick exit from the excessive deficit procedure and new Financial Stability Pact that imposes constitutional limits on the deficit and spending. While acknowledging remaining vulnerabilities and risks, they believe Bulgaria's fiscal and financial buffers, and its strong contingency planning framework, leave it well placed to counter them.

Previous IMF advice: Bulgaria and the IMF maintain excellent relations and policy implementation has been consistent with Executive Board recommendations. During the crisis, the authorities drew on previously built buffers, a position supported by IMF advice. A major pension reform was approved in 2010 to tackle financial pressures in the pension system, a key concern of recent consultations. The 2008 FSAP Update recommendations on purchase and assumption frameworks are awaiting greater clarity about the new EU bank resolution framework.

Mission team: Ms. Purfield (Head), Ms. Mitra, Messrs. Lybek and Pouvelle, (all EUR), Andritzky (FAD), Grigorian and Hesse, (both MCM), and Vesperoni (SPR). Staff met with Finance Minister Djankov, Central Bank Governor Iskrov, EU Funds Minister Donchev, Labor Minister Mladenov, other senior officials, and representatives of the private sector. It also met with labor unions and employers' associations to prepare for the Fall IMFITUC-ILO Job Creation Forum. Mr. Manchev (OED) also participated. 
I. Macroeconomic Setting: Sizeable and Rapid Adjustment .......................................... 4

II. Outlook: Recovery Faces Headwinds and Risks Remain Elevated ............................... $\underline{8}$

III. Policy Challenges: Managing Risks While Reinvigorating Growth .............................. 9

A. Structural Reforms: Reigniting the Reform Momentum .......................................... $\underline{9}$

B. Fiscal Policy: Growth-Enhancing Adjustment ...............................................

C. Financial Sector: Maintaining Resilience.......................................................... 18

D. Rebuilding Reserves and Fiscal Financing ..................................................... $\underline{20}$

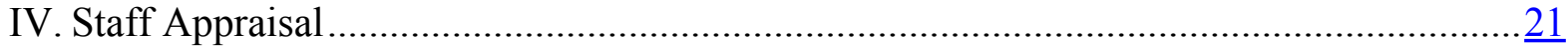

Boxes

1. Exports: Developments and Prospects .................................................................................. 7

2. The Real Effective Exchange Rate (REER) ...................................................... 12

3. EU Funds Absorption: Maximizing the Potential .................................................. 13

4. Public Pension Reform ........................................................................................... $\frac{16}{17}$

5. Options for a Fiscal Rule to Complement the Financial Stability Pact...........................17

Figures

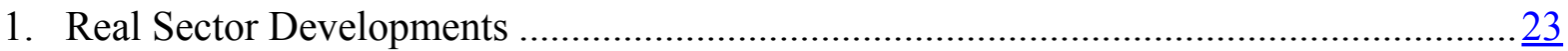

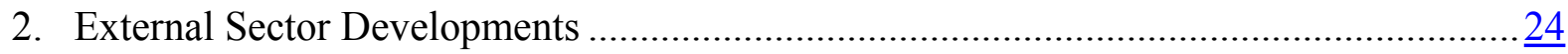

3. Inflation and Monetary Developments ........................................................... 25

4. Labor Market Developments ............................................................................. $\frac{26}{27}$

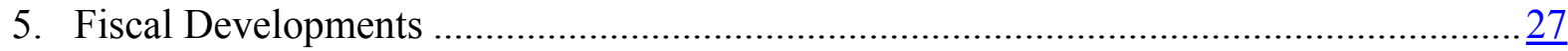

6. Overview of Financial Stability Indicators in Emerging Europe, 2008-10 .................. 28

Tables

1. Selected Economic and Social Indicators, 2008-12 ...............................................29

2. Macroeconomic Framework, 2008-16 …............................................................... $\frac{30}{31}$

3. Real GDP Components, 2008-16......................................................................... $\underline{31}$

4. Balance of Payments, 2008-16 ............................................................................. $\frac{32}{33}$

5a. General Government Operations, 2008-16 (In millions of leva) .................................. $\underline{33}$

5b. General Government Operations, 2008-16 (In percent of GDP) ................................... $\underline{34}$

6. Monetary Accounts, 2008-12 ............................................................................. $\frac{35}{36}$

7. Financial Soundness Indicators, 2008-11 …................................................... $\frac{36}{37}$

8. External Financial Assets and Liabilities, 2008-16 ................................................. 37

Appendices

I. External Debt Sustainability Analysis ................................................................ $\frac{38}{43}$

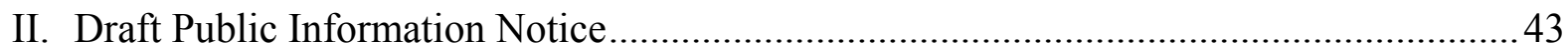


Figures

I.1. External Debt Sustainability: Bound Tests $\underline{39}$

I.2 Public Debt Sustainability: Bound Tests.

Tables

I.1. External Debit Sustainability Framework, 2006-16 $\underline{41}$

I.2 Public Sector Debt Sustainability Framework, 2006-16 ......................................... 42 


\section{Macroeconomic Setting: SizeAble ANd RAPID AdJUSTMENT}

\section{The economy is gradually recovering on the back of strong export growth}

(Figure 1). After contracting 5.5 percent in 2009, economic growth stabilized in 2010 with 0.2 percent real GDP growth. Amid revived global demand, high international commodities prices, and gains in market share, exports have rebounded above their pre-crisis peaks (Box 1). The recovery proceeded in Q1 2011, with real GDP growth expanding by 11/2 percent. Exports remained the sole driver of growth. Consumption and investment continued to contract reflecting weak investor and consumer confidence in the wake of high unemployment, rising inflation and precautionary savings amid heightened regional uncertainty.

2. The current account has adjusted fully unwinding past imbalances (Figure 2). High export growth coupled with depressed imports resulted in the current account deficit retreating from 23 to 1 percent of GDP between 2008 and 2010. On a 12-month rolling basis, it registered a surplus of 1.6 percent of GDP by Q1 2011. Since end-2008, Bulgaria has experienced large capital outflows as banks and the private sector deleveraged reducing total external indebtedness to $931 \frac{1}{2}$ percent of GDP by end-March. These outflows were more than offset by FDI inflows, which despite the decline of non-tradable related flows, remained positive throughout the downturn and supported export performance.
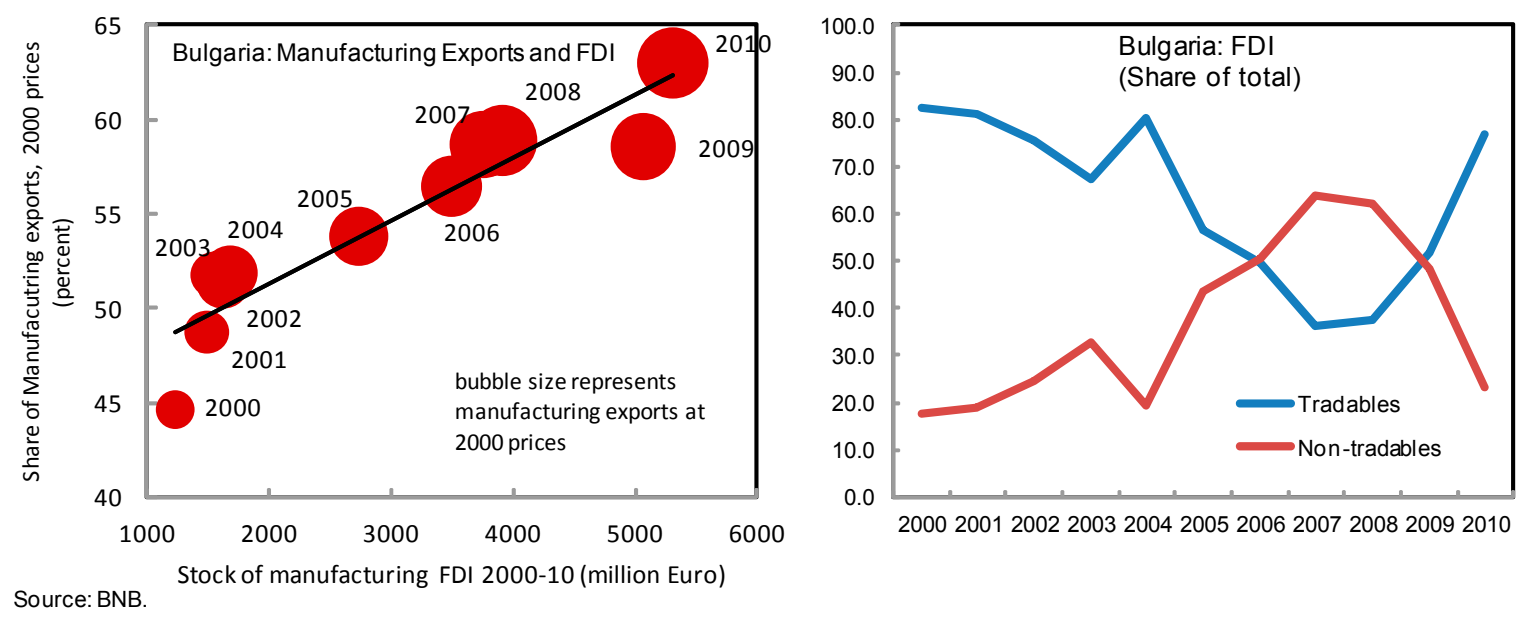

3. Bulgarian financial and asset markets have remained stable. While the recovery in stock market capitalization has lagged that of other emerging European markets, CDS spreads have halved relative to mid-2010 despite the tensions in euro area financial markets. Bulgaria has also benefited from upgrades to its sovereign rating outlook. Increasing deposits and a shrinking Leva-euro interest rate differential point to continued strong confidence in the currency board arrangement (CBA). Residential real estate prices, are 35 percent below their Q3 2008 peak, but are now showing signs of stabilization in larger urban areas. 

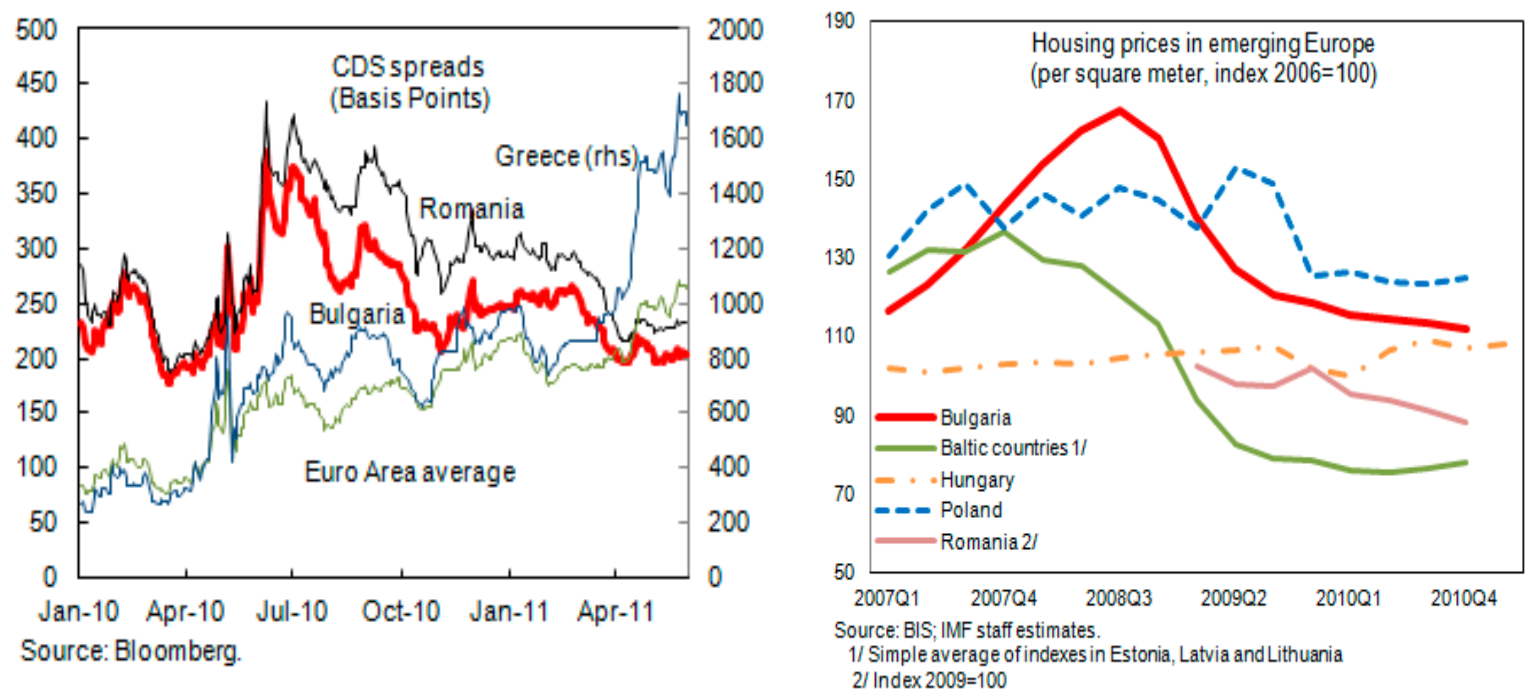

\section{Inflation has risen with food and energy prices, but core inflation remains}

subdued. In contrast to some Eastern

European countries, Bulgaria did not

experience core deflation during the crisis.

More recently, HICP inflation accelerated

in the latter part of 2010 reflecting increases

in global commodity prices (Figure 3 ). Core

inflation, also begun to pick-up from low

levels. However, pressures are easing.

Headline HICP inflation eased to

3.3 percent $y / y$ in April 2011, as the effect of last year's excise increase unwound.

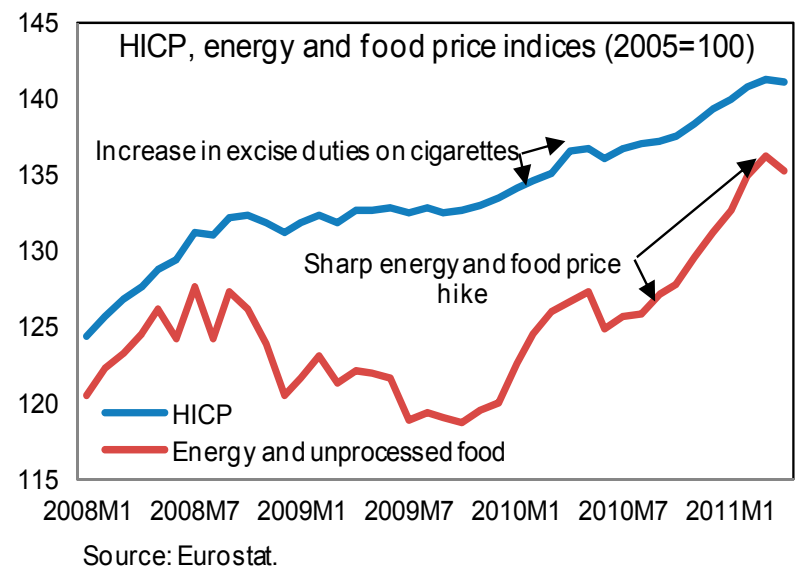

\section{Unemployment doubled over the course of the downturn and remains high}

(Figure 4). Registered unemployment peaked at 10.3 percent in 2010, although labor force data suggest it continued to rise to about 12 percent in Q1 2011. The increase was sharpest amongst the young, where Bulgaria experienced one of the largest increases outside the Baltics. Job destruction was most severe in manufacturing, services and construction. Sharp employment reduction contributed to a 6.4 percent increase in output per worker in 2010 .

\section{Prompt and sizeable fiscal adjustment helped contain the budgetary impact of the}

downturn. The crisis triggered a sharp decline in government revenues (Figure 5). While Bulgaria was able draw on its fiscal buffer (accumulated from past fiscal surpluses) to cushion the shock, after years of rapid growth, expenditures needed to adjust to lower revenue levels. In 2010, expenditure-led adjustment_-including substantial reductions in public sector employment and capital outlays, and a wage and pension bill freeze-contained the 2010 deficit (ESA95 basis) to 3.2 percent of GDP (target of 3.8 percent of GDP). Arrears 
accumulated by end-2009 (1 percent of GDP) were almost halved. A pension reform that raised the contribution rate, increased service period and the retirement age was also passed with the social partners' support. The deficit was largely financed by drawdown of the fiscal reserve, which by end-2010 was almost half its pre-crisis level, and public debt remained low at 16.2 percent of GDP.

\section{Prudent regulatory policies allowed the banking system to weather the crisis well}

(Figure 6). On average profits remain positive and all banks have a capital adequacy ratio (CAR) of over 12 percent (system average 17.7 percent at end-March). As in other countries, nonperforming loans (NPLs) have risen, reaching 12.9 percent by end-March 2011. Having entered the crisis with conservative regulatory standards and high capital levels, the BNB reduced risk weights on bank capital for retail exposures and mortgages to the EU minimum which helped boost the CAR in 2010. It also relaxed its loan classification and provisioning requirement rules to reduce pressure on banks and encouraged banks to retain profits. Nevertheless, the ratio of provisions to loans of about 70 percent remains high by regional standards. With credit demand subdued — credit grew by a modest 1.3 percent in 2010 - and retail deposits growing robustly (Figure 3), foreign-owned banks have reduced their reliance on parent funding. The system-wide loan-to-deposit ratio has fallen to 113 percent and the ratio of liquid assets to short-term liabilities stands at 30.6 percent.
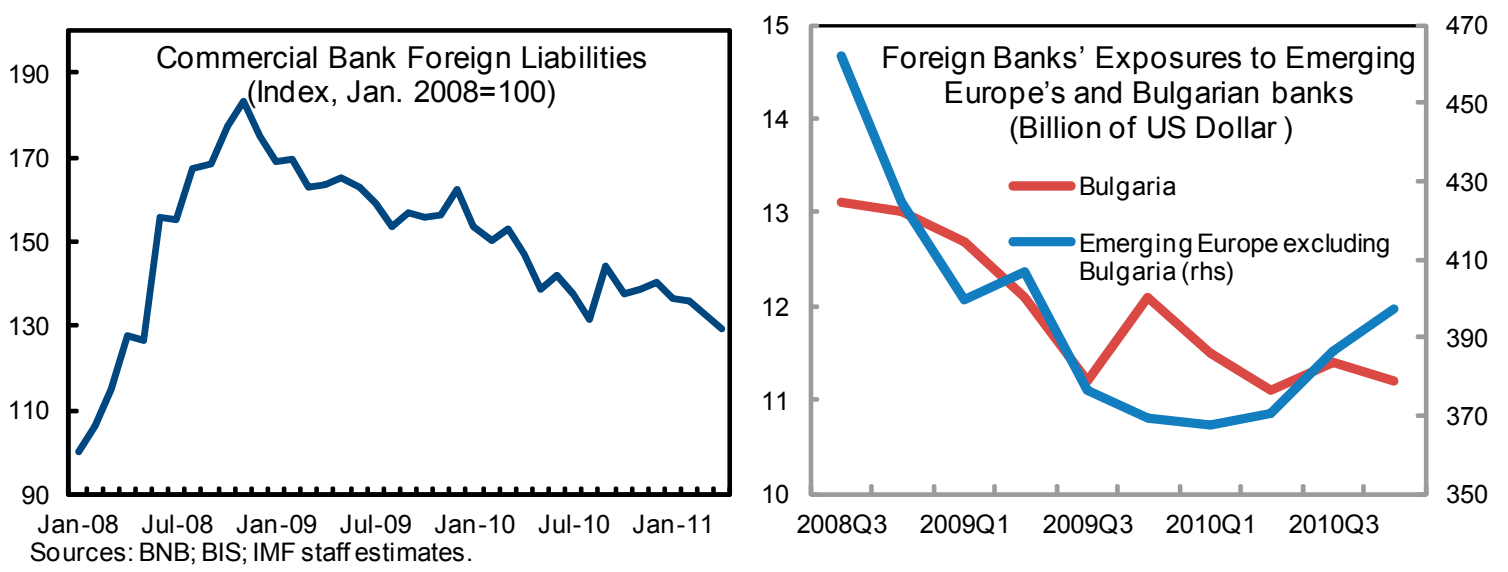

8. The non-bank financial sector-comprising insurance companies, pension funds, collective investment schemes, and leasing companies - continues to develop. Insurance companies and pension funds' assets rose in 2010, but at 9.7 percent of GDP, they are one-tenth of banking sector assets. Even though the non-life insurance sector was severely hit by the financial crisis and registered losses in 2010, its solvency ratio remains high (187 percent at end-2010). 


\section{Box 1. Exports: Developments and Prospects}

Exports buoyancy during the last decade suggests that tradables can contribute significantly to economic growth in coming years.

Export growth has been high during the last decade, and manufacturing exports the most dynamic. Exports volumes increased by 12 percent on average in 2000-08, and by 9 percent last year. While commodity exports were in part boosted by high prices, the increase in manufacturing exports was associated with volumes, which increased by more than 15 percent during 2000-08. The recent recovery was also led by manufacturing.

\section{Within manufacturing exports,} investment goods were the most buoyant. Second to exports of clothing and footwear in the early $2000 \mathrm{~s}$, investment goods (such as machinery and equipment) took the lead in manufacturing by the mid-2000s. The strong recovery of these exports

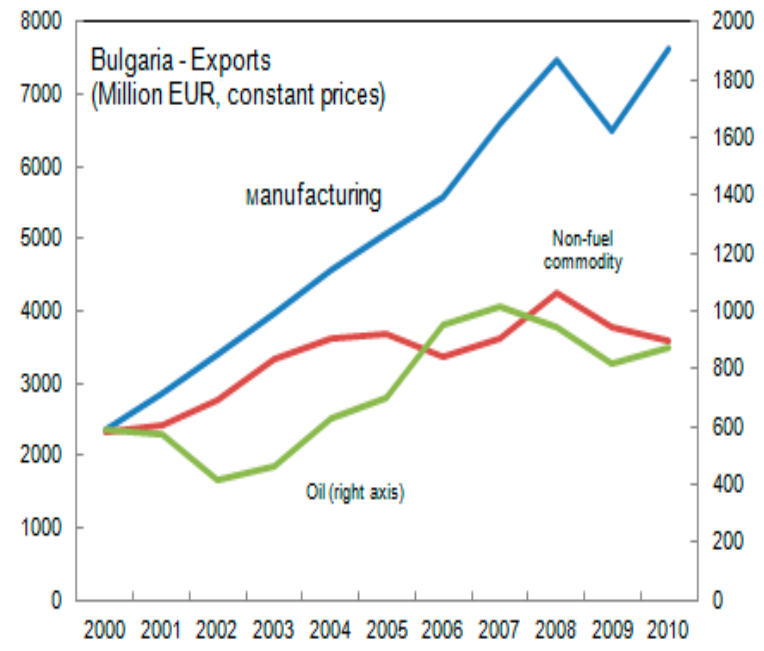

Source: BNB; WEO. since 2009 suggests that the sector has built the capacity to continue its expansion in coming years.

Bulgaria's main market is the European Union (EU). It demands more than 60 percent of exports (about 65 percent of investment goods, 75 percent of consumption goods, and 60 percent of commodities). Other European countries hold a 25 percent share in exports, mainly in commodities and energy. Exports to Asia-although low at 9 percent of the total-are increasing, especially investment goods. At the country level, Germany holds the highest share (11 percent of exports), followed by Italy (10 percent), and Romania and Turkey (9 percent each).

\section{Bulgaria experienced a large increase in} market share during the last 10 years. Its share in world imports almost doubled, in line with the highest performers within

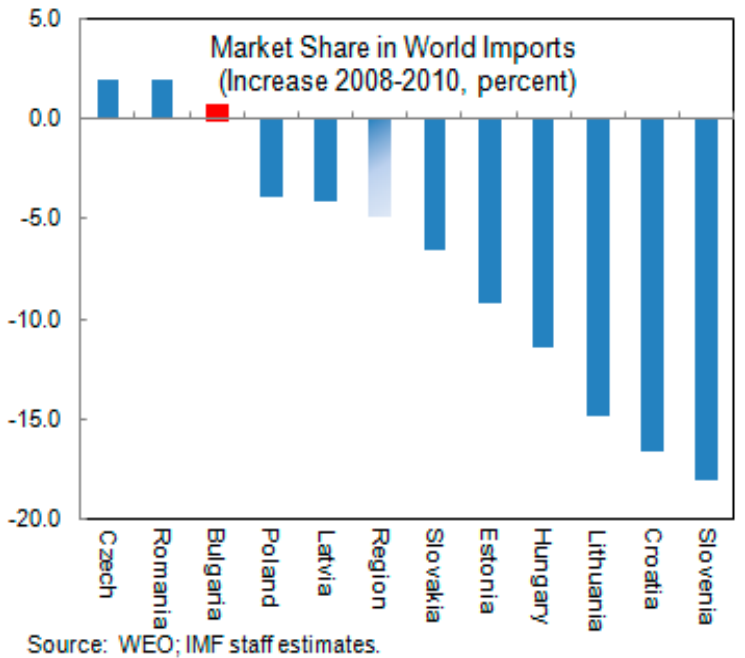
Central and Eastern Europe. Moreover, due to exports' strong recovery in 2010, Bulgaria's recent increase in market share was among the highest in the region.

FDI will be important for continued exports buoyancy. The experience during the last 10 years suggests that the gradual increase in manufacturing FDI stock have been instrumental in boosting export volumes. Hence, sustained strong FDI to manufacturing will be key to fostering exports and higher economic growth. 


\section{OUTLOOK: RECOVERY FACES HEADWINDS AND RISKS REMAIN ELEVATED}

\section{The near-term outlook is for modest growth as headwinds from high} unemployment and uncertainty weigh on domestic demand (Table 1). Export growth is expected to remain strong and allow real GDP to grow by 3 percent in 2011. Reflecting spillovers to domestic demand from exports and increased EU funds absorption, investment, and then consumption, is expected to strengthen later this year and next helping raise GDP growth to $3 \frac{1}{2}$ percent in 2012 . Import demand would remain subdued and the current account deficit is expected to move closer to balance. With FDI inflows gradually increasing and the non-bank private

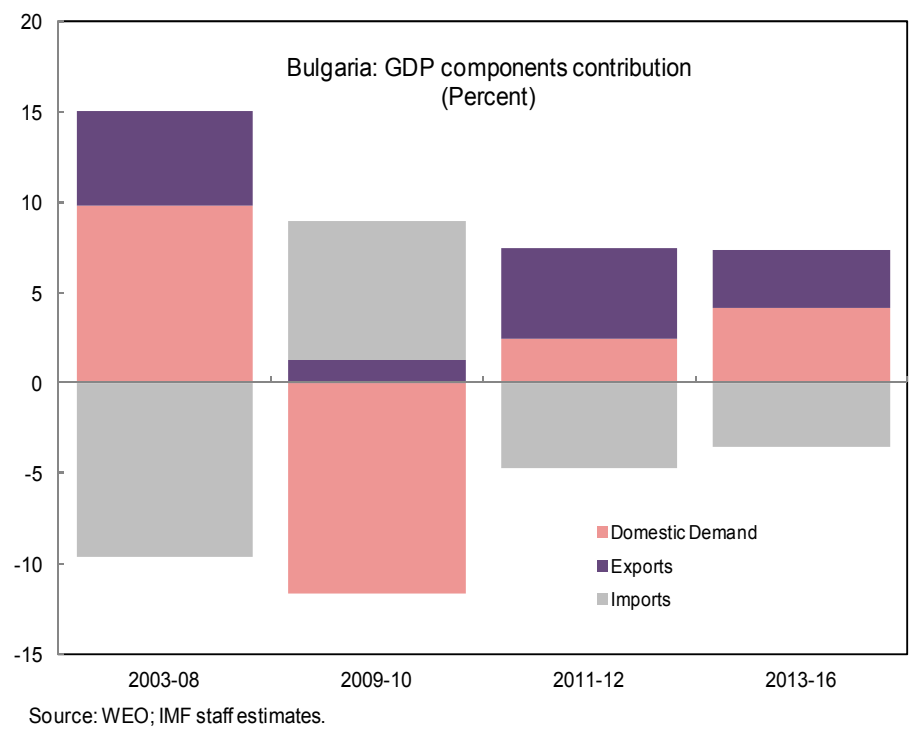
sector reducing its debt burden, external indebtedness should decline further. Higher food and fuel prices are projected to bring average HIPC inflation to $4 \frac{1}{4}$ percent in 2011, before falling back to about 3 percent in 2012. Given the moderate speed of recovery, a quick reduction in unemployment is unlikely.

\section{Medium-term growth is expected to be broader-based but more moderate than} before the crisis (Tables 2, 3). Growth is rebalancing between the domestic and external sectors, building on gains in export market share and improved competitiveness. Real GDP growth is expected to converge to an average rate of about 4 percent over the medium term, allowing real GDP to regain its 2008 peak in 2012 and the output gap to close by 2016 . Still by 2016 , per capita income levels would only be 40 percent GDP of the euro area average and over the longer-run, structural bottlenecks and population aging could constrain growth potential.

11. External vulnerabilities remain high. Despite the current account correction, the increase in gross international reserves since end-2008, and the large portion of intercompany debt in the external debt burden, vulnerabilities remain (Appendix I). Bulgaria's external debt is still significant, and generates a relatively high total financing need of about $251 / 2$ percent of GDP for 2011 (Appendix Table I.1). About 231/2 percent of GDP reflects the rollover of private sector debt, including parent bank support of just over 3 percent of GDP. Moreover, international reserves in excess of the minimum coverage required under the currency board, 
have fallen from 28 percent of total deposits at end-2008 to 22 percent in April 2011, reflecting in part the drawdown of the fiscal reserve to finance the deficit. ${ }^{1}$

12. Risks are tilted to the downside. Given the significant presence of foreign-owned banks in Bulgaria, financial spillovers from tensions in the euro area periphery could negatively impact the financial system, including by causing parents of euro area periphery banks to accelerate deleveraging and eroding confidence. In such circumstances, the anticipated recovery in domestic demand would likely stall and exports would be negatively impacted (exports to the euro area periphery comprise just under 10 percent of total exports), especially if growth in Western Europe were also to falter. In this context, Bulgaria's international and fiscal reserves constitute critical buffers to help counter such a shock. Barring adverse shocks, growth has however the potential to be higher than currently forecast, if exports surprise, confidence improves to allow consumption to revive strongly, or if EU funds absorption exceeds expectations. Such a strengthening in demand, if accompanied by a return of large scale capital inflows, could test the current account correction.

\section{Authorities' Views}

\section{The authorities broadly agreed with the assessment but saw greater upside} potential. They saw domestic demand recovering more quickly in 2011 given steps to improve EU funds absorption and strength of exports. On-going structural reforms are expected to lift potential growth in the medium-term. With respect to the regional risks, European-IMF financial assistance to the euro area periphery was seen as the first line of defense to contain external risks, although reserves were seen to be adequate to counter shocks.

\section{Policy Challenges: Managing Risks While Reinvigorating Growth}

Having demonstrated its ability to adjust rapidly, the challenge is to bolster longer-term growth prospects while also sustaining Bulgaria's resilience to shocks. Doing so would reinforce the already strong $C B A$ as the bridge to eventual euro adoption. Increasing fiscal, and maintaining financial sector, buffers will be essential to enhancing capacity to counter potential shocks, including from the euro area periphery. Policies to accelerate on-going structural reforms, make spending more supportive of growth and sustainable over the longerrun, and safeguard financial system soundness would strengthen economic fundamentals and aid smoother convergence.

\section{A. Structural Reforms: Reigniting the Reform Momentum}

14. Bulgaria's competitiveness is improving. Despite some appreciation over recent years, the CGER-valuation range, and export performance suggests the real exchange rate is

\footnotetext{
${ }^{1}$ Ninety percent of the fiscal reserve is deposited at the central bank, and recorded as international reserves.
} 
broadly in line with fundamentals (Box 2). Wage growth had moderated in the face of rising unemployment, and is now broadly in-line with productivity growth (Figure 4). Moreover, National Account based wage data suggests the gap with productivity growth over the period of accession has been less than that suggested by less reliable high frequency survey data.

\section{Stepping up convergence and} job creation will require accelerating on-going structural reforms to boost competitiveness and growth. The Global Competitiveness Report and the World Bank Doing Business Indicators point to infrastructure, education, technology adaption, burdensome administrative procedures, and judicial inefficiencies as

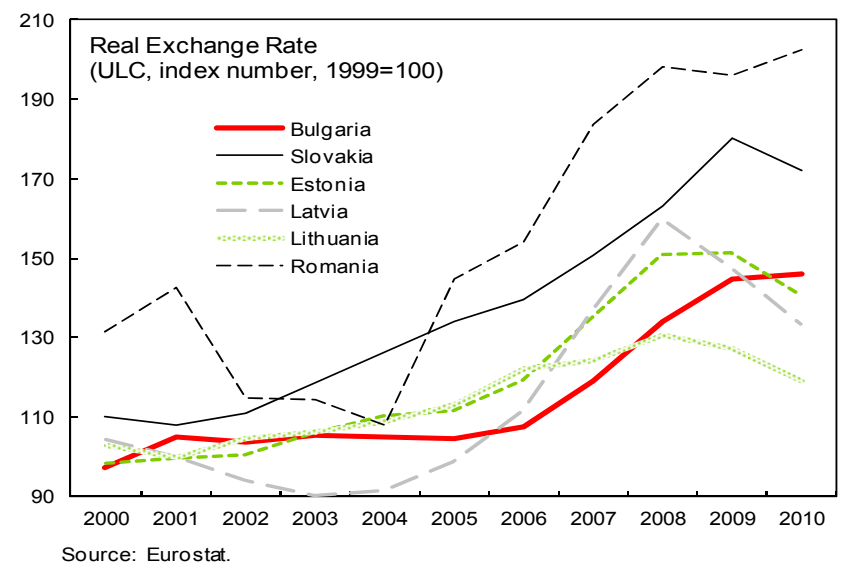
major challenges. Recent scores on the World Bank's Worldwide Governance Indicators and Corruption Perception Indices also suggest that governance and corruption remain a challenge. The new National Reform Program (NRP) appropriately identifies reforms aimed at amplifying competitiveness by increasing the returns to investment in export-oriented industries.

World Bank Doing Business 2011

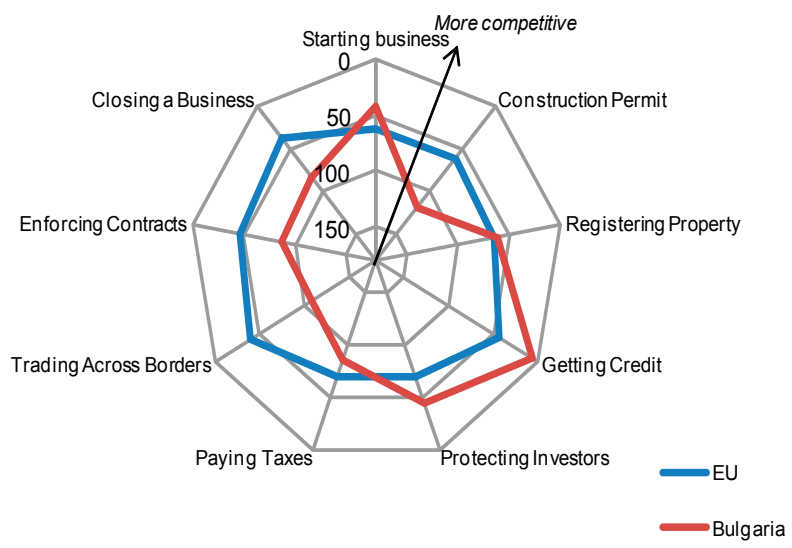

Global Competitiveness Index 2010-11

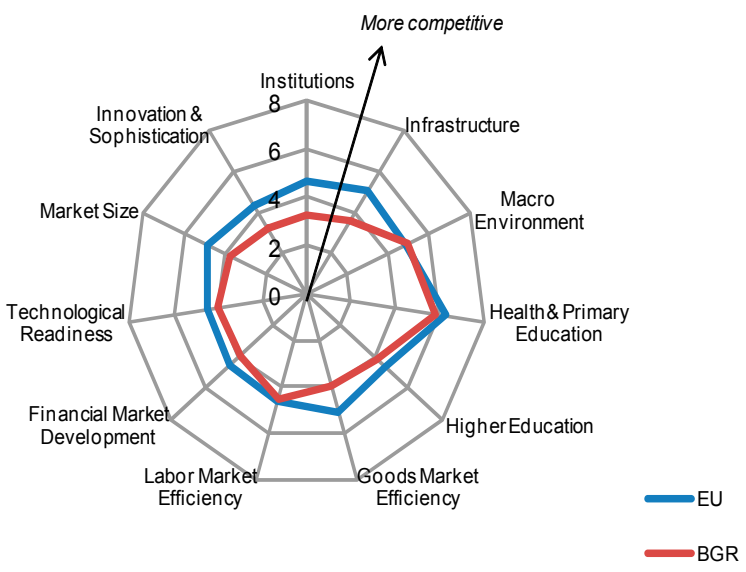

Source: World Economic Forum; World Bank.

\section{Increased labor productivity and better skills matching will help lift growth}

prospects. The NRP rightly identifies the greatest potential for productivity gains in young low skilled unemployed where a skills mismatch is preventing their hiring into vacancies. Job placement services and targeted vocational training programs are being scaled-up using EU social funds to tackle unemployment in the near-term. Long-term youth unemployment will also need to be addressed through active coordination of tertiary and vocational education with employers' needs (especially in tradeables sectors) and apprenticeships. Social security 
contributions also need to be made compatible with more flexible working arrangements to encourage participation.

17. Efforts to reduce the administrative burden can be replicated across all levels of government. Bulgaria is set to achieve its 2012 goal of reducing the administrative burden on firms by 20 percent, based on reforms at the central government level. However, municipal registration, licensing, and permit requirements remain burdensome. A universal internet-based system could reduce compliance costs, increase transparency and help reduce corruption. Contract enforcement at all levels could benefit from simplification of the rules, training of municipal authorities, and judicial reform.

18. Reducing bottlenecks to EU funds absorption will be critical to improve the coverage and quality of infrastructure (Box 3). With World Bank, EBRD and EIB assistance, project preparation capacity is strengthening. Within the last year, controls have been streamlined, verification controls and audit strengthened, while coordination barriers across government agencies are being tackled. Proposed amendments to the Public Procurement Act will streamline the tendering process for EU-funded projects. These reforms should help unleash EU funding for infrastructure and improve its predictability. The proposed restructuring of the railway sector, supported by the World Bank, can modernize Bulgaria's outdated rail network and enhance regional connectivity to facilitate trade.

\section{Authorities' Views}

\section{Reducing unemployment by improving labor force quality and increasing $\mathbf{E} \mathbf{U}$} funds absorption are the main priorities. So far, the administrative reforms implemented have contributed to a substantial increase in EU funds absorption, lending confidence in the ability to meet the targeted doubling of the absorption rate in 2011. By making more effective use of EU social funds, training and employment opportunities for more than 100,000 workers have been created. The amendments to the labor code in Parliament envisage greater flexibility for temporary and distance work. Moreover, they are confident the comprehensive reforms in the NRP combined with Bulgaria's competitive wage levels, will lead to more robust and sustainable medium-term growth and ultimately faster income convergence. 


\section{Box 2. The Real Effective Exchange Rate (REER)}

The external adjustment continued in 2010, reducing the current account deficit below its projected medium term underlying value. The sudden stop in capital inflows - which peaked at 42 percent of GDP in 2007-has largely corrected the absorption gap through a sharp decline in domestic demand that took the current account deficit close to balance in 2010. A gradual recovery in economic activity in coming years would widen the current account deficit somewhat (Table 4).

Overall, CGER-type estimates suggest that the REER is broadly in line with fundamentals, which seems consistent with the rapid recovery in exports. While the REER has appreciated over the last years, the CGER-valuation range suggests that it is not misaligned. Bulgaria's exports market shares in the EU-which more than doubled since 2000 - also suggests that competitiveness has not hampered the export recovery that began in 2009 .

\section{Exchange Rate Assessment - Macrobalance Approach} (In percent of GDP, unless otherwise indicated)

\begin{tabular}{ll}
\hline & Indicators \\
\hline Current account norm & -3.4 \\
Underlying current account & -3.3 \\
Gap & -0.1 \\
REER required adjustment (in percent) & 0.3 \\
Memorandum & \\
Current account elasticity to REER & -0.3 \\
\hline
\end{tabular}

The macroeconomic balance approach suggests that the REER is slightly undervalued. The underlying saving investment balanceestimated as the current account balance net of EU capital transfers at the end of the projection period - is compared against the current account norm calculated through CGER-type methodologies. This suggests that the real exchange rate is undervalued by about $1 / 4$ percent.

The external sustainability approach points to a somewhat larger REER undervaluation. This approach - which assesses the adjustment needed to stabilize the international investment position (Table 8) at its medium term value, a negative 70.9 percent of GDP under current projections - suggests that the REER is undervalued by 3.4 percent.

The equilibrium real exchange rate methodology points to a small overvaluation. This method compares the estimation of the equilibrium REER based on the average value of fundamentals during the last 10 years against the estimation based on the current value of fundamentals, and finds that the real exchange rate is overvalued by 3.9 percent.

Exchange Rate Assessment - External Sustainability (In percent of GDP, unless otherwise indicated)

\begin{tabular}{lc}
\hline & $\begin{array}{c}\text { IIP target (in } \\
\text { percent of GDP) } \\
-70.9\end{array}$ \\
\hline Current account norm & -4.4 \\
Underlying current account & -3.3 \\
Gap & -1.1 \\
REER required adjustment (in percent) & 3.4 \\
Memorandum items & \\
GDP growth (in percent) & \\
GDP deflator (in percent) & 4.0 \\
\hline
\end{tabular}


Box 3: EU Funds Absorption: Maximizing the Potential

EU funds allocated to Bulgaria for the period 2007-13 amount to $€ 9.4$ billion, or about 26 percent of 2010 GDP, excluding about $€ 2$ billion in national co-financing

Disbursements only reached 10 percent of the total by end-2010. The absorption rate was very low compared to Latvia and Lithuania - the highest ranked in the EU in terms of absorptionwhere some 30.0 and 29.0 percent had been disbursed between 2007-10.

The government aims to increase absorption to $€ 770$ million in 2011 , which is equal to the total absorption for 2007-10. Effective absorption has the potential to provide a substantial boost to the economy. Estimates suggest the efficient use of the social and cohesion funds could boost potential GDP growth by $0.30-1.43$ percent per year in 2007-13, rising to about 3 percent in 2017-25.

The low rate of absorption in Bulgaria reflects various weaknesses. Compliance reports and control systems did not initially observe EC requirements. Cumbersome application and procurement procedures impeded project implementation. Beneficiaries lack capacity for timely preparation of the projects and face long payment lags. There are also problems with tender procedures, expropriation procedures for land as well as environmental estimates, and financial irregularities.

In the second half of 2010, absorption accelerated. This reflected the high priority assigned by the government, various administrative reforms, as well as the appointment of a special EU Funds Minister to improve coordination. To build on this progress, the proposed Public Procurement Law could be complemented by reforms that establish partnerships with private parties involved in the process, address weaknesses in the application and implementation process especially at the municipal level, speed-up ex-ante controls in bidding documentation, and shorten the preparation phase of large infrastructure and environment projects.

\section{B. Fiscal Policy: Growth-Enhancing Adjustment}

\section{Fiscal policy in 2011 is focused on securing a rapid exit from the EU excessive} deficit procedure (EDP) and ensuring low public debt (Appendix I). The 2011 budget deficit targets a continued reduction in the deficit to 2.5 percent of GDP (ESA 95 terms). This target will help preserve the fiscal reserve, provide a margin with respect to the Maastricht deficit ceiling, and will also counter inflationary pressures. Although budget execution was in line with the first quarter plan, profit taxes and social security contributions exhibited some shortfalls. To ensure a timely exit, it will be important to sustain ongoing efforts to counter tax and social security evasion and resist pressures for generalized wage and pension hikes. Targeted increases in minimum social benefit payments would more effectively protect vulnerable groups from inflation pressure and could be financed through the budget contingency. Should expenditure cuts prove necessary during the year, every effort should be made to protect growth enhancing capital outlays while controlling new commitments. In the event revenue over-performs, the additional funds should be saved to boost the fiscal reserve.

\section{Fiscal consolidation is being anchored on Bulgaria's medium-term objective of} securing a small budget deficit (Tables 5a, b). The revised medium-term fiscal objective of a 0.6 percent deficit (previously a 0.5 percent surplus) is still consistent with a continued decline 
in debt. The Convergence Program (CP) anticipates reducing the fiscal deficit to achieve this target by 2014. This entails a total adjustment of about 2 percent of GDP between 2012 and 2014, although under more conservative assumptions regarding revenue buoyancy, the adjustment could be about $1 / 2$ percent higher. The pace of adjustment serves to safeguard the fiscal reserve without placing an undue drag on the recovery but aiming for some safety margin with respect to the consolidation target would address the risks of shortfalls. Depending on the pace of recovery after 2014, fiscal policy should pursue a more ambitious objective of a small surplus to provide a greater cyclical cushion relative to the Maastricht deficit ceiling.

22. The consolidation hinges on continued expenditure restraint. Against the backdrop of stable tax system, the CP envisages a continued real contraction of spending to the lower levels of post-boom revenue. The contraction is largely achieved through the imposition of tight spending ceilings, including the extension of the wage and pension bill freezes through end-2012. In this context, the new ceilings on government liabilities will be crucial to ensure control of spending commitments.

\section{Measures to further increase spending efficiency would improve the quality and} durability of the consolidation effort. Going forward, strong spending control should be accompanied by reforms that create space within the tighter budget envelope to improve spending effectiveness, enhance service quality, and free resources for growth-enhancing education, and capital outlays. The priorities include:

- Health care: Recent reforms in drug procurement should contribute to improved cost control, enhanced access, and reasonable pricing of pharmaceuticals. Responsibilities between the Ministry of Health and the National Health Insurance Fund are being streamlined. These reforms should be complemented by steps to rationalize the hospital sector (reducing overcapacity) and improve information systems so reforms translate into better healthcare access and outcomes.

- Public administration: To reduce its overly large public sector, the central government shed 12 percent of its workforce by closing obsolete agencies and reforming customs and security forces since mid-2009. With more cuts expected in 2011, space has been created for the introduction of performance-based remuneration to attract more skilled staff without increasing the overall payroll envelope. The achievements at the central government level need to be expanded to autonomous spending units, particularly municipalities.

- Pensions: The 2010 pension reform yielded 0.6 percent of GDP in savings per year, but an annual deficit of about 4 percent of GDP remains and the contribution-benefit gap will widen further as the population ages and a higher pension accrual rate kicks in after 2016 (Box 4). Therefore, further efforts are needed to make a dent in the sizeable deficit projected post-2016, including further increases in the retirement age and service 
period, linking them to life expectancy, and by anchoring benefit increases to developments in pension contributions.

24. To enhance fiscal policy credibility, the authorities plan to adopt a constitutional deficit ceiling as part of a "Financial Stability Pact." The proposed Pact contains a constitutional deficit ceiling that — at two percent—is set tighter than the Stability and Growth Pact. The Pact also limits expenditures to 40 percent of GDP, and subjects changes in direct taxes to a constitutional majority vote. The pact provides strong backing to Bulgaria's commitment under the Euro Pact Plus. However, the high bar to change direct taxes risks limiting flexibility on the revenue-side to indirect tax rates.

25. A simple and well-designed fiscal rule would reinforce the Pact and provide greater guidance to fiscal policy over the economic cycle. The recent crisis underscored the importance of restraining expenditure during upswings. As the constitutional cap on the spending-to-GDP ratio is unlikely to provide a sufficient guide to policy, the pact should be complemented by a fiscal rule. To this end, a transparent rule linking fiscal policy to a prudent estimate of potential growth, incorporating mechanisms to correct deviations, and creating savings in upswings should be included in the organic budget law (Box 5). The effectiveness of the Pact and new rule would be enhanced by an independent institution that reviews the budget and evaluates reforms.

\section{Authorities' Views}

\section{The authorities maintain strict control over spending and are confident that} reforms would improve spending quality. They underscored the importance of a timely EDP exit to cement their standing within the EU as a country with conservative fiscal policies. The authorities were standing firm against spending pressures and would only re-evaluate space for targeted increases if revenue surprised positively. They were confident that the Pact would receive broad-based support. The constitutional bar for changes in direct tax rates was seen as providing assurance about the stability of the tax regime while sufficient flexibility is retained as indirect taxes would not be subject to the super majority requirement. The authorities plan to formulate a proposal for a fiscal rule by the fall. However, with limited institutional capacity domestically and already strong oversight under the EU semester, the authorities saw little scope for a fiscal council. While acknowledging the need for safeguarding the long-term financial viability of the pension system, they wanted to first evaluate the effects of the recent reforms. 


\section{Box 4: Public Pension Reform}

In face of high and rising spending pressures from Bulgaria's public pension system, the government implemented a pension reform package in fall 2010. At 10 percent of GDP, Bulgaria's pension outlays are high by regional standards. The crisis revealed weaknesses in the social security system with sharply declining contribution collections and a jump in benefit claims. Despite the recovery, the deficit in the public pension system is expected to increase over time given population aging and generous pension entitlements, including early retirement rules and partial wage indexation.

In November 2010, the authorities agreed on a reform package. With IMF technical assistance, the authorities identified possible measures for a pension reform and initiated first steps. The reform package increased the contribution rate by 1.8 percentage points from 2011 and the service requirement for a full pension by four months each year from 2012 until 2020. It also increases the retirement age gradually to 65 years for men and 63 years for women over the next two decades.
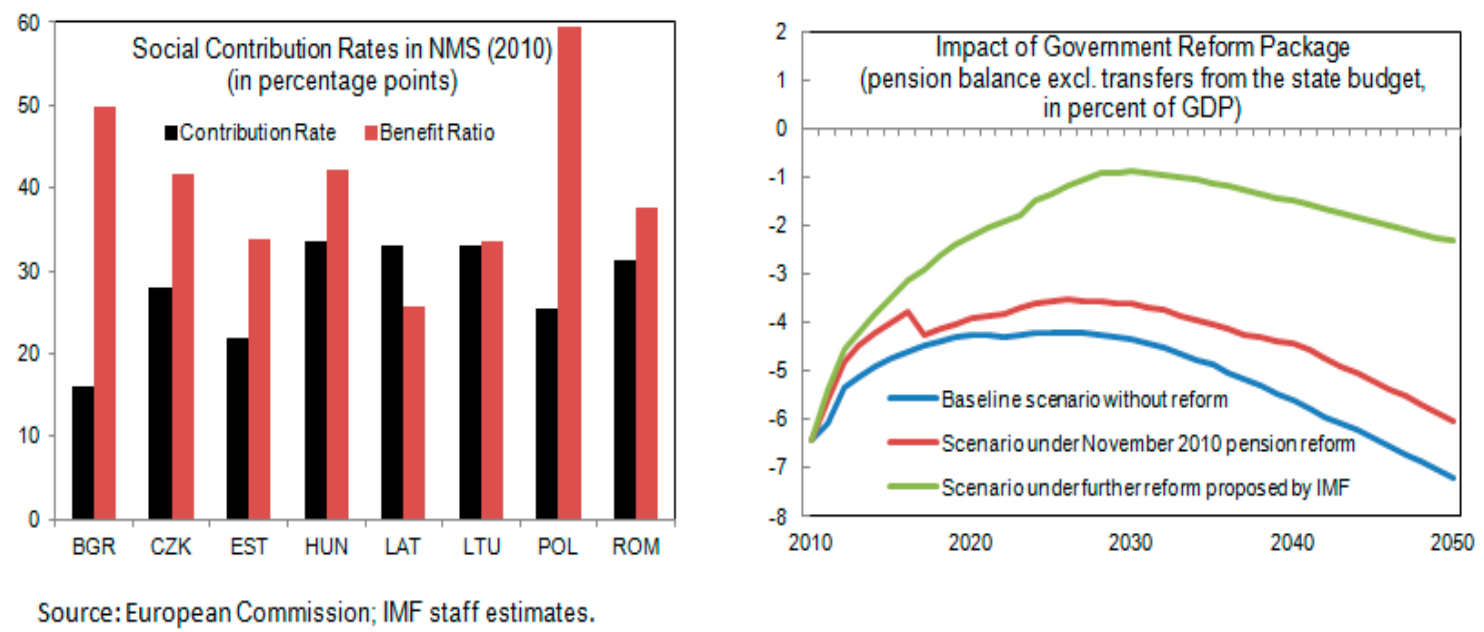

While commendable, more needs to be done to ensure sustainability. In the short run, more ambitious increases in the contribution rate and service requirement should be coupled with tightened controls on disability pension beneficiaries to reduce their abuse. This could reduce the pension deficit by about 1 percent of GDP. In the medium term, an additional 4 percent of GDP could be saved by (i) gradually increasing the retirement age to 66 years and linking it to life expectancy; (ii) a change to a less generous indexation of benefits; (iii) raising second pillar contribution rates; and (iv) harmonizing pension treatment across most professions, including the phase-out of overly generous early retirement pensions. Complementary reforms to remove investment restrictions and develop an annuities market could boost returns on pension savings accumulated under the second and third pillars. 


\section{Box 5: Options for a Fiscal Rule to Complement the Financial Stability Pact}

A fiscal rule could help guide fiscal policy particularly during upswings. As the economy recovers and with the overall deficit and debt low levels, the proposed ceilings in Pact are unlikely to present a binding constraint to guide policy going forward. A supplementary fiscal rule would complement the Pact.

Suitable designs include a growth-adjusted balance rule or an expenditure rule. On one hand, the former presents the most comprehensive framework and prescribes realistic adjustment paths. On the other hand, the expenditure rule gives clear guidance in the budget planning process and is ideally suited to prevent procyclical expansions.

\begin{tabular}{lll}
\hline & Growth-adjusted balance rule & Expenditure rule \\
\hline Advantages & - Strong guidance throughout the cycle & - Clear guidance for expenditure \\
& - Smooth adjustment path towards & budgeting \\
& balance target & - Prevents procyclical expansion \\
& & - Good track record in other countries \\
\hline Disadvantages & - Limited countercyclicality & - No guidance on revenue policies \\
& - Fairly complicated formula & - Difficult calibration \\
\hline
\end{tabular}

Using historical outturns for 2002-10, the growth-adjusted balance rule would have allowed a strong countercyclical fiscal response at the height of the crisis. The expenditure rule would have resulted in the accumulation of higher buffers by preventing the fiscal expansion in the boom years, allowing for a slower pace of consolidation path after the shock hit. Looking forward, each rule would result in low debt and deficits.
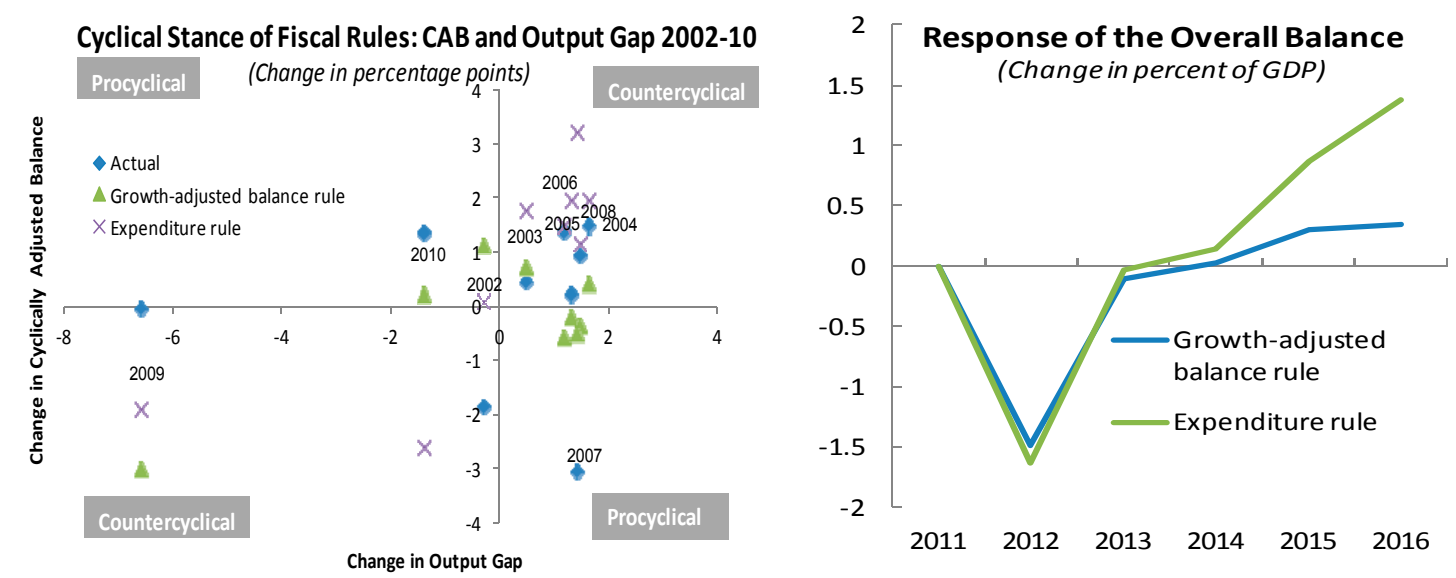

1/ The shock refers to a two standard deviation shock in the output gap. 


\section{Financial Sector: Maintaining Resilience}

27. The banking system, while stable and well capitalized (Tables 6, 7), continues to operate in a challenging environment. The challenges are two-fold. Asset quality remains a key concern particularly given the increase in NPLs against the backdrop of a hesitant recovery in domestic demand that is keeping credit demand, and hence profits that aid potential loss absorption, low. However, in the context of heightened regional uncertainty, financial spillovers and a reversal in parent bank funding are also a risk. In particular euro area periphery banks, which hold $281 / 2$ percent of banking system assets and $251 / 4$ percent

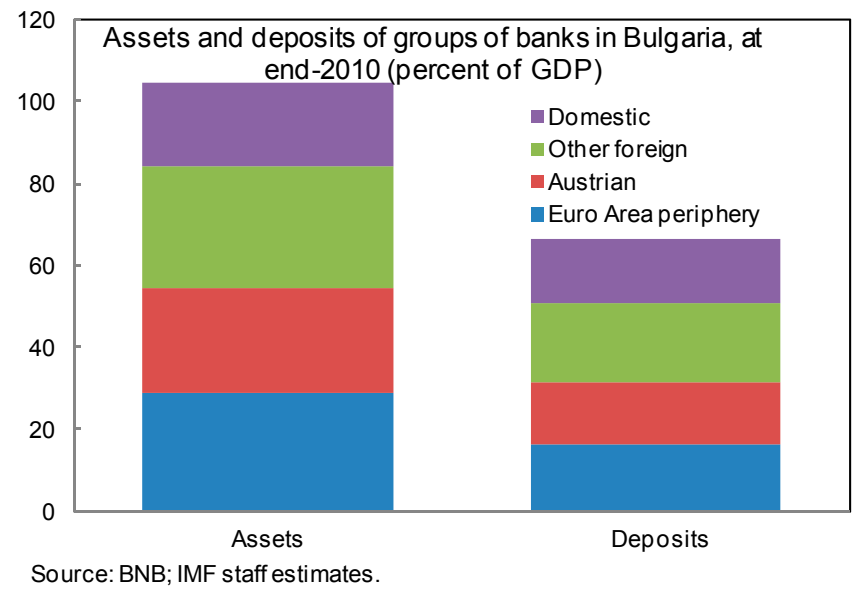
of non-financial corporate and household deposits, are particularly vulnerable to spillovers from tensions in their home country or parent-banks.

28. The deterioration in asset quality is one of the main challenges facing the banking system but existing buffers appear adequate. BNB's estimates suggest NPLs are expected to peak in the later part of 2011 and then gradually decline. The existing levels of provisions, collateral and expected recovery in profits, should allow the banking system to comfortably absorb such losses while maintaining high levels of capital adequacy. Still, a more protracted recovery could delay this decline, while high unemployment and a weak property market pose challenges to the quality of risk exposures to construction, real estate, and small and mediumsized firms.

\section{Improvements in the household and corporate insolvency framework would} strengthen credit growth. So far, weak credit growth largely reflects a lack of demand, as the private sector has paid down debt and has been reluctant to engage in new borrowing despite the reduction in lending rates. As the recovery gathers pace, it will be important that NPLs not constrain the ability of banks to resume lending. High legal fees, uncertainty about the legal process and questionable outcomes from loan recovery are slowing asset workout and risk constraining new lending. Clear criteria for the initiation of insolvency proceedings, expedited court approval of pre-packaged restructuring plans, and priority status to creditors who inject new capital to the rehabilitation process would improve the debt restructuring process.

\section{As the economy recovers, regulatory requirements should remain tight to rebuild} buffers in the banking system. Provisioning requirements and certain risk weights were appropriately eased during the crisis to allow banks to utilize some of their buffers to absorb losses. With the recovery still not firmly established and real estate prices yet to fully stabilize, restructured loans should be closely monitored to ensure appropriate provisioning and collateral 
valuation. As the recovery strengthens, the regulatory easing implemented in the crisis could be gradually reversed. The still conservative Bulgarian regulatory and supervisory regime will facilitate the implementation of the new Basel III requirements.

31. Challenges posed by weaker banks are being firmly addressed. Weaker banks continue to be closely monitored via more frequent data reporting and supervisory visits. The supervisory colleges under the European Financial Stability Framework, has significantly improved co-operation and information flows. A sale of a Slovenian-owned bank was just completed, and a takeover of a mainly Irish-owned bank is in the pipeline. The recent crisis did not result in any liquidations or recourse to the Deposit Insurance Fund (DIF). However the legal framework for bank resolution should be comprehensively reviewed to determine whether the BNB would have sufficient tools to address any potential bank resolutions.

\section{The loan-to-deposit ratio of the system has improved but remains high for some}

banks. Reflecting the strong growth in deposits over the past year, the ratio of liquid-assets to short-term liabilities has risen.

Nevertheless, many foreign-owned banks continue to operate with comparatively high loan-to-deposit ratios. As demonstrated in 2009, the on-going support pledged by parents is crucial to address potential liquidity and capital needs. While all banks currently exhibit a CAR above 12 percent, the $\mathrm{BNB}$ continues to receive assurances from all parents that they would provide the capital and liquidity required to ensure banks

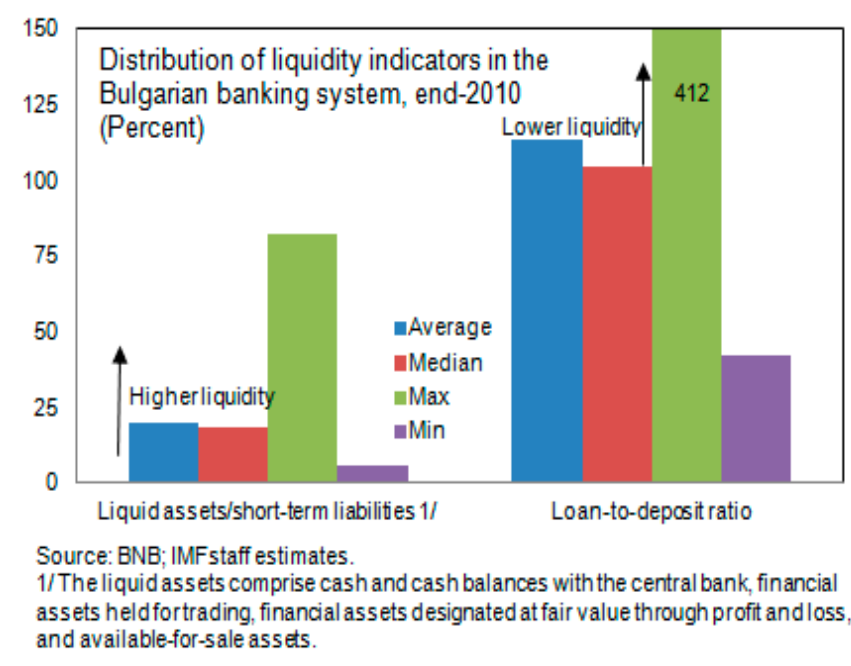
are well-equipped to address potential needs. Moreover, in addition to reserve requirements, banks are required to have a 15 percent coverage ratio of deposits from credit institutions, retail, and corporate customers by liquid assets, which also provide a buffer. Even in the event parent funding were to become limited, gross international reserves in excess of the minimum coverage required under the CBA represent 22 percent of banking system deposits, providing a further backstop.

33. Contingency planning remains essential given regional uncertainty. The authorities are actively participating in discussions on the design of a soon-to-be issued European contingency planning framework and continuously improving their stress testing methodologies. The BNB and MOF are working together within the existing contingency planning framework to prepare for the envisaged EU-wide changes. 


\section{Authorities' Views}

\section{The authorities see the banking system as well-equipped to deal with the}

vulnerabilities. The BNB's stringent stress tests demonstrate the adequacy of existing buffers. The authorities stressed the importance of avoiding premature tightening when credit demand is weak, and especially as the regulatory regime remains very conservative by international standards. They also have an array of tools to deal with sudden liquidity risks. Banks' required reserves with the BNB provide an important line of defense. Solvent banks can also temporarily draw on BNB liquidity subject to haircuts on eligible collateral according to the BNB Law and Ordinance No. 6. Even though such loans may not exceed the limit fixed by the CBA, reserves are currently well in excess of this floor and can offer a sizeable backstop to the banking system. Other back-stop mechanisms can also be used, including tools to take over a bank and sell it in line with the bank resolution framework. Moreover, their experience from the 1996/97 banking crisis, and with their crisis preparedness frameworks well tested by the events of 2008, the authorities are well equipped to act swiftly. Improvements to the bank resolution and contingency planning framework would be made in the context of on-going initiatives at the EU level.

\section{Rebuilding Reserves and Fiscal Financing}

\section{The CBA is the bridge to eventual euro adoption. It has been a pillar of} macroeconomic stability in Bulgaria since inflation stabilization in the late 1990s, offering a credible anchor to the economy as Bulgaria entered the European Union. Moreover, during the financial crisis, the economy has shown its ability to adjust rapidly under the policy limits imposed by the CBA, and confidence in the monetary regime remains high. Consequently, the $\mathrm{CBA}$ is the right instrument to guide policies until eventual euro adoption.

\section{High international reserves support the CBA, and bolster its ability to sustain} potential shocks. The fiscal reserve, comprising one-fifth of total external reserves, played a critical role in allowing Bulgaria to weather the recent crisis so well, underpinning confidence in the CBA. High reserve buffers provide Bulgaria extra resources to address shocks and ensures it is comfortably placed to meet the upcoming bond amortization payments (Eurobond repayments of about $€ 1$ billion in both 2013 and 2015). Recent drawdown of the FRA to finance the fiscal deficit has reduced reserve coverage to below 180 (at end-April 2011) from 200 percent of reserve money (at end-January 2010). Given the external risks, the fiscal reserve should now be preserved and rebuilt.

\section{A Eurobond issue in 2011, complemented by privatization and domestic debt} issuance, would quickly rebuild fiscal reserves. A 'Eurobond' issue offers the greatest potential to quickly increase reserve coverage ratios at a reasonable cost given Bulgaria's low debt, favorable spreads and sovereign ratings, and the current low interest rate environment. If market conditions prevent this, the authorities should consider increasing domestic bond issuance as long as liquidity conditions are favorable. The renewed push for privatization planned for 2011 would not only 
enlarge the role of the private sector, but would also yield complementary resources to replenish the fiscal reserve. To make the government's debt management strategy more effective, existing issues should be consolidated, benchmark issues established, and the system of primary dealership streamlined to enhance market liquidity, as recommended by recent IMF technical assistance.

\section{Authorities' Views}

38. The authorities have not included a Eurobond issue in their $\mathbf{2 0 1 1}$ fiscal financing strategy. They concur with the staff about the importance of the financial buffer during the recent financial crisis, and plan to rebuild the fiscal reserve over time. However, they are planning steps to tap the Eurobond market in 2012, as they consider their liquidity buffers adequate for 2011 .

\section{Staff Appraisal}

39. The export-led recovery continues but faces headwinds from rising inflation and uncertainty. Exports have rebounded above pre-crisis levels. However, consumption remains weak amid increases in inflation and heightened regional uncertainty. Staff expects moderate real GDP growth in 2011, with risks tilted to the downside. Looking ahead, real GDP is expected to recover to its pre-crisis levels by 2012 but reach its potential only in 2016 with more modest growth than before the crisis.

\section{Nonetheless, in the context of greater uncertainty regarding the euro area} periphery, the economy remains vulnerable to external shocks. The external debt burden is still significant and it generates a relatively large re-financing need, including for the financial sector. The linkages of the financial sector to the euro area periphery are a source of risk. Tensions could spill over into Bulgaria, including by causing euro area periphery banks to deleverage more quickly, and eroding confidence. This would have the potential to de-rail the recovery.

\section{Preserving and rebuilding international and fiscal reserves will help bolster} defenses to counter such risks. The fiscal reserve played a critical role through the crisis, serving both to finance the deficit and underpin confidence in the CBA. While all banks are well capitalized and the system is liquid, it would be important in light of the risks to further bolster potential backstops. The fiscal reserve should now be preserved and quickly rebuilt through more proactive debt issuance and privatization. High reserve buffers provide Bulgaria extra resources to address shocks and ensures it is comfortably placed to meet the upcoming bond amortization payments.

42. Crisis preparedness and contingency planning remain essential given the regional uncertainty. While the financial system has proven resilient and capital and liquidity appears ample, in the current environment, continued close monitoring of banks and coordination with home supervisors and the Ministry of Finance will be needed to contain risks. 
43. While banking system indicators have improved over the last two years, deteriorated asset quality also calls for continued vigilance. Capital indicators remain strong, but the level of NPLs remains high, and profits have declined amid weak credit demand. With recovery not yet firmly established, restructured loans should be closely monitored to ensure appropriate provisioning and collateral valuation. Still current profits, existing provisions, collateral, and capital appear adequate to absorb potential losses. As the recovery gathers pace, the regulatory easing implemented in the crisis could be gradually reversed. Improvements in the corporate and household debt resolution framework would strengthen credit growth.

44. Sustained structural reforms are needed to jump-start job creation and income convergence. The NRP appropriately targets measures aimed at reducing the huge skills mismatch, especially in tradeables sectors. Welcome progress has been made in improving product markets and addressing bottlenecks to EU funds absorption. These reforms need to be replicated at all levels of government, and judicial and governance shortcomings addressed to enhance Bulgaria's attractiveness for foreign direct investment.

\section{Exit from the EDP and the proposed Financial Stability Pact underscore} Bulgaria's commitment to prudent fiscal policies. Every effort should be made to meet the 2011 deficit target and resist spending pressures. Over the medium-term, a safety margin with respect to the new medium-term objective would address revenue underperformance risks. While continued imposition of tight budget ceilings has yielded commendable efficiency gains in recent years, deeper reforms in health, public administration, and pensions are needed to improve the quality of public spending and to address pressures related to aging.

Complementing the Financial Pact with a rule linking fiscal policy to a prudent estimate of potential growth would help restrain expenditure in upswings.

\section{It is proposed that the next Article IV consultation with Bulgaria will be held on} the standard 12-month cycle. 
Figure 1. Bulgaria: Real Sector Developments

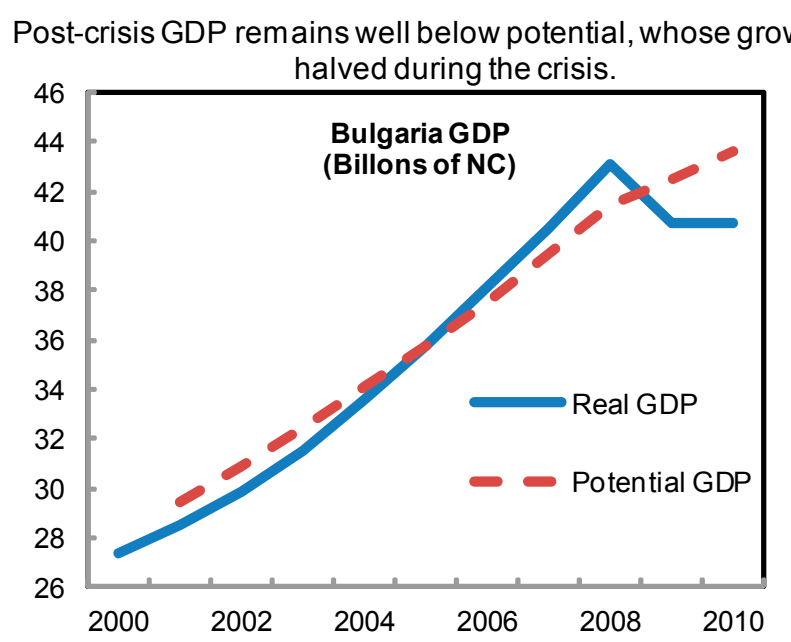

The recovery has been export-led...
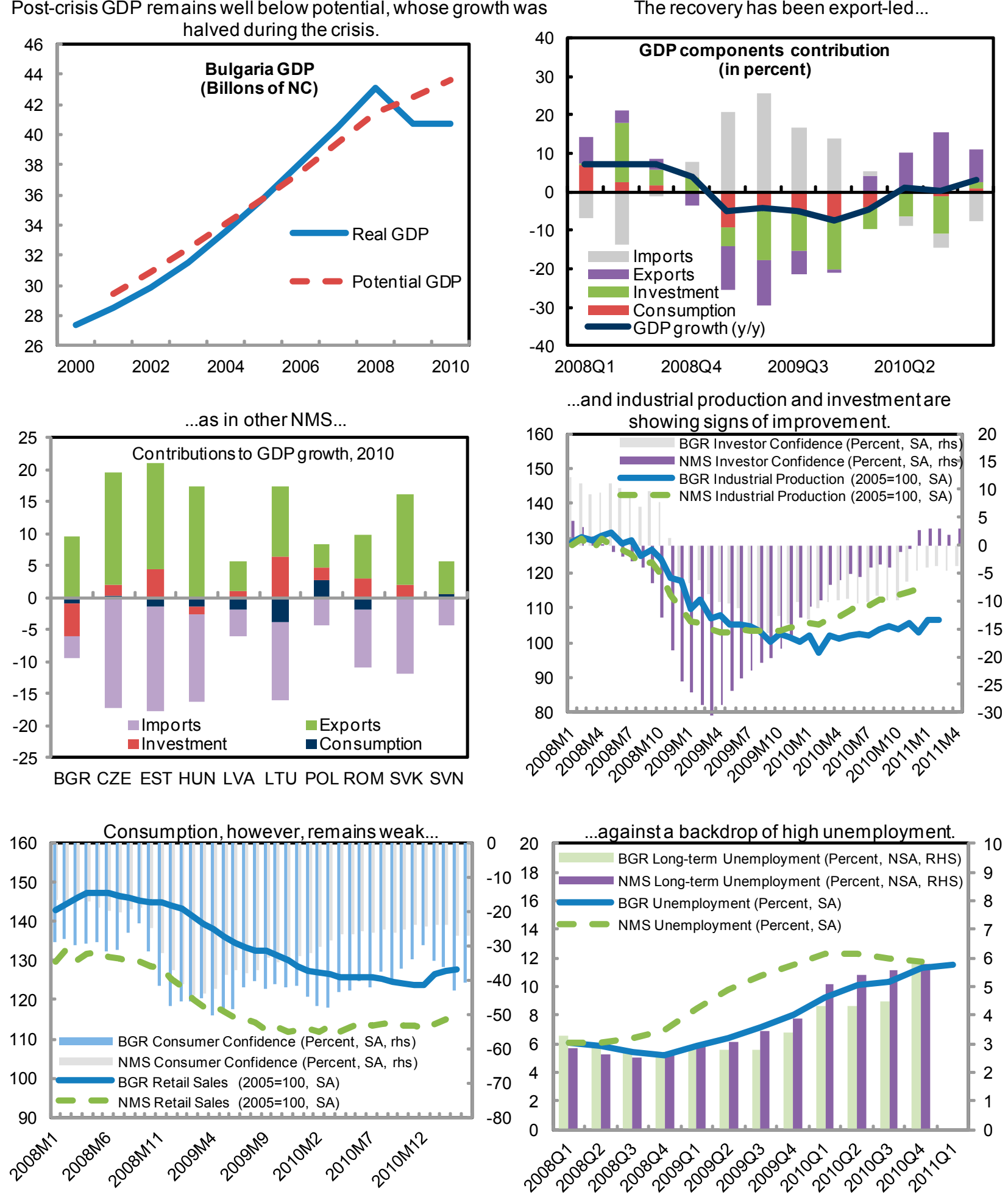

Source: Eurostat, Haver; WEO; IMF Staff estimates. 
Figure 2. Bulgaria: External Sector Developments

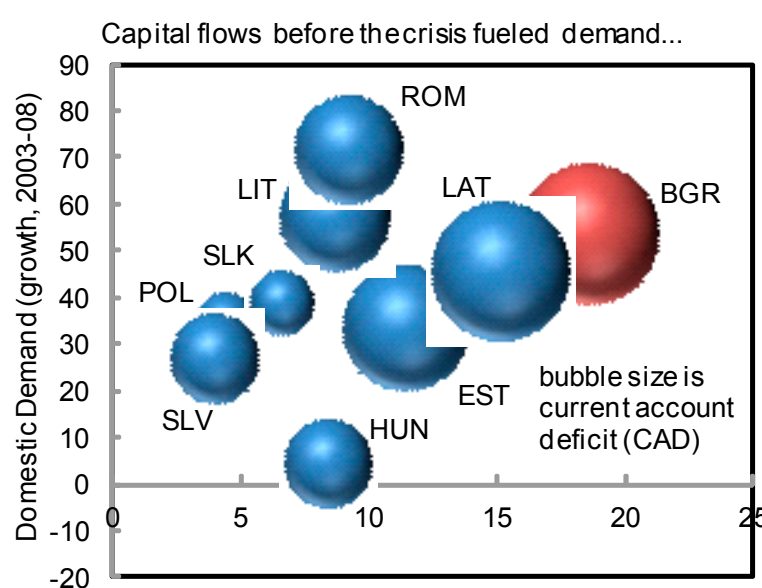

Capital Flows (percent of GDP, 2003-08)

...but Bulgaria's current account adjusted swiftly

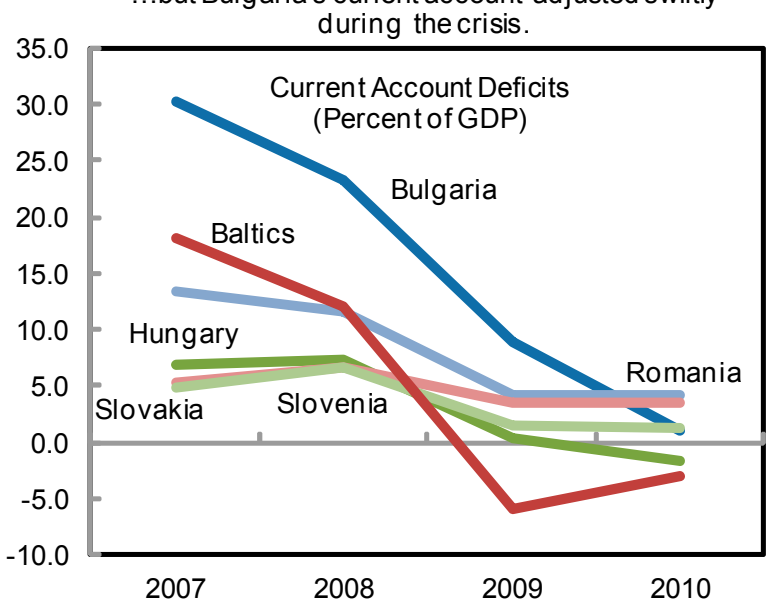

...aiding exports to increase market share.

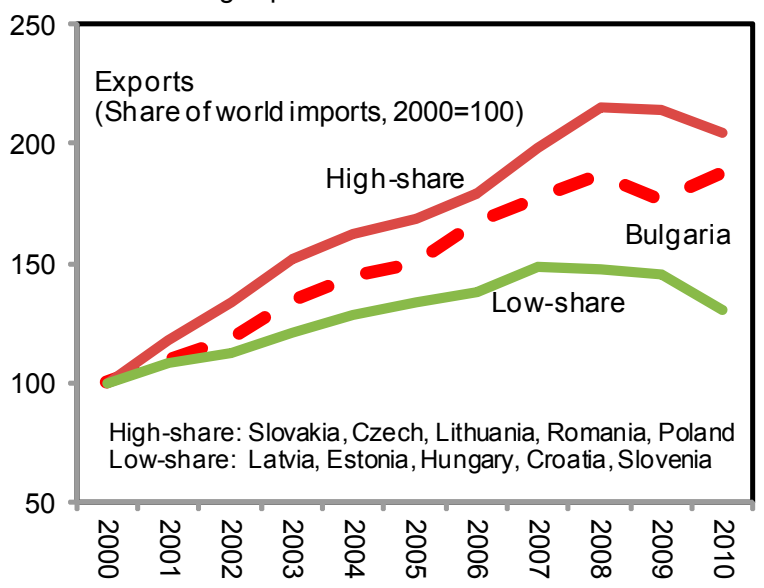

...raised current account deficits and put pressure on the RER...
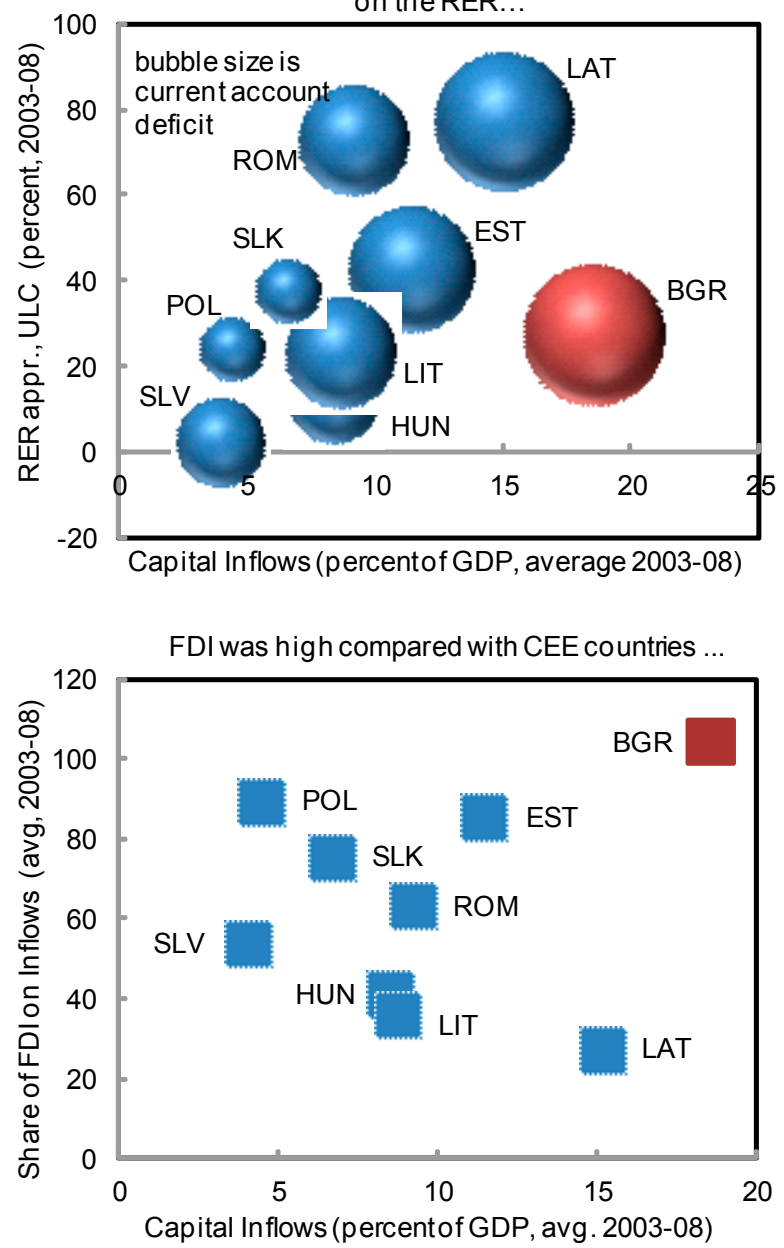

External debt is high, but largely comprising intracompanylending.

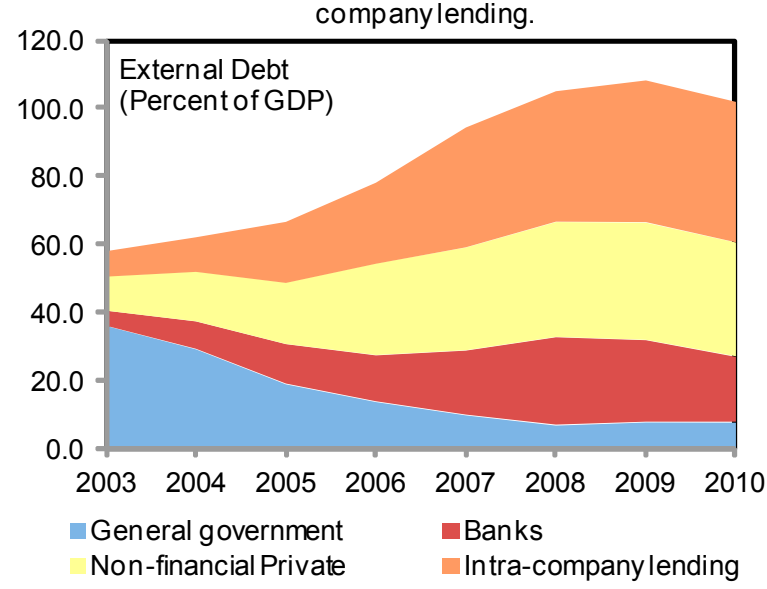

Source: Bulgaria Authority data; IMF staff estimates. 
Figure 3. Bulgaria: Inflation and Monetary Developments

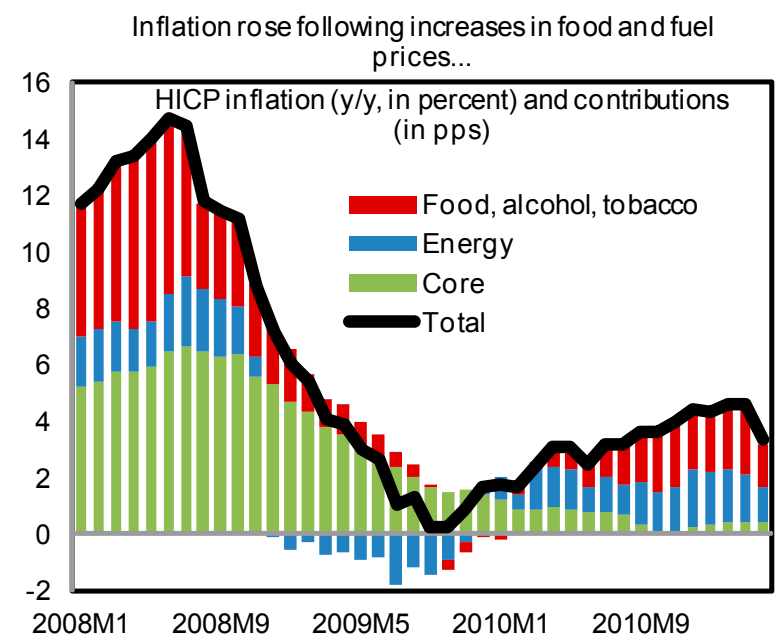

Credit remained flat in 2010.

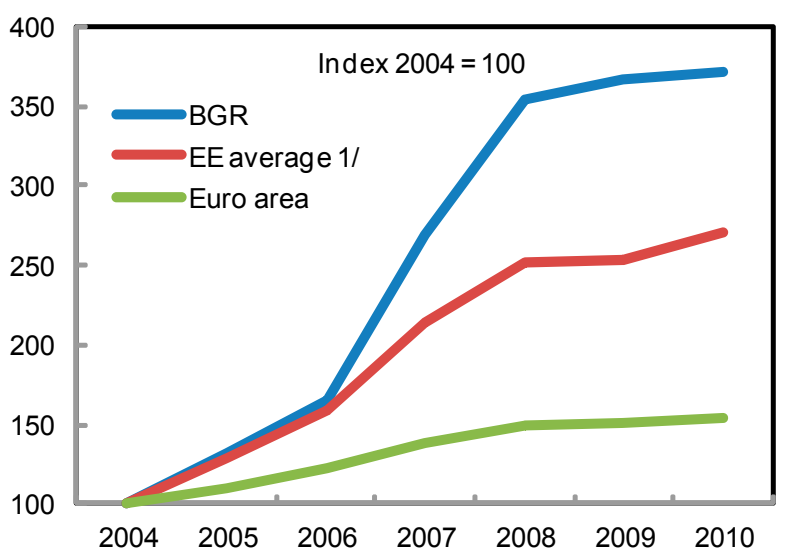

...despite a fall in lending rates, especially in leva...

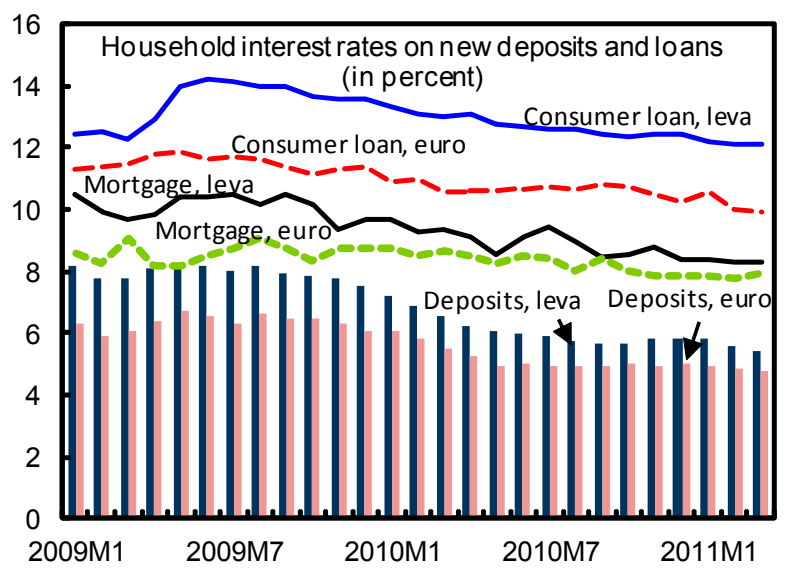

...as in the rest of the region.

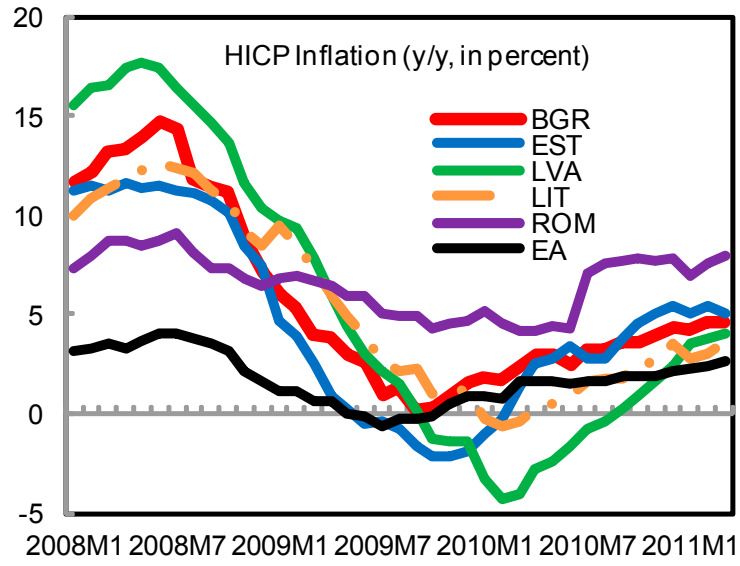

Credit to households fell.

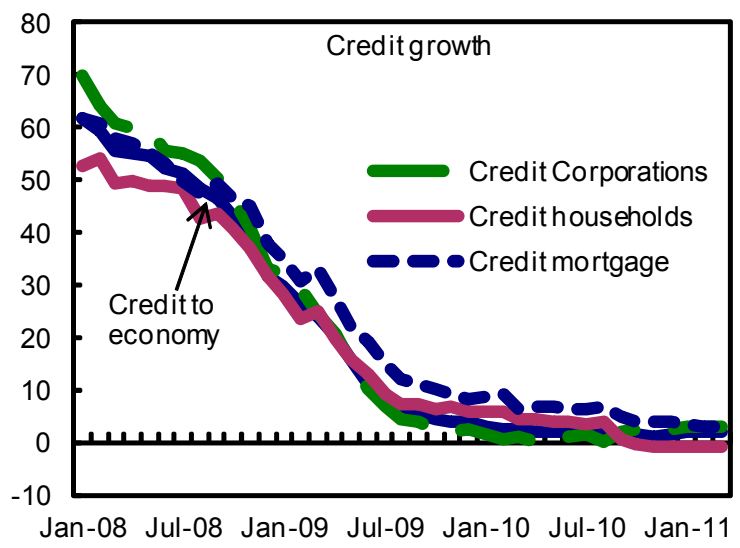

...but deposits kept growing

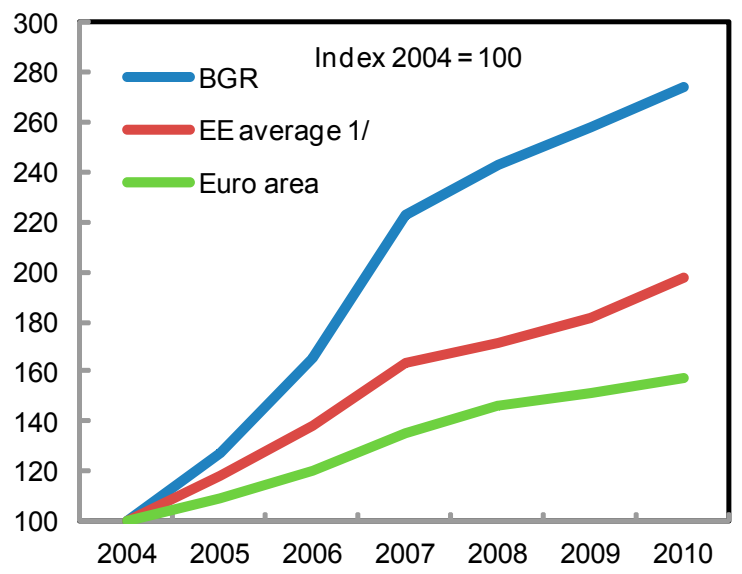

Source: BNB; Eurostat; and IMF staff estimates. 1/ CZE, EST, HUN, LVA, LTA, POL, ROM 
Figure 4. Bulgaria: Labor Market Developments

UE doubled during the downturn..

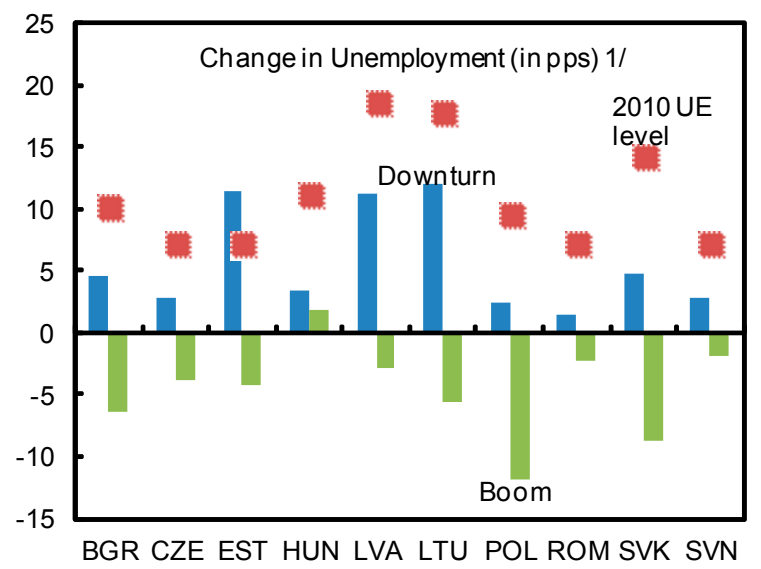

...severely impacting the youth, and risking further increases in long-term unemployment.

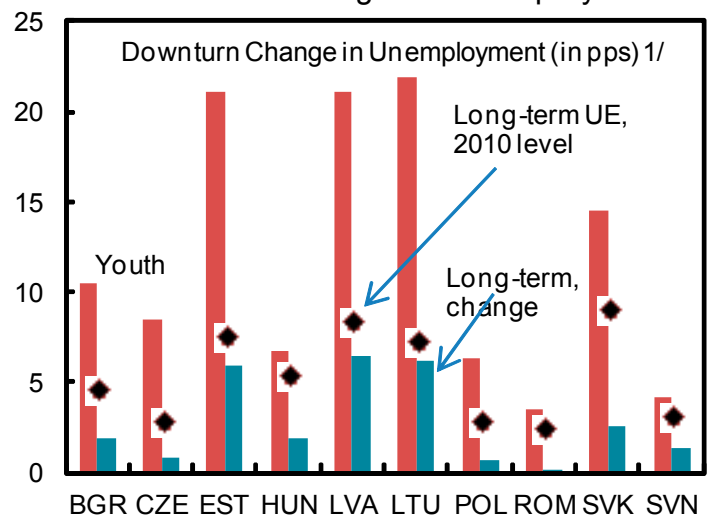

Real wage growth has broadly followed productivity.

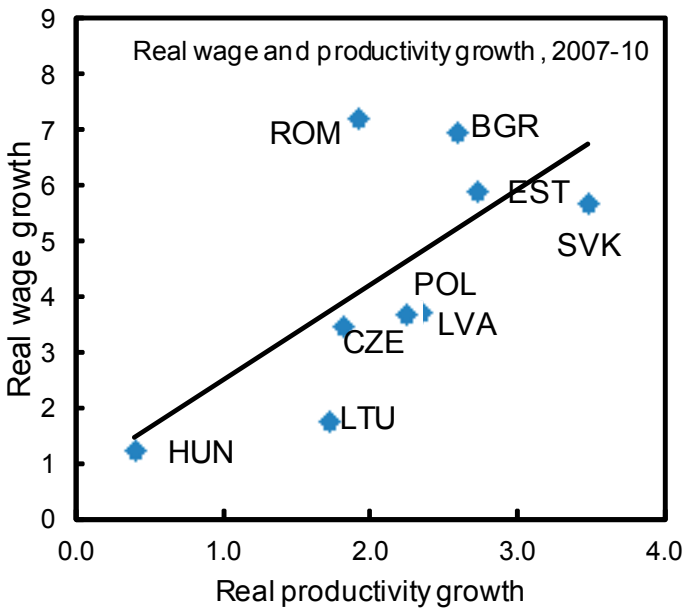

...especially in construction, manufacturing, and services...

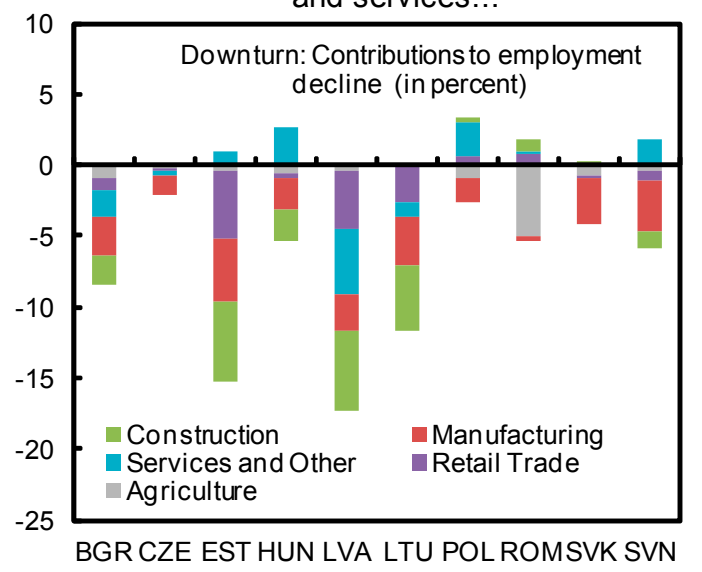

Nominal wage growth is slightly higher than the region, but wage levels remain the

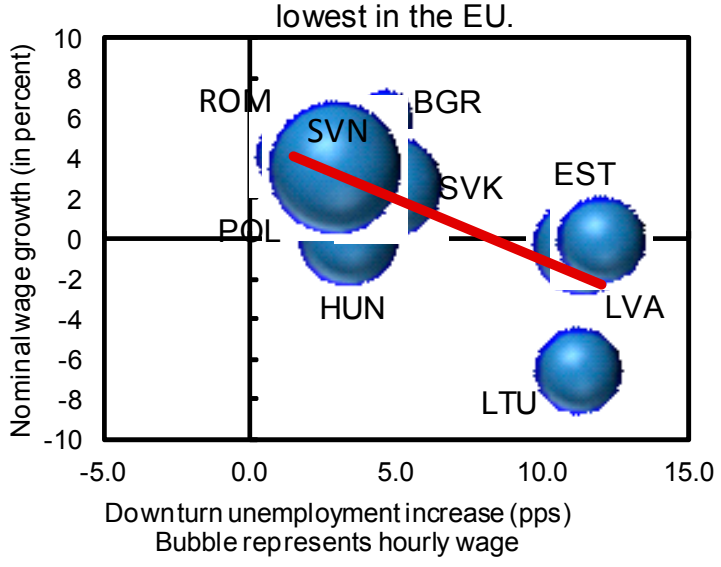

However, recent productivity increases reflect reduced employment rather than structural reforms.

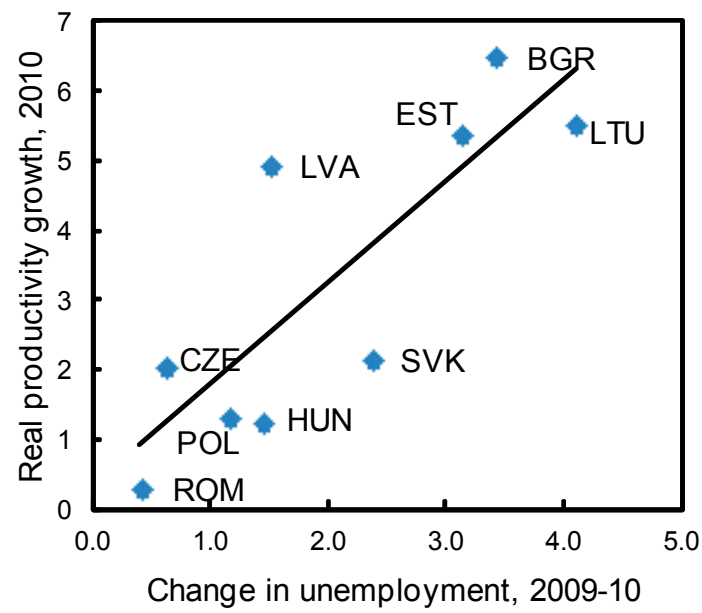

Source: Eurostat.

$1 /$ The downturn is defined as $2008-10$ and the boom the four years preceeding the downturn. 
Figure 5. Bulgaria: Fiscal Developments

Buoyant revenues prior to the crisis...
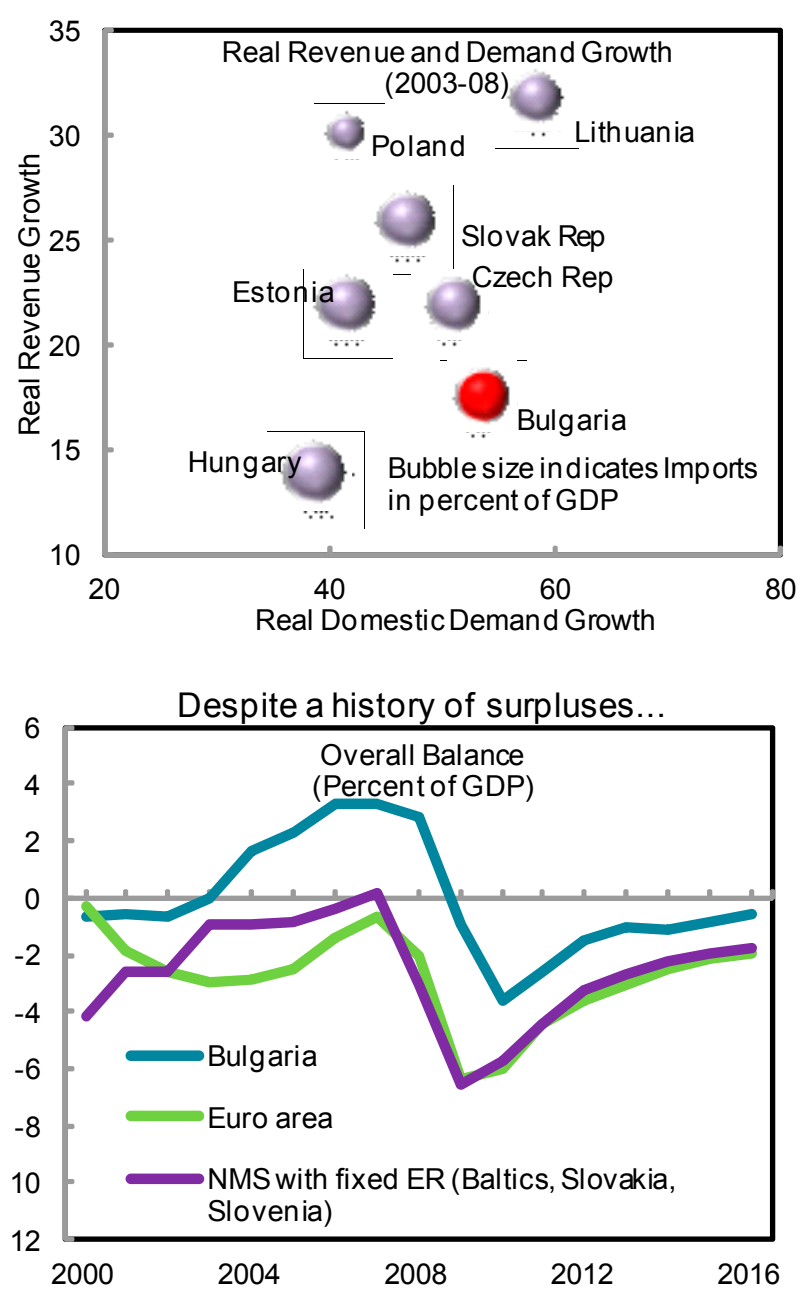

Reforms are needed to prevent unsustainable deficits from pension and health outlays.

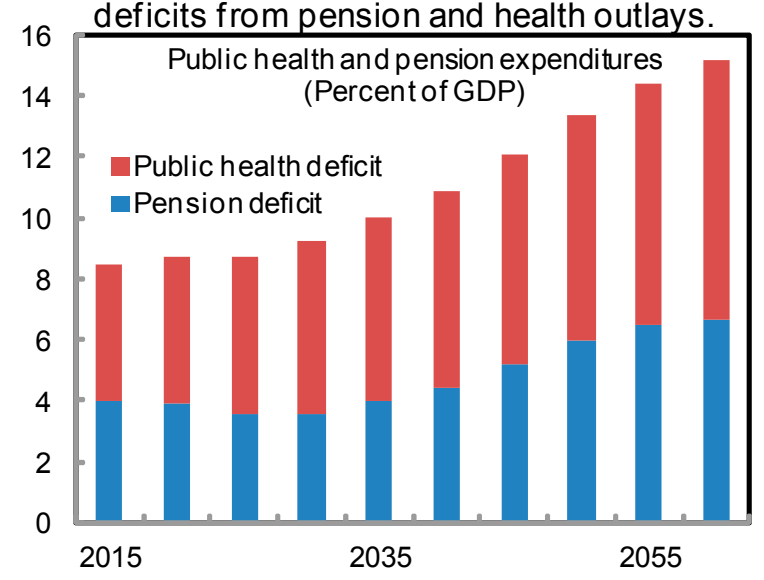

Source: WEO; Eurostat; IMF staff estimates. ...induced spending, in particular on wages and benefits.

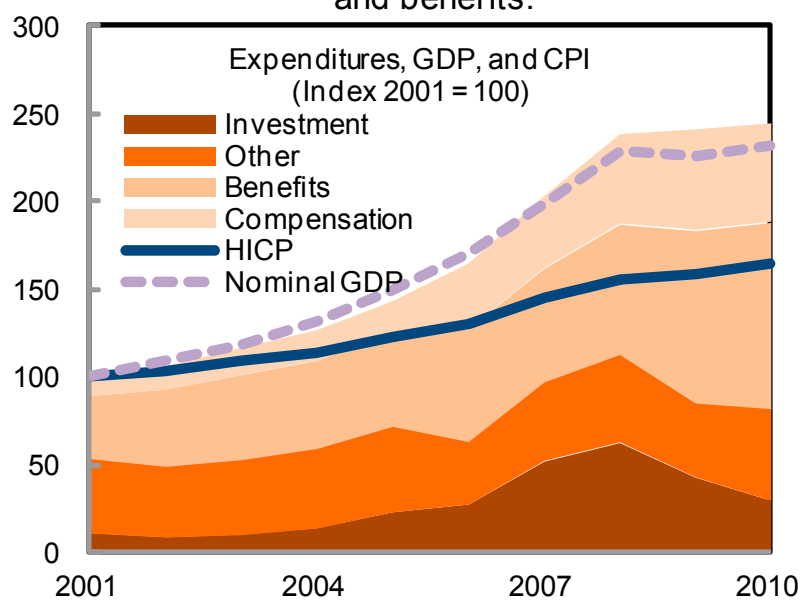

...the fiscal deficit has now to adjust to the mediumterm objective after the deterioration in 2009.

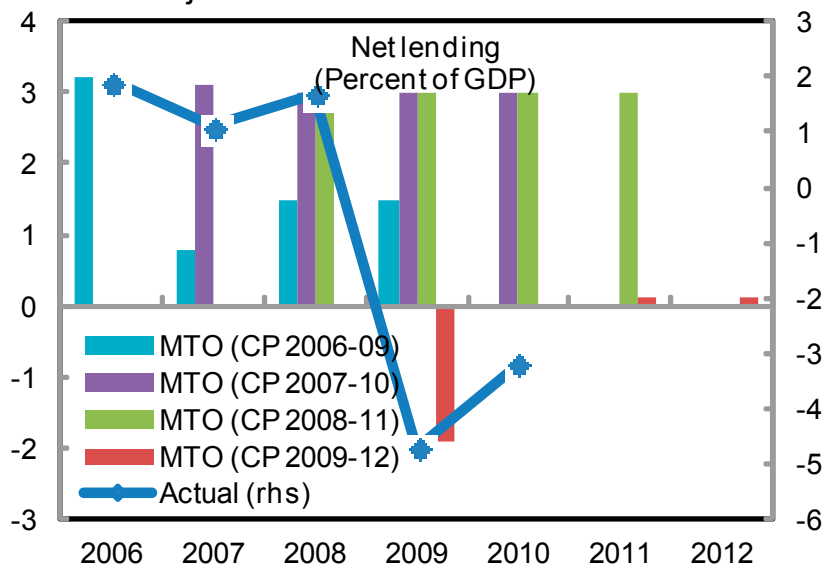

The FRA needs to be rebuilt to provide a buffer against potential shocks.

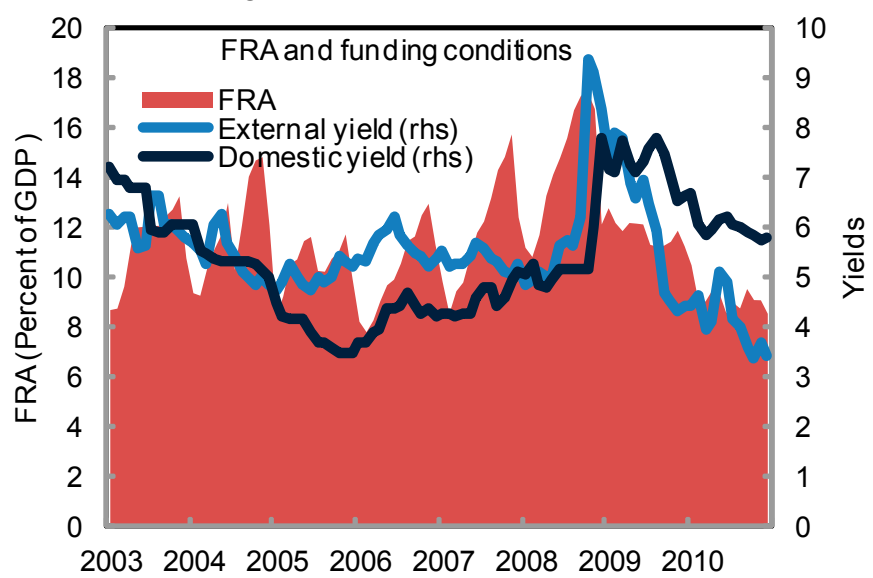


Figure 6. Bulgaria: Overview of Financial Stability Indicators in Emerging

Europe, 2008-10
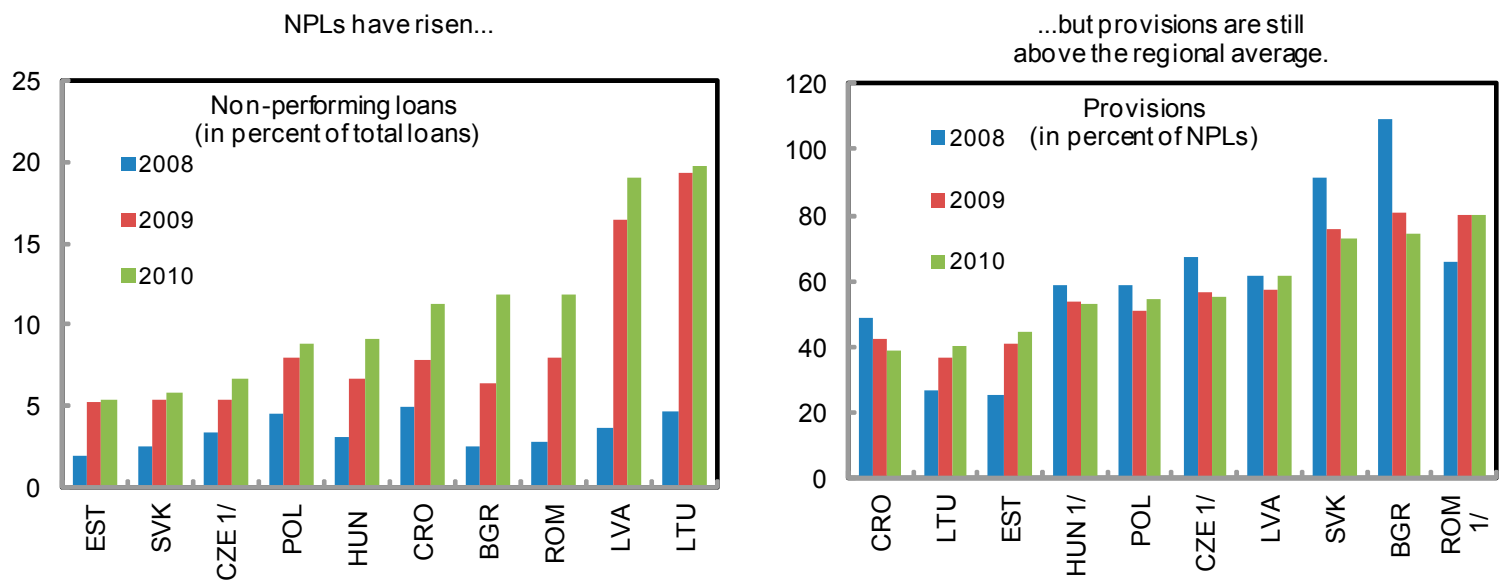

Profitability has declined markedly...
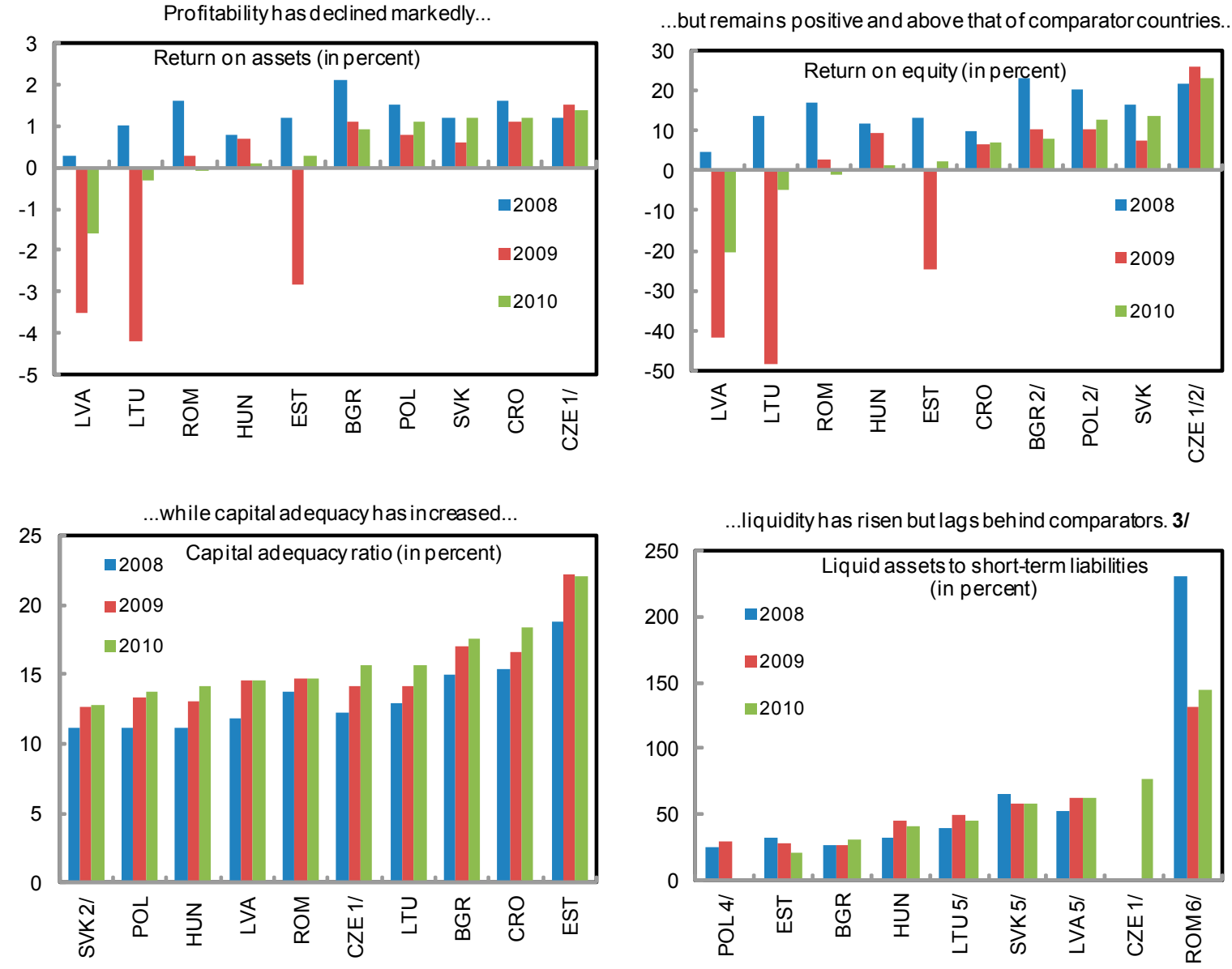

Source: GFSR April 2011; National authorities; IMF staff estimates.

1/ Latest observation: September 2010

2/ Tier 1 capital

3 / Liquid assets to short-term liabilities ratios may not be fully comparable across countries.

4/ Latest observation: September 2009

5/ Latest observation: March 2010

6/ 3-month ratio 
Table 1. Bulgaria: Selected Economic and Social Indicators, 2008-12

\begin{tabular}{|c|c|c|c|c|c|}
\hline & 2008 & 2009 & $\begin{array}{r}2010 \\
\text { Est. }\end{array}$ & $\begin{array}{r}2011 \\
\text { Proj. }\end{array}$ & $\begin{array}{r}2012 \\
\text { Proj }\end{array}$ \\
\hline Output, prices, and labor market & \multicolumn{5}{|c|}{ (Annual percentage change) } \\
\hline Real GDP & 6.2 & -5.5 & 0.2 & 3.0 & 3.5 \\
\hline Real domestic demand & 6.4 & -12.7 & -4.5 & 1.1 & 3.3 \\
\hline Consumer price index (HICP, average) & 12.0 & 2.5 & 3.0 & 4.2 & 3.1 \\
\hline Consumer price index ( $\mathrm{H} \mid \mathrm{CP}$, end of period) & 7.2 & 1.6 & 4.4 & 3.4 & 2.8 \\
\hline Unemployment rate $1 /$ & 5.7 & 6.9 & 10.3 & 9.7 & 9.0 \\
\hline Nominal wages $2 /$ & 16.5 & 8.6 & 6.0 & 6.0 & 5.8 \\
\hline General government finances & \multicolumn{5}{|c|}{ (In percent of GDP) } \\
\hline Revenue & 38.0 & 35.3 & 32.7 & 32.7 & 33.5 \\
\hline Expenditure & 35.2 & 36.2 & 36.7 & 35.2 & 35.4 \\
\hline Net lending/borrowing 3 / & 2.9 & -0.9 & -3.9 & -2.5 & -1.8 \\
\hline Privatization proceeds & 0.8 & 0.1 & 0.1 & 0.6 & 0.2 \\
\hline External financing & -1.0 & 0.9 & 0.2 & 0.6 & 3.0 \\
\hline Domestic financing & -2.7 & -0.1 & 3.7 & 2.6 & 0.8 \\
\hline Net lending and other items & $\ldots$ & $\ldots$ & -1.1 & -0.9 & 0.1 \\
\hline Gross debt (excluding guarantees) 4/ & 13.7 & 14.6 & 16.2 & 16.6 & 19.3 \\
\hline Money and credit & \multicolumn{5}{|c|}{ (Annual percentage change) } \\
\hline Broad money (M3) & 8.8 & 4.2 & 6.4 & 9.5 & 8.8 \\
\hline Domestic credit & 33.0 & 6.8 & 5.1 & 7.2 & 7.3 \\
\hline $\mathrm{o} / \mathrm{w}$ Domestic private credit & 31.6 & 3.8 & 1.3 & 5.0 & 5.5 \\
\hline Interest rates & \multicolumn{5}{|c|}{ (In percent) } \\
\hline Euro, 6-month LIBOR & 4.6 & 1.2 & 0.8 & 1.7 & 2.6 \\
\hline Interbank rate, 3-month SOFIBOR & 7.1 & 5.7 & 4.1 & $\ldots$ & $\ldots$ \\
\hline Lending rate & 10.9 & 11.3 & 11.1 & $\ldots$ & ... \\
\hline Real lending rate (HICP adjusted) & -1.0 & 8.6 & 7.9 & $\ldots$ & .. \\
\hline Balance of payments & \multicolumn{5}{|c|}{ (In percent of GDP) } \\
\hline Current account balance & -23.0 & -8.9 & -1.0 & -0.6 & -1.0 \\
\hline Merchandise trade balance & -24.3 & -11.9 & -6.7 & -5.8 & -5.8 \\
\hline Capital and financial account balance & 33.2 & 4.8 & 0.7 & 2.2 & 5.1 \\
\hline Foreign direct investment balance & 17.5 & 7.2 & 4.0 & 4.0 & 4.0 \\
\hline International investment position & -97.5 & -101.9 & -97.6 & -91.8 & -86.2 \\
\hline Gross official reserves & 35.9 & 37.0 & 36.0 & 35.3 & 37.2 \\
\hline Gross external debt & 104.9 & 108.0 & 101.8 & 94.2 & 90.6 \\
\hline \multicolumn{6}{|l|}{ Exchange rates } \\
\hline Leva per euro & \multicolumn{5}{|c|}{ Currency board peg to euro at lev 1.95583 per euro } \\
\hline Leva per U.S. dollar (end of period) & 1.39 & 1.36 & 1.47 & $\ldots$ & $\ldots$ \\
\hline \multicolumn{6}{|l|}{ Real effective exchange rate } \\
\hline CPI based (percentage change) & 8.5 & 2.1 & 1.4 & 2.8 & 1.5 \\
\hline GDP deflator based (percentage change) & 6.4 & 3.2 & 1.6 & 2.7 & 1.8 \\
\hline \multicolumn{6}{|l|}{ Social Indicators (reference year in parentheses) } \\
\hline \multicolumn{6}{|c|}{ Per capita GNI (Atlas method, 2009): US $\$ 6060$; Poverty rate (2008): 21.8 percent; } \\
\hline \multicolumn{6}{|c|}{$\begin{array}{l}\text { Life expectancy at birth (2008): } 73.3 \text { years; Mortality under } 5 \text { (per 1,000) (2009): 10; Fertility rate per woman (2008): } 1.478 \\
\text { Income distribution (Gini index, 2008): 33.5; Primary education completion rate (2008): } 89.9\end{array}$} \\
\hline
\end{tabular}

Sources: Bulgarian authorities; IMF staff estimates; World Development Indicators database; and CIA World Factbook.

1/ As percent of labor force.

2/ National accounts definition.

3/ On cash basis

4/ General government consolidated gross debt as reported under the ESA95 definition. 
Table 2: Bulgaria: Macroeconomic Framework, 2008-16

\begin{tabular}{|c|c|c|c|c|c|c|c|c|c|}
\hline & 2008 & 2009 & $\begin{array}{c}2010 \\
\text { Est. }\end{array}$ & $\begin{array}{l}2011 \\
\text { Proj. }\end{array}$ & $\begin{array}{l}2012 \\
\text { Proj. }\end{array}$ & $\begin{array}{l}2013 \\
\text { Proj. }\end{array}$ & $\begin{array}{l}2014 \\
\text { Proj. }\end{array}$ & $\begin{array}{l}2015 \\
\text { Proj. }\end{array}$ & $\begin{array}{l}2016 \\
\text { Proj. }\end{array}$ \\
\hline \multicolumn{10}{|l|}{ GDP and prices (annual percent change) } \\
\hline Ręl GDP & 6.2 & -5.5 & 0.2 & 3.0 & 3.5 & 3.7 & 3.8 & 3.9 & 4.0 \\
\hline Real domestic demand & 6.4 & -12.7 & -4.5 & 1.1 & 3.3 & 3.6 & 3.7 & 3.9 & 4.0 \\
\hline GDP deflator & 8.4 & 4.3 & 3.0 & 4.0 & 3.4 & 2.3 & 2.4 & 2.5 & 2.5 \\
\hline Domestic demand deflator & 8.9 & 2.0 & 1.2 & 5.0 & 4.1 & 3.0 & 3.0 & 2.7 & 2.5 \\
\hline Consumer price index (HICP, average) & 12.0 & 2.5 & 3.0 & 4.2 & 3.1 & 2.9 & 3.0 & 3.0 & 3.0 \\
\hline Consumer price index (HICP, end of period) & 7.2 & 1.6 & 4.4 & 3.4 & 2.8 & 3.0 & 3.0 & 3.0 & 3.0 \\
\hline Nominal wages $1 /$ & 16.5 & 8.6 & 6.0 & 6.0 & 5.9 & 5.8 & 5.8 & 5.8 & 5.8 \\
\hline Real effective exchange rate, CPI based & 8.5 & 2.1 & 1.4 & 2.8 & 1.5 & 1.3 & 1.3 & 1.3 & 1.3 \\
\hline Real effective exchange rate, GDP deflator hased & 6.4 & 3.2 & 1.6 & 2.7 & 1.9 & 0.7 & 0.7 & 0.7 & 0.7 \\
\hline \multicolumn{10}{|l|}{ Monetary aggregates (e.o.p. percent change) } \\
\hline Broad money & 8.8 & 4.2 & 6.4 & 9.5 & 8.9 & 9.3 & 9.3 & 9.5 & 9.6 \\
\hline Domestic private credit & 31.6 & 3.8 & 1.3 & 5.0 & 5.5 & 7.9 & 9.3 & 10.5 & 11.0 \\
\hline \multicolumn{10}{|l|}{ Saving and investment (in percent of GDP) } \\
\hline Foreign saving & 23.0 & 8.9 & 1.0 & 0.6 & 1.0 & 1.6 & 2.4 & 3.1 & 4.0 \\
\hline Gross national saving & 14.5 & 20.4 & 23.9 & 26.5 & 28.5 & 29.2 & 29.7 & 29.9 & 29.9 \\
\hline Government & 8.9 & 4.2 & 0.2 & 2.1 & 3.2 & 4.0 & 4.4 & 4.6 & 4.8 \\
\hline Private & 5.6 & 16.3 & 23.7 & 24.4 & 25.2 & 25.2 & 25.3 & 25.3 & 25.1 \\
\hline Gross domestic investment & 37.5 & 29.4 & 24.9 & 27.0 & 29.5 & 30.8 & 32.1 & 33.0 & 33.8 \\
\hline Government & 6.1 & 5.1 & 4.2 & 4.5 & 5.2 & 5.3 & 5.4 & 5.5 & 5.4 \\
\hline Private & 31.5 & 24.3 & 20.7 & 22.5 & 24.3 & 25.5 & 26.7 & 27.5 & 28.5 \\
\hline \multicolumn{10}{|l|}{ General government (in percent of GDP) } \\
\hline Revenue & 38.0 & 35.3 & 32.7 & 32.7 & 33.5 & 34.1 & 33.6 & 33.4 & 33.2 \\
\hline Tax revenue (including sacial security contributions) & 30.6 & 28.1 & 25.7 & 26.0 & 25.7 & 25.6 & 25.4 & 25.2 & 25.0 \\
\hline Non-Tax revenue & 5.8 & 5.2 & 4.7 & 4.2 & 3.7 & 3.6 & 3.5 & 3.5 & 3.5 \\
\hline Grants & 1.6 & 1.9 & 2.3 & 2.5 & 4.0 & 4.9 & 4.7 & 4.8 & 4.8 \\
\hline Expenditure & 35.2 & 36.2 & 36.7 & 35.2 & 35.4 & 35.4 & 34.5 & 34.3 & 33.8 \\
\hline Net lending/borrowing $2 /$ & 2.9 & -0.9 & -3.9 & -2.5 & -1.9 & -1.3 & -1.0 & -0.9 & -0.6 \\
\hline Gross debt (including guarantees) & 15.5 & 15.6 & 17.4 & 17.5 & 20.6 & 21.0 & 20.6 & 20.8 & 21.3 \\
\hline \multicolumn{10}{|l|}{ Balance of payments (in percent of GDP) } \\
\hline Current account & -23.0 & -8.9 & -1.0 & -0.6 & -1.0 & -1.6 & -2.4 & -3.1 & -4.0 \\
\hline Trade balance & -24.3 & -11.9 & -6.7 & -5.8 & -5.9 & -6.4 & -6.6 & -6.8 & -6.3 \\
\hline Services balance & 3.8 & 3.7 & 5.3 & 5.3 & 4.8 & 4.8 & 4.6 & 4.4 & 3.9 \\
\hline Income balance & -5.0 & -3.4 & -3.9 & -3.9 & -3.7 & -3.6 & -3.7 & -3.8 & -4.2 \\
\hline Transfers balance & 2.4 & 2.7 & 4.3 & 3.8 & 3.7 & 3.5 & 3.3 & 3.1 & 2.7 \\
\hline Capital and financial account & 33.2 & 4.8 & 0.7 & 2.2 & 5.1 & 2.5 & 3.8 & 3.6 & 4.8 \\
\hline Foreign direct investment & 17.5 & 7.2 & 4.0 & 4.0 & 4.0 & 4.3 & 4.4 & 5.0 & 5.0 \\
\hline \multicolumn{10}{|l|}{ Memorandum items: } \\
\hline Gross international reserves (in millions of euros) & 12,713 & 12,919 & 12,977 & 13,598 & 15,262 & 15,629 & 16,305 & 16,545 & 16,967 \\
\hline Short term debt (in percent of gross international reserves ) $3 / 4 /$ & 140 & 127 & 109 & 104 & 96 & 92 & 99 & 100 & 91 \\
\hline International investment position (in percent of GDP) & -98 & -102 & -98 & -92 & -86 & -81 & -77 & -73 & -71 \\
\hline External debt (in percent of GDP) & 105 & 108 & 102 & 94 & 91 & 84 & 78 & 72 & 67 \\
\hline Short-term external debt (in percent of GDP) $5 /$ & 37.2 & 35.4 & 31.9 & 28.9 & 26.8 & 26.0 & 24.9 & 23.9 & 23.1 \\
\hline Export volume (percent change) & 11.5 & -14.4 & 7.6 & 9.3 & 6.9 & 6.1 & 6.2 & 6.0 & 6.2 \\
\hline Import volume (percent change) & 3.4 & -26.5 & -6.0 & 6.7 & 6.6 & 6.4 & 5.7 & 5.5 & 5.1 \\
\hline Terms of trade (percent change) & -2.3 & -1.0 & 2.6 & 0.4 & -0.4 & -0.9 & -1.1 & -0.9 & -0.1 \\
\hline Nominal GDP (in millions of leva) & 69,295 & 68,322 & 70,474 & 75,492 & 80,762 & 85,677 & 91,067 & 96,984 & 103,385 \\
\hline Nominal GDP (in millions of euros) & 35,430 & 34,932 & 36,033 & 38,598 & 41,293 & 43,806 & 46,562 & 49,587 & 52,860 \\
\hline
\end{tabular}

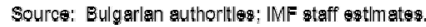

1/ Nat|onal accounts definition.

2/ On casक bas:s

3 / Including deposits of forelgn banks In local subs|d|larles.

4/ At remaining maturity

$5 /$ At orlginal maturity. 
Table 3. Bulgaria: Real GDP Components, 2008-16

\begin{tabular}{|c|c|c|c|c|c|c|c|c|c|}
\hline & 2008 & 2009 & $\begin{array}{r}2010 \\
\text { Est. }\end{array}$ & $\begin{array}{l}2011 \\
\text { Proj. }\end{array}$ & $\begin{array}{c}2012 \\
\text { Proj. }\end{array}$ & $\begin{array}{l}2013 \\
\text { Proj. }\end{array}$ & $\begin{array}{c}2014 \\
\text { Proj. }\end{array}$ & $\begin{array}{l}2015 \\
\text { Proj. }\end{array}$ & $\begin{array}{l}2016 \\
\text { Proj }\end{array}$ \\
\hline \multicolumn{10}{|c|}{ (Real growth rate by expenditure category, in percent) } \\
\hline Real GDP & 6.2 & -5.5 & 0.2 & 3.0 & 3.5 & 3.7 & 3.8 & 3.9 & 4.0 \\
\hline Domestic demand & 6.4 & -12.7 & -4.5 & 1.1 & 3.3 & 3.6 & 3.7 & 3.9 & 4.0 \\
\hline Private demand & 7.5 & -13.2 & -4.4 & 0.5 & 2.4 & 3.7 & 4.0 & 4.1 & 4.5 \\
\hline Public demand & 1.2 & -10.2 & -5.0 & 3.9 & 7.8 & 2.8 & 2.0 & 3.2 & 1.9 \\
\hline Final consumption & 2.6 & -7.4 & -1.2 & 0.6 & 1.5 & 2.1 & 2.6 & 2.8 & 2.7 \\
\hline Private consumption & 3.4 & -7.6 & -1.2 & 0.7 & 1.2 & 2.4 & 3.2 & 3.2 & 3.1 \\
\hline Public consumption & -1.0 & -6.5 & -1.0 & 0.3 & 3.2 & 0.7 & -0.6 & 0.8 & 0.8 \\
\hline Investment & 16.3 & -24.9 & -14.0 & 2.7 & 9.0 & 7.8 & 6.7 & 7.0 & 7.4 \\
\hline Gross fixed investment & 21.9 & -17.6 & -16.5 & 3.9 & 8.5 & 7.7 & 7.6 & 7.6 & 7.5 \\
\hline Private investment & 25.7 & -17.2 & -16.6 & 1.3 & 5.4 & 7.6 & 7.5 & 7.5 & 8.5 \\
\hline Public investment & 6.8 & -19.2 & -15.9 & 15.7 & 20.9 & 8.0 & 8.1 & 8.2 & 4.1 \\
\hline Inventories $1 /$ & -0.8 & -3.6 & 0.6 & -0.2 & 0.2 & 0.2 & -0.1 & -0.1 & 0.1 \\
\hline Net exports $1 /$ & -1.9 & 11.8 & 6.2 & 0.8 & -0.1 & -0.2 & -0.2 & -0.4 & -0.4 \\
\hline Exports of goods and services & 3.0 & -11.2 & 16.2 & 9.1 & 5.4 & 4.8 & 3.0 & 4.4 & 5.2 \\
\hline Imports of goods and services & 4.2 & -21.0 & 4.5 & 7.0 & 5.0 & 4.5 & 2.9 & 4.4 & 5.1 \\
\hline \multicolumn{10}{|c|}{ (Contribution to real GDP growth, in percent) } \\
\hline Domestic demand & 8.1 & -16.0 & -5.3 & 1.2 & 3.6 & 3.9 & 4.0 & 4.3 & 4.4 \\
\hline Private demand & 7.8 & -13.9 & -4.3 & 0.5 & 2.1 & 3.3 & 3.6 & 3.7 & 4.0 \\
\hline Public demand & 0.3 & -2.1 & -1.0 & 0.7 & 1.5 & 0.5 & 0.4 & 0.6 & 0.4 \\
\hline Final consumption & 2.4 & -6.5 & -1.0 & 0.5 & 1.2 & 1.7 & 2.0 & 2.2 & 2.1 \\
\hline Private consumption & 2.6 & -5.5 & -0.8 & 0.5 & 0.8 & 1.6 & 2.1 & 2.1 & 2.0 \\
\hline Public consumption & -0.2 & -0.9 & -0.1 & 0.0 & 0.4 & 0.1 & -0.1 & 0.1 & 0.1 \\
\hline Investment & 5.7 & -9.5 & -4.3 & 0.7 & 2.3 & 2.1 & 1.9 & 2.0 & 2.2 \\
\hline Gross fixed investment & 6.4 & -5.9 & -4.9 & 1.0 & 2.1 & 2.0 & 2.1 & 2.1 & 2.2 \\
\hline Private investment & 6.0 & -4.8 & -4.0 & 0.3 & 1.1 & 1.5 & 1.6 & 1.6 & 1.9 \\
\hline Public investment & 0.4 & -1.2 & -0.8 & 0.7 & 1.0 & 0.5 & 0.5 & 0.5 & 0.3 \\
\hline Inventories & -0.8 & -3.6 & 0.6 & -0.2 & 0.2 & 0.2 & -0.1 & -0.1 & 0.1 \\
\hline Net exports & -1.9 & 11.8 & 6.2 & 0.8 & -0.1 & -0.2 & -0.2 & -0.4 & -0.4 \\
\hline Exports of goods and services & 2.0 & -7.0 & 9.6 & 6.3 & 3.9 & 3.5 & 2.3 & 3.3 & 3.9 \\
\hline Imports of goods and services & 3.9 & -18.8 & 3.4 & 5.5 & 4.0 & 3.7 & 2.4 & 3.7 & 4.2 \\
\hline
\end{tabular}

Source: Bulgaria National Statistical Institute (NSI); IMF staff estimates.

1/ Contributions to GDP growth. 
Table 4. Bulgaria: Balance of Payments, 2008-16 (In millions of Euros, unless otherwise indicated)

\begin{tabular}{|c|c|c|c|c|c|c|c|c|c|}
\hline & 2008 & 2009 & $\begin{array}{l}2010 \\
\text { Prel. }\end{array}$ & $\begin{array}{l}2011 \\
\text { Proj. }\end{array}$ & $\begin{array}{l}2012 \\
\text { Proj. }\end{array}$ & $\begin{array}{l}2013 \\
\text { Proj. }\end{array}$ & $\begin{array}{c}2014 \\
\text { Proj. }\end{array}$ & $\begin{array}{c}2015 \\
\text { Proj. }\end{array}$ & $\begin{array}{l}2016 \\
\text { Proj. }\end{array}$ \\
\hline Current account balance & $-8,163$ & $-3,117$ & -356 & -217 & -410 & -708 & $-1,099$ & $-1,537$ & $-2,097$ \\
\hline Trade balance & $-8,598$ & $-4,173$ & $-2,413$ & $-2,239$ & $-2,415$ & $-2,812$ & $-3,072$ & $-3,352$ & $-3,344$ \\
\hline Exports (f.o.b.) & 15,204 & 11,700 & 15,588 & 18,243 & 19,369 & 20,400 & 21,197 & 22,364 & 24,023 \\
\hline Imports (f.o.b.) & $-23,801$ & $-15,873$ & $-18,001$ & $-20,482$ & $-21,784$ & $-23,212$ & $-24,269$ & $-25,717$ & $-27,367$ \\
\hline Services balance & 1,329 & 1,300 & 1,902 & 2,041 & 1,992 & 2,120 & 2,124 & 2,174 & 2,048 \\
\hline Exports of non-factor services & 5,375 & 4,917 & 5,283 & 5,674 & 6,150 & 6,685 & 7,068 & 7,606 & 7,848 \\
\hline Income balance & $-1,756$ & $-1,200$ & $-1,392$ & $-1,487$ & $-1,528$ & $-1,556$ & $-1,700$ & $-1,887$ & $-2,241$ \\
\hline Receipts & 985 & 803 & 635 & 655 & 798 & 916 & 933 & 914 & 902 \\
\hline Payments & $-2,741$ & $-2,003$ & $-2,028$ & $-2,142$ & $-2,326$ & $-2,472$ & $-2,632$ & $-2,802$ & $-3,143$ \\
\hline Current transfer balance & 861 & 956 & 1,547 & 1,468 & 1,540 & 1,540 & 1,549 & 1,528 & 1,439 \\
\hline Capital and financial account balance & 11,751 & 1,669 & 261 & 838 & 2,074 & 1,075 & 1,775 & 1,776 & 2,520 \\
\hline Capital transfer balance & 277 & 477 & 291 & 395 & 320 & 295 & 298 & 298 & 340 \\
\hline Foreign direct investment balance & 6,212 & 2,498 & 1,459 & 1,533 & 1,656 & 1,897 & 2,026 & 2,474 & 2,635 \\
\hline Portfolio investment balance & -774 & -589 & -686 & -778 & -776 & -797 & -749 & -735 & -745 \\
\hline General govemment and monetary authorities & -308 & 304 & 70 & 236 & 1,247 & -398 & 101 & -446 & 18 \\
\hline Domestic banks & 3,564 & -848 & $-1,216$ & -629 & -465 & -12 & 16 & 92 & 126 \\
\hline Other private sector & 2,779 & -175 & 378 & 81 & 92 & 90 & 83 & 94 & 146 \\
\hline Errors and omissions & $-2,914$ & 801 & -318 & 0 & 0 & 0 & 0 & 0 & 0 \\
\hline Overall balance & 674 & -650 & -384 & 621 & 1,664 & 367 & 676 & 239 & 423 \\
\hline Financing & -674 & 650 & 384 & -621 & $-1,664$ & -367 & -676 & -239 & -423 \\
\hline Gross international reserves (increase: -) & -674 & 650 & 384 & -621 & $-1,664$ & -367 & -676 & -239 & -423 \\
\hline Use of Fund credit, net & 0 & 0 & 0 & 0 & 0 & 0 & 0 & 0 & 0 \\
\hline Purchases & 0 & 0 & 0 & 0 & 0 & 0 & 0 & 0 & 0 \\
\hline Repurchases & 0 & 0 & 0 & 0 & 0 & 0 & 0 & 0 & 0 \\
\hline \multicolumn{10}{|l|}{ Memorandum items: } \\
\hline & \multicolumn{9}{|c|}{ (in percent of GDP, unless otherwise indicated) } \\
\hline Current account balance & -23.0 & -8.9 & -1.0 & -0.6 & -1.0 & -1.6 & -2.4 & -3.1 & -4.0 \\
\hline Foreign direct investment balance & 17.5 & 7.2 & 4.0 & 4.0 & 4.0 & 4.3 & 4.4 & 5.0 & 5.0 \\
\hline Gross extemal financing requirement & 49.2 & 44.4 & 33.3 & 25.5 & 24.5 & 24.8 & 23.5 & 26.3 & 23.3 \\
\hline Gross BNB reserves (in millions of Euro) & 12,713 & 12,919 & 12,977 & 13,598 & 15,262 & 15,629 & 16,305 & 16,545 & 16,967 \\
\hline S.t. debt at originating maturity, in percent of reserves & 104 & 96 & 89 & 82 & 73 & 73 & 71 & 72 & 72 \\
\hline S.t. debt at remaining maturity, in percent of reserves & 140 & 127 & 109 & 104 & 96 & 92 & 99 & 100 & 91 \\
\hline Terms of trade (merchandise) & -2.3 & -1.0 & 2.6 & 0.4 & -0.4 & -0.9 & -1.1 & -0.9 & -0.1 \\
\hline Exports of goods (volume, growth rate) & 11.5 & -14.4 & 7.6 & 9.3 & 6.9 & 6.1 & 6.2 & 6.0 & 6.2 \\
\hline Imports of goods (volume, growth rate) & 3.4 & -26.5 & -6.0 & 6.7 & 6.6 & 6.4 & 5.7 & 5.5 & 5.1 \\
\hline Exports of goods (prices, growth rate) & 0.9 & -10.1 & 23.8 & 7.1 & -0.7 & -0.7 & -2.2 & -0.4 & 1.1 \\
\hline Imports of goods (prices, growth rate) & 3.3 & -9.2 & 20.7 & 6.6 & -0.3 & 0.2 & -1.1 & 0.4 & 1.3 \\
\hline Exports of goods and services (prices, growth rate) & 9.4 & -9.0 & 8.1 & 5.0 & 1.2 & 1.3 & 1.3 & 1.6 & 1.1 \\
\hline Imports of goods and services (prices, growth rate) & 9.6 & -11.4 & 5.0 & 5.3 & 2.5 & 2.5 & 2.2 & 2.0 & 1.3 \\
\hline Exports of goods and services (volumes, growth rate) & 2.9 & -11.3 & 16.2 & 9.1 & 5.4 & 4.8 & 3.0 & 4.4 & 5.2 \\
\hline Imports of goods and services (volumes, growth rate) & -1.8 & -21.0 & 4.5 & 7.1 & 5.0 & 4.5 & 2.9 & 4.5 & 5.1 \\
\hline GDP & 35,430 & 34,932 & 36,033 & 38,598 & 41,293 & 43,806 & 46,562 & 49,587 & 52,860 \\
\hline
\end{tabular}

Sources: Bulgarlan authorltles; IMF staff estlmates. 
Table 5a. Bulgaria: General Government Operations, 2008-16 1/ (In millions of leva)

\begin{tabular}{|c|c|c|c|c|c|c|c|c|c|}
\hline & 2008 & 2009 & 2010 & $\begin{array}{l}2011 \\
\text { Proj. }\end{array}$ & $\begin{array}{c}2012 \\
\text { Proj. }\end{array}$ & $\begin{array}{l}2013 \\
\text { Proj. }\end{array}$ & $\begin{array}{c}2014 \\
\text { Proj. }\end{array}$ & $\begin{array}{l}2015 \\
\text { Proj. }\end{array}$ & $\begin{array}{c}2016 \\
\text { Proj. }\end{array}$ \\
\hline \multicolumn{10}{|l|}{ Statement of Operations } \\
\hline $\begin{array}{l}\text { Revenue } \\
\end{array}$ & 26,359 & 24,087 & 23,053 & 24,680 & 27,027 & 29,217 & 30,578 & 32,404 & 34,344 \\
\hline Taxes & 16,774 & 14,898 & 14,044 & 15,093 & 15,970 & 16,908 & 17,860 & 18,884 & 19,968 \\
\hline Taxes on profits & 2,228 & 1,762 & 1,353 & 1,521 & 1,694 & 1,872 & 1,999 & 2,137 & 2,285 \\
\hline Taxes on income & 1,971 & 2,051 & 2,031 & 2,161 & 2,287 & 2,403 & 2,525 & 2,653 & 2,788 \\
\hline Value-added taxes & 7,485 & 6,433 & 6,267 & 6,656 & 6,900 & 7,230 & 7,595 & 7,972 & 8,369 \\
\hline Excises & 4,052 & 3,844 & 3,568 & 3,850 & 4,119 & 4,382 & 4,667 & 4,975 & 5,303 \\
\hline Customs duties & 221 & 122 & 119 & 112 & 115 & 105 & 95 & 95 & 95 \\
\hline Other taxes & 816 & 686 & 705 & 794 & 855 & 916 & 980 & 1,051 & 1,127 \\
\hline Social contributions & 4,438 & 4,321 & 4,091 & 4,528 & 4,791 & 5,033 & 5,289 & 5,558 & 5,841 \\
\hline Grants & 1,142 & 1,326 & 1,603 & 1,917 & 3,270 & 4,181 & 4,281 & 4,608 & 4,959 \\
\hline Other revenue 2 / & 4,005 & 3,543 & 3,315 & 3,141 & 2,997 & 3,095 & 3,147 & 3,355 & 3,576 \\
\hline Expenditure & 24,369 & 24,714 & 25,834 & 26,538 & 28,589 & 30,303 & 31,456 & 33,233 & 34,930 \\
\hline Expense & 19,854 & 20,926 & 21,573 & 22,580 & 24,054 & 25,409 & 26,154 & 27,507 & 28,961 \\
\hline Compensation of employees & 3,836 & 4,103 & 4,146 & 4,146 & 4,023 & 4,184 & 4,445 & 4,691 & 4,950 \\
\hline Use of goods and services & 4,913 & 4,296 & 4,266 & 4,654 & 4,966 & 4,991 & 5,110 & 5,238 & 5,369 \\
\hline Interest & 585 & 521 & 486 & 584 & 725 & 917 & 813 & 813 & 813 \\
\hline Subsidies & 1,114 & 1,204 & 1,317 & 1,433 & 2,218 & 2,507 & 2,183 & 2,327 & 2,481 \\
\hline Grants 3/ & 720 & 746 & 670 & 726 & 896 & 957 & 1,024 & 1,024 & 1,024 \\
\hline Social benefits & 8,594 & 9,955 & 10,583 & 10,940 & 11,154 & 11,776 & 12,497 & 13,327 & 14,232 \\
\hline Pensions & 5,546 & 6,439 & 6,971 & 7,021 & 7,234 & 7,605 & 7,980 & 8,372 & 8,781 \\
\hline Social assistance & 1,536 & 1,855 & 1,797 & 1,945 & 1,946 & 1,983 & 2,000 & 2,060 & 2,122 \\
\hline Healthcare & 1,512 & 1,661 & 1,815 & 1,975 & 1,975 & 2,189 & 2,517 & 2,894 & 3,329 \\
\hline Other expense & 93 & 101 & 104 & 96 & 73 & 77 & 81 & 87 & 92 \\
\hline Contingency $4 /$ & 317 & 302 & 1,317 & 527 & 369 & 377 & 398 & 398 & 398 \\
\hline Net acquisition of nonfinancial assets $/ 5$ & 4,198 & 3,487 & 2,945 & 3,430 & 4,166 & 4,517 & 4,903 & 5,327 & 5,570 \\
\hline Net lending/borrowing $1 /$ & 1,990 & -627 & $-2,781$ & $-1,858$ & $-1,562$ & $-1,086$ & -878 & -829 & -586 \\
\hline Primary balance & 2,575 & -106 & $-2,295$ & $-1,274$ & -837 & -170 & -65 & -16 & 227 \\
\hline \multicolumn{10}{|l|}{ (financed by) } \\
\hline Net acquisition of financial assets & $\ldots$ & $\ldots$ & -830 & -38 & 2,823 & 895 & 977 & 1,066 & 2,698 \\
\hline Domestic & $\ldots$ & $\ldots$ & $-1,050$ & -306 & 2,534 & 607 & 612 & 689 & 2,333 \\
\hline Foreign & $\ldots$ & $\ldots$ & 220 & 268 & 289 & 288 & 364 & 377 & 364 \\
\hline Net incurrence of liabilities & $\ldots$ & $\ldots$ & 1,950 & 1,820 & 4,385 & 1,982 & 1,855 & 1,895 & 3,283 \\
\hline Domestic & $\ldots$ & $\ldots$ & 1,569 & 1,012 & 1,566 & 1,206 & 1,200 & 1,000 & 2,388 \\
\hline Foreign & $\ldots$ & $\ldots$ & 381 & 808 & 2,819 & 776 & 655 & 895 & 895 \\
\hline \multicolumn{10}{|l|}{ Financial Balance Sheet } \\
\hline $\begin{array}{l}\text { Financial assets } \\
\text { nats }\end{array}$ & 20,143 & 20,104 & 20,131 & 20,081 & $\ldots$ & $\ldots$ & $\ldots$ & $\ldots$ & $\ldots$ \\
\hline Currency and deposits & 8,763 & 7,313 & 5,706 & 4,582 & $\ldots$ & $\ldots$ & $\ldots$ & $\ldots$ & $\ldots$ \\
\hline Loans & 1,300 & 1,248 & 1,026 & 1,102 & $\ldots$ & $\ldots$ & $\ldots$ & $\ldots$ & $\ldots$ \\
\hline Debt securities & 0 & 0 & 0 & 0 & $\ldots$ & $\ldots$ & $\ldots$ & $\ldots$ & $\ldots$ \\
\hline Equity and investment fund shares & 6,762 & 7,784 & 8,377 & 9,001 & $\ldots$ & $\ldots$ & $\ldots$ & $\ldots$ & $\ldots$ \\
\hline Other financial assets & 3,318 & 3,759 & 5,022 & 5,396 & $\ldots$ & $\cdots$ & $\cdots$ & $\cdots$ & $\cdots$ \\
\hline Financial liabilities & 12,476 & 15,568 & 17,343 & 18,635 & $\ldots$ & $\ldots$ & $\ldots$ & $\ldots$ & $\ldots$ \\
\hline Currency and deposits & 0 & 0 & 0 & 0 & $\ldots$ & $\ldots$ & $\ldots$ & $\ldots$ & $\ldots$ \\
\hline Loans & 3,481 & 4,135 & 4,582 & 4,923 & $\ldots$ & $\ldots$ & $\ldots$ & $\ldots$ & $\ldots$ \\
\hline Equity and investment fund shares & 6,195 & 6,359 & 7,378 & 7,927 & $\ldots$ & $\ldots$ & $\ldots$ & $\ldots$ & $\ldots$ \\
\hline Other liabilities & 2,800 & 5,074 & 5,383 & 5,784 & $\ldots$ & $\ldots$ & $\ldots$ & $\ldots$ & $\ldots$ \\
\hline \multicolumn{10}{|l|}{ Memorandum items: } \\
\hline Net financial worth & 7,667 & 4,536 & 2,788 & 1,446 & $\ldots$ & $\ldots$ & $\ldots$ & $\ldots$ & $\ldots$ \\
\hline Fiscal reserve account & 8,382 & 7,673 & 6,012 & 4,827 & $\ldots$ & $\ldots$ & $\ldots$ & $\ldots$ & $\ldots$ \\
\hline Gross debt 6/ & 10,710 & 10,641 & 12,240 & 13,249 & 16,609 & 18,032 & 18,803 & 20,138 & 22,018 \\
\hline Foreign & 7,637 & 7,631 & 8,156 & 8,696 & 11,226 & 11,714 & 12,004 & 12,522 & 13,052 \\
\hline Domestic & 3,073 & 3,009 & 4,084 & 4,553 & 5,383 & 6,318 & 6,799 & 7,616 & 8,965 \\
\hline
\end{tabular}

Source: Ministry of Finance; IMF staff estimates.

1/ On cash basis.

2/ Includes sales of fixed assets.

3/ Contribution to EU budget.

4/ The contingency reserve in 2010 includes BGN $527 \mathrm{mln}$ in arrears repayment; $218 \mathrm{mln}$ for road infrastructure; $45 \mathrm{mln}$ for railway infrastructure;

$116 \mathrm{mln}$ for subsidies (mostly agriculture); $142 \mathrm{mln}$ for social security; and $81 \mathrm{mln}$ for natural disasters.

$5 /$ Includes only acquisitions of nonfinancial assets, i.e. capital expenditure.

6/ Includes guarantees. 
Table 5b. Bulgaria: General Government Operations, 2008-16 (In percent of GDP)

\begin{tabular}{|c|c|c|c|c|c|c|c|c|c|}
\hline & 2008 & 2009 & 2010 & $\begin{array}{c}2011 \\
\text { Proj. }\end{array}$ & $\begin{array}{c}2012 \\
\text { Proj. }\end{array}$ & $\begin{array}{c}2013 \\
\text { Proj. }\end{array}$ & $\begin{array}{c}2014 \\
\text { Proj. }\end{array}$ & $\begin{array}{c}2015 \\
\text { Proj. }\end{array}$ & $\begin{array}{c}2016 \\
\text { Proj. }\end{array}$ \\
\hline \multicolumn{10}{|l|}{ Statement of Operations } \\
\hline$\overline{\text { Revenue }}$ & 38.0 & 35.3 & 32.7 & 32.7 & 33.5 & 34.1 & 33.6 & 33.4 & 33.2 \\
\hline Taxes & 24.2 & 21.8 & 19.9 & 20.0 & 19.8 & 19.7 & 19.6 & 19.5 & 19.3 \\
\hline Taxes on profits & 3.2 & 2.6 & 1.9 & 2.0 & 2.1 & 2.2 & 2.2 & 2.2 & 2.2 \\
\hline Taxes on income & 2.8 & 3.0 & 2.9 & 2.9 & 2.8 & 2.8 & 2.8 & 2.7 & 2.7 \\
\hline Value-added taxes & 10.8 & 9.4 & 8.9 & 8.8 & 8.5 & 8.4 & 8.3 & 8.2 & 8.1 \\
\hline Excises & 5.8 & 5.6 & 5.1 & 5.1 & 5.1 & 5.1 & 5.1 & 5.1 & 5.1 \\
\hline Customs duties & 0.3 & 0.2 & 0.2 & 0.1 & 0.1 & 0.1 & 0.1 & 0.1 & 0.1 \\
\hline Other taxes & 1.2 & 1.0 & 1.0 & 1.1 & 1.1 & 1.1 & 1.1 & 1.1 & 1.1 \\
\hline Social contributions & 6.4 & 6.3 & 5.8 & 6.0 & 5.9 & 5.9 & 5.8 & 5.7 & 5.6 \\
\hline Grants & 1.6 & 1.9 & 2.3 & 2.5 & 4.0 & 4.9 & 4.7 & 4.8 & 4.8 \\
\hline Other revenue 2 / & 5.8 & 5.2 & 4.7 & 4.2 & 3.7 & 3.6 & 3.5 & 3.5 & 3.5 \\
\hline Expenditure & 35.2 & 36.2 & 36.7 & 35.2 & 35.4 & 35.4 & 34.5 & 34.3 & 33.8 \\
\hline Expense & 28.7 & 30.6 & 30.6 & 29.9 & 29.8 & 29.7 & 28.7 & 28.4 & 28.0 \\
\hline Compensation of employees & 5.5 & 6.0 & 5.9 & 5.5 & 5.0 & 4.9 & 4.9 & 4.8 & 4.8 \\
\hline Use of goods and services & 7.1 & 6.3 & 6.1 & 6.2 & 6.1 & 5.8 & 5.6 & 5.4 & 5.2 \\
\hline Interest & 0.8 & 0.8 & 0.7 & 0.8 & 0.9 & 1.1 & 0.9 & 0.8 & 0.8 \\
\hline Subsidies & 1.6 & 1.8 & 1.9 & 1.9 & 2.7 & 2.9 & 2.4 & 2.4 & 2.4 \\
\hline Grants 3/ & 1.0 & 1.1 & 1.0 & 1.0 & 1.1 & 1.1 & 1.1 & 1.1 & 1.0 \\
\hline Social benefits & 12.4 & 14.6 & 15.0 & 14.5 & 13.8 & 13.7 & 13.7 & 13.7 & 13.8 \\
\hline Pensions & 8.0 & 9.4 & 9.9 & 9.3 & 9.0 & 8.9 & 8.8 & 8.6 & 8.5 \\
\hline Social assistance & 2.2 & 2.7 & 2.6 & 2.6 & 2.4 & 2.3 & 2.2 & 2.1 & 2.1 \\
\hline Healthcare & 2.2 & 2.4 & 2.6 & 2.6 & 2.4 & 2.6 & 2.8 & 3.0 & 3.2 \\
\hline Other expense & 0.1 & 0.1 & 0.1 & 0.1 & 0.1 & 0.1 & 0.1 & 0.1 & 0.1 \\
\hline Contingency $4 /$ & 0.5 & 0.4 & 1.9 & 0.7 & 0.5 & 0.4 & 0.4 & 0.4 & 0.4 \\
\hline Net acquisition of nonfinancial assets $/ 5$ & 6.1 & 5.1 & 4.2 & 4.5 & 5.2 & 5.3 & 5.4 & 5.5 & 5.4 \\
\hline Net lending/borrowing $1 /$ & 2.9 & -0.9 & -3.9 & -2.5 & -1.9 & -1.3 & -1.0 & -0.9 & -0.6 \\
\hline Primary balance & 3.7 & -0.2 & -3.3 & -1.7 & -1.0 & -0.2 & -0.1 & 0.0 & 0.2 \\
\hline \multicolumn{10}{|l|}{ (financed by) } \\
\hline Net acquisition of financial assets & $\ldots$ & $\ldots$ & -1.2 & 0.0 & 3.5 & 1.0 & 1.1 & 1.1 & 2.6 \\
\hline Domestic & $\ldots$ & $\ldots$ & -1.5 & -0.4 & 3.1 & 0.7 & 0.7 & 0.7 & 2.3 \\
\hline Foreign & $\ldots$ & $\ldots$ & 0.3 & 0.4 & 0.4 & 0.3 & 0.4 & 0.4 & 0.4 \\
\hline Net incurrence of liabilities & $\ldots$ & $\ldots$ & 2.8 & 2.4 & 5.4 & 2.3 & 2.0 & 2.0 & 3.2 \\
\hline Domestic & $\ldots$ & $\ldots$ & 2.2 & 1.3 & 1.9 & 1.4 & 1.3 & 1.0 & 2.3 \\
\hline Foreign & $\ldots$ & $\ldots$ & 0.5 & 1.1 & 3.5 & 0.9 & 0.7 & 0.9 & 0.9 \\
\hline \multicolumn{10}{|l|}{ Financial Balance Sheet } \\
\hline$\overline{\text { Financial assets }}$ & 29.1 & 29.4 & 28.6 & 26.6 & $\ldots$ & $\ldots$ & $\ldots$ & $\ldots$ & $\ldots$ \\
\hline Currency and deposits & 12.6 & 10.7 & 8.1 & 6.1 & $\ldots$ & $\ldots$ & $\ldots$ & $\ldots$ & $\ldots$ \\
\hline Loans & 1.9 & 1.8 & 1.5 & 1.5 & $\ldots$ & $\ldots$ & $\ldots$ & $\ldots$ & $\ldots$ \\
\hline Debt securities & 0.0 & 0.0 & 0.0 & 0.0 & $\ldots$ & $\ldots$ & $\ldots$ & $\ldots$ & $\ldots$ \\
\hline Equity and investment fund shares & 9.8 & 11.4 & 11.9 & 11.9 & $\ldots$ & $\ldots$ & $\ldots$ & $\ldots$ & $\ldots$ \\
\hline Other financial assets & 4.8 & 5.5 & 7.1 & 7.1 & $\ldots$ & $\ldots$ & $\ldots$ & $\ldots$ & $\ldots$ \\
\hline Financial liabilities & 18.0 & 22.8 & 24.6 & 24.7 & $\ldots$ & $\ldots$ & $\ldots$ & $\ldots$ & $\ldots$ \\
\hline Currency and deposits & 0.0 & 0.0 & 0.0 & 0.0 & $\ldots$ & $\ldots$ & $\ldots$ & $\ldots$ & $\ldots$ \\
\hline Loans & 5.0 & 6.1 & 6.5 & 6.5 & $\ldots$ & $\ldots$ & $\ldots$ & $\ldots$ & $\ldots$ \\
\hline Equity and investment fund shares & 8.9 & 9.3 & 10.5 & 10.5 & $\ldots$ & $\ldots$ & $\ldots$ & $\ldots$ & $\ldots$ \\
\hline Other liabilities & 4.0 & 7.4 & 7.6 & 7.7 & $\ldots$ & $\ldots$ & $\ldots$ & $\ldots$ & $\ldots$ \\
\hline \multicolumn{10}{|l|}{ Memorandum items: } \\
\hline Net financial worth & 11.1 & 6.6 & 4.0 & 1.9 & $\ldots$ & $\ldots$ & $\ldots$ & $\ldots$ & $\ldots$ \\
\hline Fiscal reserve account & 12.1 & 11.2 & 8.5 & 6.4 & $\ldots$ & $\ldots$ & $\ldots$ & $\ldots$ & $\ldots$ \\
\hline Gross debt 6/ & 15.5 & 15.6 & 17.4 & 17.5 & 20.6 & 21.0 & 20.6 & 20.8 & 21.3 \\
\hline Foreign & 11.0 & 11.2 & 11.6 & 11.5 & 13.9 & 13.7 & 13.2 & 12.9 & 12.6 \\
\hline Domestic & 4.4 & 4.4 & 5.8 & 6.0 & 6.7 & 7.4 & 7.5 & 7.9 & 8.7 \\
\hline
\end{tabular}

Source: Ministry of Finance; IMF staff estimates.

$1 /$ On cash basis.

2/ Includes sales of fixed assets.

3/ Contribution to EU budget.

4/ The contingency reserve in 2010 includes BGN $527 \mathrm{mln}$ in arrears repayment; $218 \mathrm{mln}$ for road infrastructure; $45 \mathrm{mln}$ for railway infrastructure;

$116 \mathrm{mln}$ for subsidies (mostly agriculture); $142 \mathrm{mln}$ for social security; and $81 \mathrm{mln}$ for natural disasters.

$5 /$ Includes only acquisitions of nonfinancial assets, i.e. capital expenditure.

$6 /$ Includes guarantees. 
Table 6. Bulgaria: Monetary Accounts, 2008-16 (In billions of leva, unless otherwise stated)

\begin{tabular}{|c|c|c|c|c|c|c|c|c|c|}
\hline & $\begin{array}{c}2008 \\
\text { Dec. }\end{array}$ & $\begin{array}{l}2009 \\
\text { Dec. }\end{array}$ & $\begin{array}{c}2010 \\
\text { Dec. } \\
\text { Est. }\end{array}$ & $\begin{array}{c}2011 \\
\text { Dec. } \\
\text { Proj. }\end{array}$ & $\begin{array}{l}2012 \\
\text { Dec. } \\
\text { Proj. }\end{array}$ & $\begin{array}{l}2013 \\
\text { Dec. } \\
\text { Proj. }\end{array}$ & $\begin{array}{r}2014 \\
\text { Dec } \\
\text { Proj. }\end{array}$ & $\begin{array}{r}2015 \\
\text { Dec } \\
\text { Proj. }\end{array}$ & $\begin{array}{r}2016 \\
\text { Dec } \\
\text { Proj. }\end{array}$ \\
\hline \multicolumn{10}{|l|}{ Monetary Survey } \\
\hline Net foreign assets & 13.9 & 14.7 & 17.1 & 21.5 & 25.7 & 26.5 & 27.9 & 28.2 & 28.8 \\
\hline Net domestic assets & 44.8 & 47.4 & 49.2 & 52.6 & 56.2 & 61.3 & 67.9 & 75.5 & 84.7 \\
\hline Domestic credit & 44.5 & 47.6 & 50.0 & 53.3 & 56.9 & 62.0 & 68.5 & 76.1 & 85.2 \\
\hline General government & -5.2 & -4.0 & -2.3 & -1.6 & -1.0 & -0.5 & 0.2 & 0.7 & 1.5 \\
\hline Non-government & 49.7 & 51.6 & 52.3 & 54.9 & 57.9 & 62.5 & 68.3 & 75.4 & 83.7 \\
\hline Other items, net & 0.2 & -0.2 & -0.8 & -0.8 & -0.7 & -0.7 & -0.6 & -0.6 & -0.5 \\
\hline Broad money (M3) & 45.8 & 47.7 & 50.7 & 55.6 & 60.5 & 66.2 & 72.4 & 79.2 & 86.8 \\
\hline Currency outside banks & 8.0 & 7.1 & 7.4 & 7.7 & 8.3 & 8.8 & 9.3 & 9.9 & 10.6 \\
\hline Reserve money & 14.2 & 12.9 & 14.1 & 15.2 & 16.5 & 18.1 & 19.8 & 21.8 & 24.0 \\
\hline Deposits 2/ & 37.7 & 40.5 & 43.3 & 47.8 & 52.3 & 57.4 & 63.0 & 69.3 & 76.2 \\
\hline Lev & 19.6 & 19.7 & 22.1 & 24.5 & 26.7 & 29.1 & 31.8 & 34.8 & 38.1 \\
\hline Foreign currency & 18.1 & 20.8 & 21.2 & 23.3 & 25.6 & 28.3 & 31.2 & 34.5 & 38.1 \\
\hline Other Longer term items (not included in M3) $1 /$ & 12.9 & 14.4 & 15.6 & 17.3 & 18.9 & 20.3 & 21.9 & 24.1 & 26.5 \\
\hline \multicolumn{10}{|l|}{ Accounts of the Bulgarian National Bank } \\
\hline Net foreign assets & 24.8 & 23.9 & 24.0 & 26.6 & 29.9 & 30.6 & 31.9 & 32.4 & 33.2 \\
\hline Net domestic assets & -7.2 & -7.1 & -5.5 & -5.8 & -6.6 & -5.7 & -5.2 & -4.1 & -3.0 \\
\hline Net claims on government & -6.7 & -6.1 & -5.3 & -5.1 & -5.1 & -5.1 & -5.1 & -5.1 & -5.1 \\
\hline Net claims on rest of economy $2 /$ & -0.7 & -1.2 & -0.5 & -0.9 & -1.7 & -0.8 & -0.3 & 0.8 & 1.9 \\
\hline Other items, net & 0.2 & 0.2 & 0.2 & 0.3 & 0.3 & 0.3 & 0.3 & 0.2 & 0.2 \\
\hline Base money & 14.2 & 12.9 & 14.1 & 15.2 & 16.5 & 18.1 & 19.8 & 21.8 & 24.0 \\
\hline Currency in circulation & 8.0 & 7.1 & 7.4 & 7.7 & 8.3 & 8.8 & 9.3 & 9.9 & 9.3 \\
\hline Banks reserves & 6.2 & 5.8 & 6.8 & 7.5 & 8.3 & 9.3 & 10.5 & 11.9 & 14.7 \\
\hline Cash in vault & 1.2 & 0.9 & 0.9 & 0.9 & 0.9 & 1.0 & 1.1 & 1.2 & 1.3 \\
\hline Deposit money bank deposits with BNB & 5.0 & 4.9 & 5.8 & 6.6 & 7.4 & 8.3 & 9.4 & 10.7 & 13.4 \\
\hline Capital and reserves (not included in M0) & 3.4 & 3.8 & 4.3 & 5.6 & 6.7 & 6.8 & 6.8 & 6.5 & 6.2 \\
\hline \multicolumn{10}{|l|}{ Deposit money banks } \\
\hline Net foreign assets & -10.9 & -8.2 & -6.8 & -5.1 & -4.1 & -4.0 & -4.0 & -4.1 & -4.4 \\
\hline Net domestic assets & 51.3 & 53.3 & 54.1 & 57.4 & 61.0 & 66.1 & 72.7 & 80.4 & 89.5 \\
\hline Domestic credit & 51.2 & 53.6 & 55.2 & 58.4 & 62.0 & 67.1 & 73.6 & 81.2 & 90.3 \\
\hline Credit to government & 1.5 & 2.1 & 3.0 & 3.6 & 4.2 & 4.7 & 5.4 & 5.9 & 6.7 \\
\hline Credit to non-government & 49.6 & 51.5 & 52.2 & 54.8 & 57.8 & 62.4 & 68.2 & 75.3 & 83.6 \\
\hline Fixed assets and other items, net & 0.1 & -0.4 & -1.1 & -1.0 & -1.0 & -0.9 & -0.9 & -0.8 & -0.8 \\
\hline Reserves at $\mathrm{BNB}$, net & 6.1 & 5.8 & 6.8 & 6.3 & 5.8 & 6.5 & 7.2 & 8.1 & 9.0 \\
\hline Deposits $3 /$ & 37.0 & 39.3 & 42.8 & 46.9 & 50.5 & 56.5 & 62.8 & 70.1 & 78.0 \\
\hline Long term Deposits and Debt Securities (not included in M3) & 1.6 & 1.2 & 1.3 & 1.9 & 2.2 & 2.6 & 3.0 & 3.6 & 4.4 \\
\hline Capital and Reserves & 8.0 & 9.4 & 10.0 & 9.9 & 10.0 & 11.0 & 12.0 & 13.9 & 15.9 \\
\hline Memorandum items: & \multicolumn{9}{|c|}{ Annual percentage change } \\
\hline Base money & -0.1 & -8.7 & 9.0 & 8.0 & 8.5 & 9.2 & 9.7 & 10.0 & 10.0 \\
\hline Broad money & 8.8 & 4.2 & 6.4 & 9.5 & 8.9 & 9.3 & 9.3 & 9.5 & 9.6 \\
\hline Domestic non-government credit & 31.6 & 3.8 & 1.3 & 5.0 & 5.5 & 7.9 & 9.3 & 10.5 & 11.0 \\
\hline Domestic deposits & 8.8 & 7.6 & 6.9 & 10.2 & 9.3 & 9.9 & 9.8 & 10.0 & 10.0 \\
\hline Domestic currency & 6.9 & 0.8 & 11.8 & 10.7 & 8.7 & 9.3 & 9.2 & 9.4 & 9.4 \\
\hline Foreign currency & 10.9 & 15.0 & 2.2 & 9.7 & 9.8 & 10.4 & 10.3 & 10.5 & 10.5 \\
\hline Money multiplier & 3.2 & 3.7 & 3.6 & 3.9 & 4.3 & 4.3 & 4.4 & 4.4 & 4.8 \\
\hline Velocity (M3) & 1.4 & 1.4 & 1.4 & 1.4 & 1.3 & 1.3 & 1.3 & 1.2 & 1.2 \\
\hline GDP (millions of leva) & 69,295 & 68,322 & 70,474 & 75,492 & 80,762 & 85,677 & 91,067 & 96,984 & 103,385 \\
\hline
\end{tabular}

Sources: Bulgarlan National Bank, National Statls tlcs Instltute, and Fund staff estimates and projactlons

1/ Includes long term deposits and bank capital and reserves

$2 /$ Includes deposits at central bank.

$3 /$ Includes repurchase agreements. 
Table 7. Bulgaria: Financial Soundness Indicators, 2008-11

(In percent)

\begin{tabular}{|c|c|c|c|c|c|c|c|}
\hline & 2008 & $\begin{array}{r}2009 \\
\text { Dec }\end{array}$ & $\begin{array}{r}2010 \\
\text { Mar }\end{array}$ & $\begin{array}{r}2010 \\
\text { Jun }\end{array}$ & $\begin{array}{r}2010 \\
\text { Sep }\end{array}$ & $\begin{array}{r}2010 \\
\text { Dec }\end{array}$ & $\begin{array}{r}2011 \\
\text { March }\end{array}$ \\
\hline \multicolumn{8}{|l|}{ Core indicators } \\
\hline \multicolumn{8}{|l|}{ Capital adequacy } \\
\hline Capital to risk-weighted assets & 14.9 & 17.0 & 18.3 & 18.0 & 17.8 & 17.5 & 17.7 \\
\hline Tier 1 capital to risk-weighted assets & 11.2 & 14.0 & 15.2 & 15.2 & 15.3 & 15.2 & 15.4 \\
\hline \multicolumn{8}{|l|}{ Asset quality } \\
\hline Nonperforming loans to total gross loans & 2.5 & 6.4 & 7.8 & 9.5 & 10.6 & 11.9 & 12.9 \\
\hline Nonperforming loans net of provisions to capital & 4.3 & 15.1 & 18.3 & 22.4 & 24.8 & 28.1 & 30.8 \\
\hline Large exposures to capital & 70.3 & 58.7 & 60.4 & 66.8 & 71.7 & 87.9 & 88.9 \\
\hline \multicolumn{8}{|l|}{ Earnings and profitability } \\
\hline Return on assets & 2.1 & 1.1 & 1.0 & 1.0 & 0.9 & 0.9 & 0.9 \\
\hline Return on equity $1 /$ & 23.1 & 10.2 & 8.8 & 9.1 & 8.2 & 7.9 & 8.0 \\
\hline Net interest income to gross income & 75.1 & 75.1 & 75.6 & 75.3 & 75.0 & 74.2 & 75.9 \\
\hline Noninterest expense to gross income & 49.9 & 50.0 & 49.1 & 49.8 & 48.8 & 49.1 & 49.9 \\
\hline Personnel expense to total income & 19.0 & 18.4 & 18.5 & 18.4 & 18.2 & 17.8 & 18.7 \\
\hline Trading and fee income to total income & 23.9 & 23.6 & 24.0 & 24.1 & 24.2 & 24.7 & 22.5 \\
\hline \multicolumn{8}{|l|}{ Liquidity } \\
\hline Liquid assets to total assets & 19.1 & 18.8 & 19.1 & 19.0 & 19.0 & 20.9 & 20.9 \\
\hline Liquid assets to short-term liabilities & 26.6 & 26.6 & 26.8 & 26.8 & 26.9 & 30.1 & 30.6 \\
\hline Liquid assets to total liabilities & 22.6 & 21.8 & 22.1 & 22.0 & 21.9 & 24.2 & 24.3 \\
\hline \multicolumn{8}{|l|}{ Encouraged indicators } \\
\hline \multicolumn{8}{|l|}{ Deposit-taking institutions } \\
\hline Capital to assets $2 /$ & 8.5 & 10.8 & 11.0 & 10.9 & 10.7 & 10.5 & 10.6 \\
\hline Trading income to total income & 2.8 & 4.2 & 5.3 & 4.9 & 4.8 & 5.4 & 3.4 \\
\hline Personnel expenses to noninterest expenses & 38.2 & 36.9 & 37.7 & 37.0 & 37.3 & 36.3 & 37.5 \\
\hline Customer deposits to total (non-interbank) loans & 84.8 & 83.0 & 85.6 & 86.1 & 85.5 & 87.8 & 90.3 \\
\hline Foreign currency denominated loans to total loans & 56.9 & 58.6 & 59.5 & 60.1 & 60.9 & 61.3 & 61.6 \\
\hline Foreign currency denominated liabilities to total liabilities & 60.0 & 64.4 & 63.0 & 62.1 & 60.8 & 58.6 & 57.6 \\
\hline Net open foreign-exchange position $3 /$ & $\ldots$ & $\ldots$ & $\ldots$ & $\ldots$ & $\ldots$ & $\ldots$ & $\ldots$ \\
\hline
\end{tabular}

Source: Bulgarian National Bank.

1/ Return on equity is calculated with Tier I as denominator.

2/ Capital to assets is based on Tier I capital.

3/ The net open foreign-exchange position regulation was ended in 2005. 
Table 8. Bulgaria: External Financial Assets and Liabilities, 2008-16 (In millions of euro, unless otherwise indicated)

\begin{tabular}{|c|c|c|c|c|c|c|c|c|c|}
\hline & 2008 & 2009 & 2010 & $\begin{array}{l}2011 \\
\text { Proj. }\end{array}$ & $\begin{array}{l}2012 \\
\text { Proj. }\end{array}$ & $\begin{array}{l}2013 \\
\text { Proj. }\end{array}$ & $\begin{array}{l}2014 \\
\text { Proj. }\end{array}$ & $\begin{array}{l}2015 \\
\text { Proj. }\end{array}$ & $\begin{array}{l}2016 \\
\text { Proj. }\end{array}$ \\
\hline International investment position & $-34,559$ & $-35,579$ & $-35,185$ & $-35,900$ & $-35,055$ & $-35,002$ & $-35,243$ & $-35,858$ & $-37,050$ \\
\hline Financial assets & 21,248 & 22,269 & 23,069 & 24,609 & 27,344 & 28,816 & 30,596 & 31,945 & 33,545 \\
\hline Foreign direct investment & 1,034 & 936 & 1,112 & 1,305 & 1,510 & 1,728 & 1,961 & 2,208 & 2,472 \\
\hline Portfolio investment & 1,210 & 1,835 & 2,688 & 3,374 & 4,165 & 4,955 & 5,708 & 6,448 & 7,234 \\
\hline Other investments & 6,292 & 6,578 & 6,293 & 6,370 & 6,435 & 6,531 & 6,643 & 6,761 & 6,886 \\
\hline Gross international reserves $1 /$ & 12,713 & 12,919 & 12,977 & 13,560 & 15,234 & 15,601 & 16,285 & 16,528 & 16,953 \\
\hline Financial liabilities & 55,808 & 57,848 & 58,254 & 60,509 & 62,399 & 63,818 & 65,839 & 67,802 & 70,595 \\
\hline Foreign direct investment & 31,611 & 34,141 & 35,901 & 38,893 & 39,932 & 42,047 & 44,305 & 47,015 & 49,902 \\
\hline Equity & 18,984 & 20,679 & 22,807 & 24,533 & 26,394 & 28,509 & 30,767 & 33,477 & 36,364 \\
\hline Intercompany debt & 12,627 & 13,461 & 13,094 & 14,360 & 13,538 & 13,538 & 13,538 & 13,538 & 13,538 \\
\hline Portfolio investment & 1,861 & 1,780 & 1,664 & 1,503 & 1,518 & 1,511 & 1,515 & 1,517 & 1,548 \\
\hline Loans & 14,499 & 14,896 & 14,511 & 14,582 & 15,432 & 14,632 & 14,279 & 13,374 & 13,071 \\
\hline BNB 1/ & 0 & 0 & 0 & 0 & 0 & 0 & 0 & 0 & 0 \\
\hline General government & 1,558 & 1,806 & 1,869 & 2,076 & 3,227 & 2,378 & 1,936 & 898 & 390 \\
\hline Banks & 2,947 & 2,923 & 1,999 & 1,735 & 1,338 & 1,282 & 1,261 & 1,271 & 1,314 \\
\hline Other sectors & 9,994 & 10,167 & 10,643 & 10,771 & 10,868 & 10,972 & 11,082 & 11,205 & 11,367 \\
\hline Other liabilities & 7,837 & 7,031 & 6,178 & 5,531 & 5,517 & 5,628 & 5,740 & 5,898 & 6,074 \\
\hline \multicolumn{10}{|l|}{ Memorandum items: } \\
\hline GIR (in percent of GDP) & 35.9 & 37.0 & 36.0 & 35.2 & 37.1 & 35.8 & 35.0 & 33.4 & 32.1 \\
\hline GIR (in percent of short-term debt, at remaining maturity) & 71.7 & 78.9 & 91.2 & 98.7 & 107.2 & 111.6 & 103.5 & 103.4 & 113.7 \\
\hline GIR (in months of next year's imports) & 7.8 & 7.3 & 6.6 & 6.3 & 6.6 & 6.4 & 6.3 & 6.4 & 6.1 \\
\hline NIR (in percent of GDP) & 35.9 & 37.0 & 36.0 & 35.2 & 37.1 & 35.8 & 35.0 & 33.4 & 32.1 \\
\hline Gross external debt (in percent of GDP) & 104.9 & 108.0 & 101.8 & 92.8 & 89.3 & 82.4 & 76.8 & 70.6 & 66.1 \\
\hline Public $2 /$ & 7.1 & 8.1 & 8.0 & 7.6 & 10.0 & 7.4 & 6.0 & 3.6 & 2.4 \\
\hline Private & 97.7 & 99.9 & 93.8 & 85.2 & 79.3 & 74.9 & 70.8 & 67.0 & 63.6 \\
\hline Short-term & 37.1 & 35.3 & 31.9 & 27.8 & 25.9 & 25.0 & 23.9 & 22.9 & 22.2 \\
\hline Long-term & 60.7 & 64.6 & 61.9 & 57.5 & 53.4 & 49.9 & 46.9 & 44.1 & 41.5 \\
\hline Gross external debt (in percent of exports of GNFS) & 180.6 & 227.0 & 175.7 & 149.6 & 143.6 & 132.7 & 126.3 & 116.7 & 109.5 \\
\hline Net international investment position (in percent of GDP) & -97.5 & -101.9 & -97.6 & -93.1 & -85.5 & -80.2 & -75.8 & -72.4 & -70.2 \\
\hline GDP & 35,430 & 34,932 & 36,033 & 38,544 & 41,016 & 43,637 & 46,472 & 49,539 & 52,809 \\
\hline
\end{tabular}

Source: BNB; NSI; IMF staff estimates.

$1 /$ It includes SDR allocation.

2/ General government. It does not include private sector publicly-guaranteed debt.

Sources: BNB; NSI; and Fund staff estimates and projections. 


\section{Appendix I. External and Public Debt Sustainability Analyses}

Private external debt increased rapidly during the last decade. Since 2003, private sector debt increased from about 20 percent of GDP to more than 90 percent as of end-2010. On the other hand, the public sector reduced its external debt from 35 percent of GDP in 2003 to 8 percent in 2010. As a result, public debt represents less than 8 percent of total external debt as of end-2010.
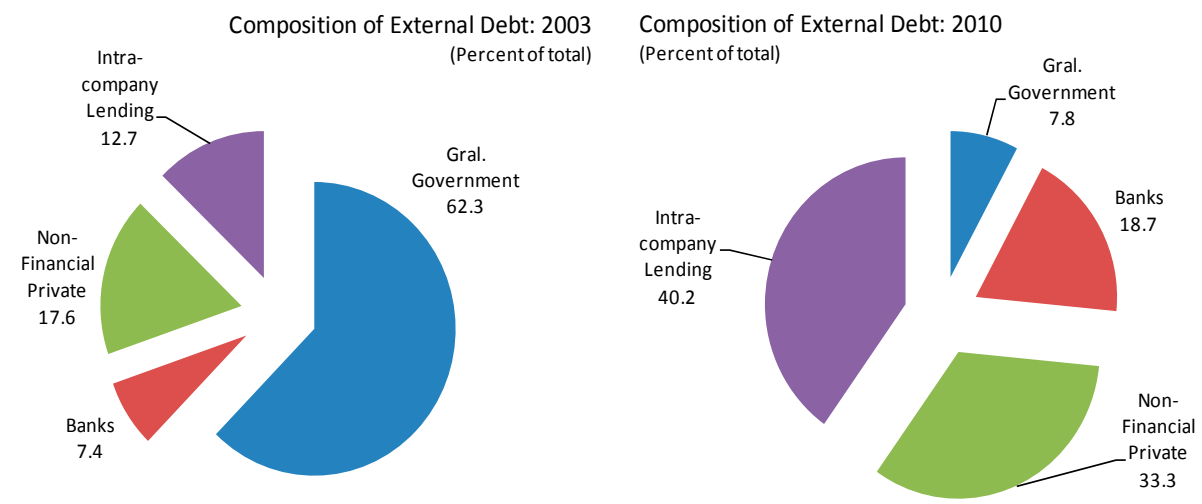

The external adjustment associated with the global crisis, though, has started a gradual deleveraging process. External debt peaked in 2009 at 108 percent of GDP. The rapid adjustment in the current account deficit, though, has already resulted in a reduction of external debt to $93^{1} / 2$ percent of GDP at end-March. Medium term current account projections suggest that this incipient deleveraging will continue in coming years, taking external debt to less than 70 percent of GDP by 2016. Remarkably, deleveraging in the baseline scenario takes place at a slower phase than in the historical scenario, which shows that external debt may fall to about 60 percent of GDP by 2016. This is related to relative conservative growth assumptions compared to the historical average.

\section{About 40 percent of the external debt is intra-company lending, which reduces rollover} risks. Intra-company lending has been remarkably stable during the global financial crisis; as companies have been able to tap new financing for larger amounts than the scheduled amortizations, i.e. rollover rates for the period 2008-10 averaged 170 percent.

\section{Different real and financial shocks may disrupt medium-term trajectories, but the} deleveraging process seems to be anchored over the medium term. Persistent $1 / 4$ standard deviation shocks applied to the interest rate, the growth rate and the current account deficit would shift the trajectory of the external debt upwards, taking it to 83 percent of GDP by 2016, which would still imply a significant deleveraging in coming years.

Public debt remains at manageable levels. With gross debt below 20 percent of GDP, Bulgaria's indebtedness of the general government is low by international standards. Assuming shocks to the baseline forecast, the debt ratio could increase significantly, but remains below 40 percent of GDP in all scenarios considered. However, risks remain from unaccounted contingent liabilities and worse-than-assumed downside scenarios. 
Figure 1. Bulgaria: External Debt Sustainability: Bound Tests 1/2/ (External debt in percent of GDP)

Baseline and historical scenarios

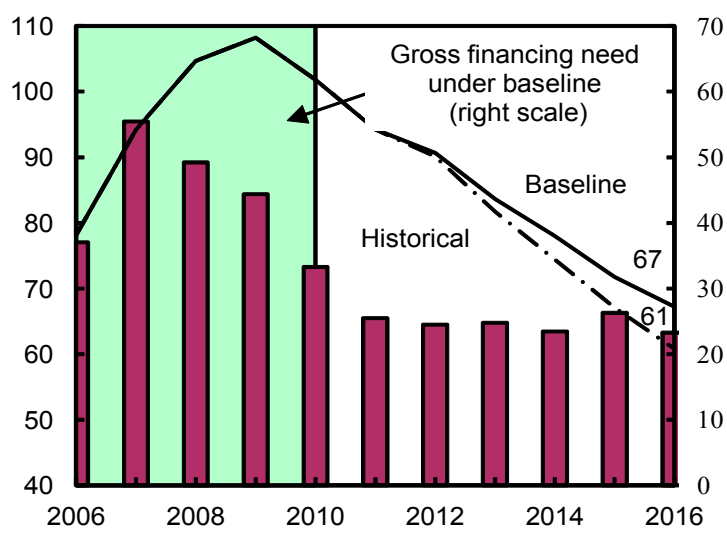

Growth shock (in percent per year)

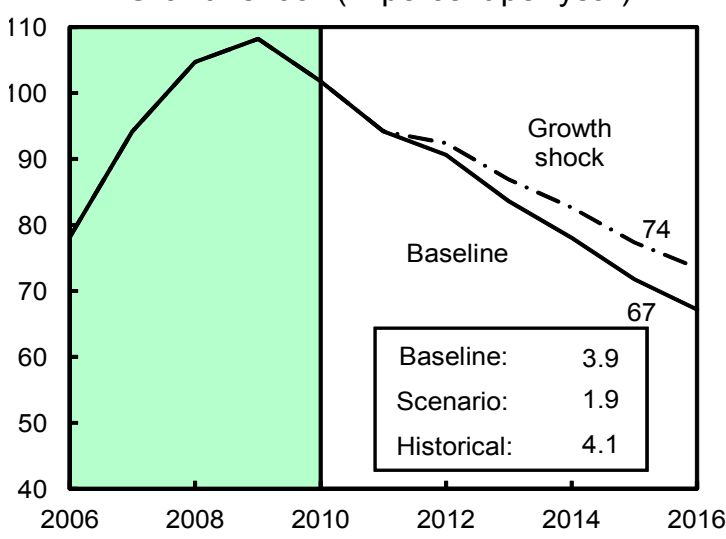

Combined shock $3 /$

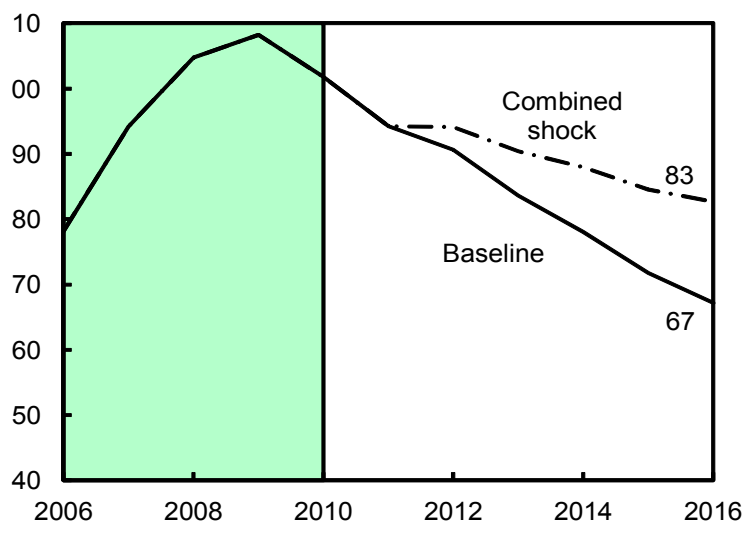

Interest rate shock (in percent)

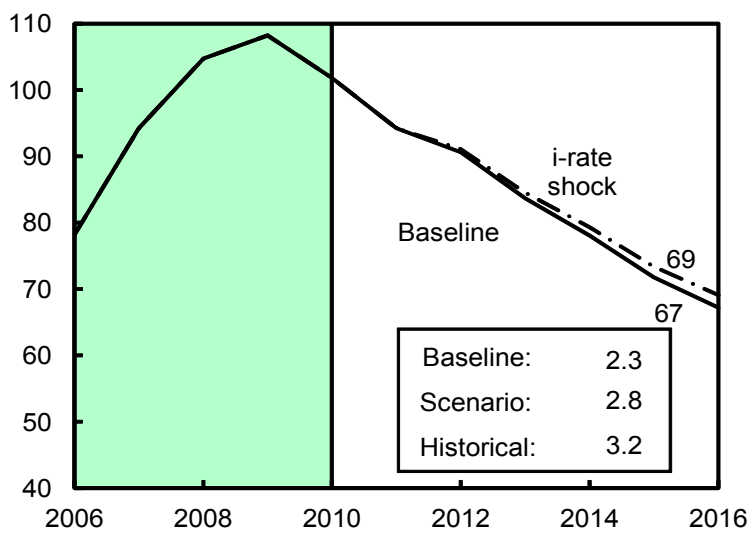

Non-interest current account shock (in percent of GDP)

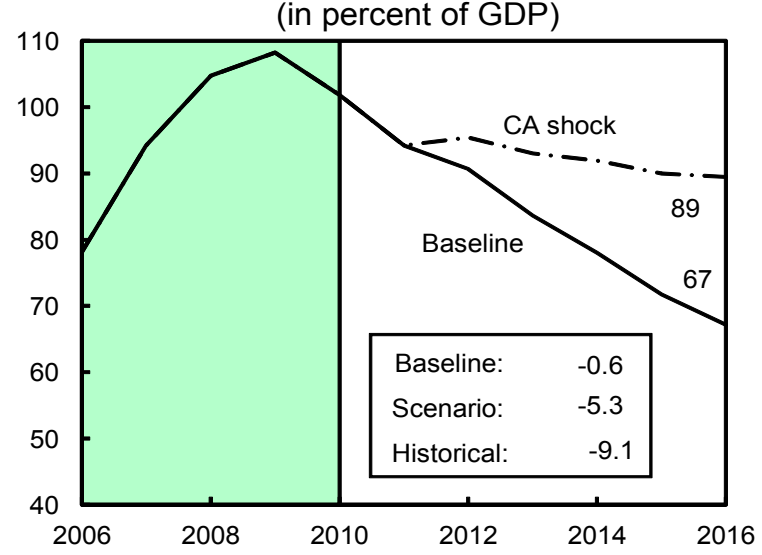

Real depreciation shock 4/

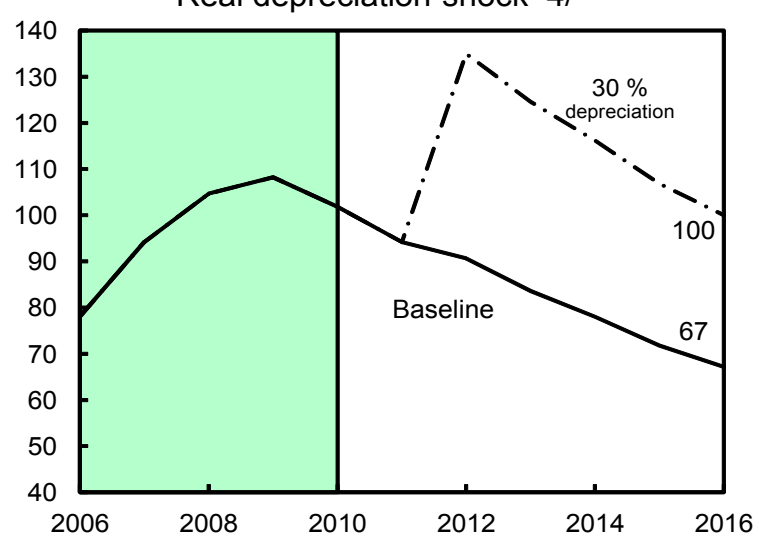

Sources: International Monetary Fund, Country desk data, and staff estimates.

$1 /$ Shaded areas represent actual data. Individual shocks are permanent one-half standard deviation shocks. Figures in the boxes represent average projections for the respective variables in the baseline and scenario being presented. Ten-year historical average for the variable is also shown.

2/ For historical scenarios, the historical averages are calculated over the ten-year period, and the information is used to project debt dynamics five years ahead.

3/ Permanent 1/4 standard deviation shocks applied to real interest rate, growth rate, and current account balance.

4/ One-time real depreciation of 30 percent occurs in 2012. 
Figure 2. Bulgaria: Public Debt Sustainability: Bound Tests 1/ (Public debt in percent of GDP)

Baseline and historical scenarios

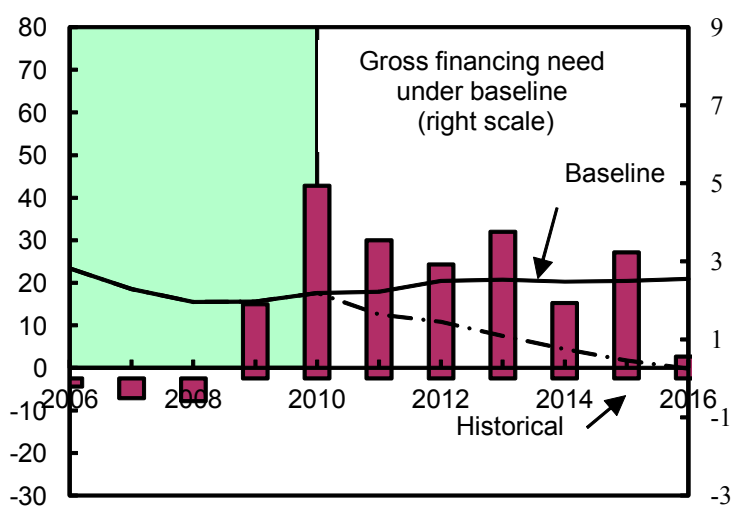

Growth shock (in percent per year)

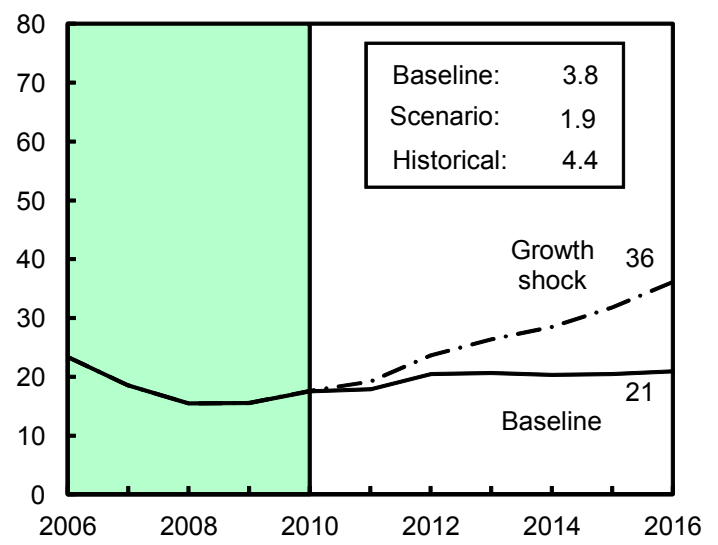

Combined shock 2/

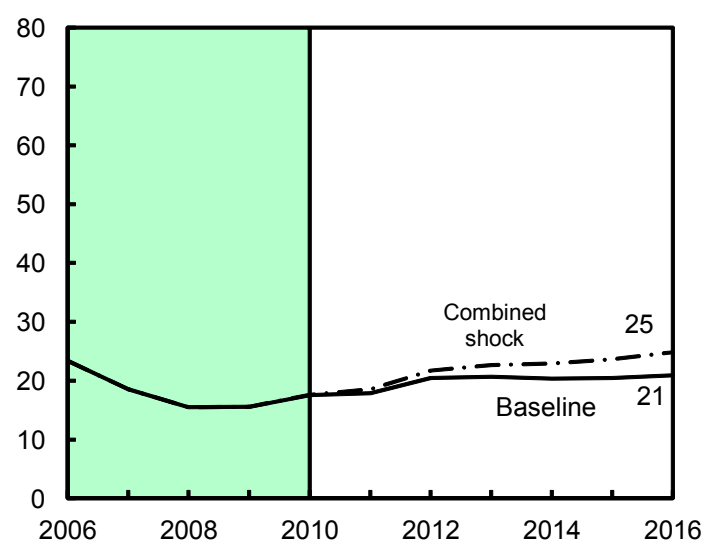

Interest rate shock (in percent)

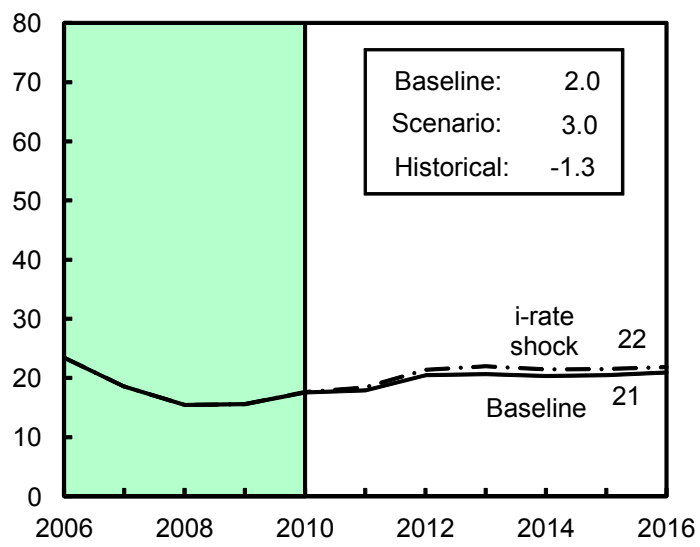

Primary balance shock (in percent of GDP) and no policy change scenario (constant primary balance)

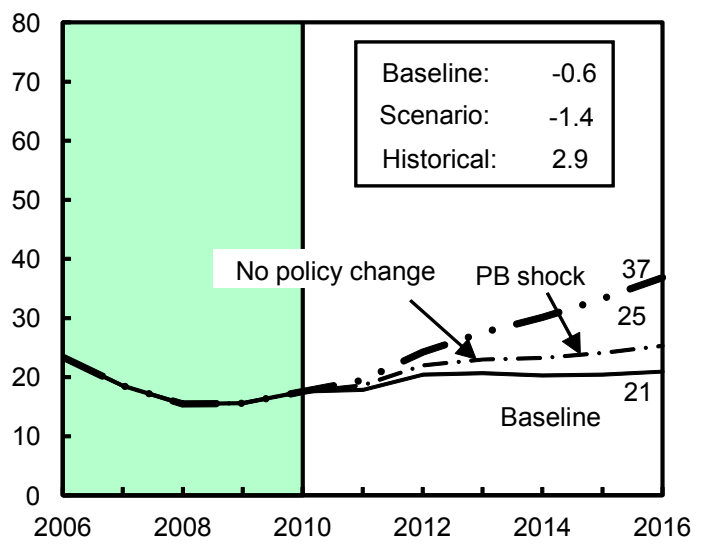

Real depreciation and contingent liabilities shocks $3 /$

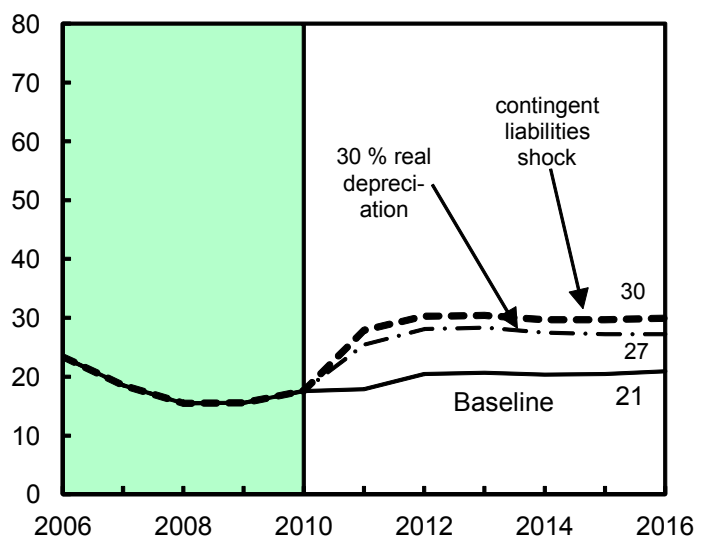

Sources: International Monetary Fund, country desk data, and staff estimates.

$1 /$ Shaded areas represent actual data. Individual shocks are permanent one-half standard deviation shocks. Figures in the boxes represent average projections for the respective variables in the baseline and scenario being presented. Ten-year historical average for the variable is also shown.

2/ Permanent 1/4 standard deviation shocks applied to real interest rate, growth rate, and primary balance.

$3 /$ One-time real depreciation of 30 percent and 10 percent of GDP shock to contingent liabilities occur in 2010 , with real depreciation defined as nominal depreciation (measured by percentage fall in dollar value of local currency) minus domestic inflation (based on GDP deflator). 
Table 1. Bulgarla: External Debt Sustalnabllity Framework, 2006-16

(In percent of GDP, unless otherwise indicated)

\begin{tabular}{|c|c|c|c|c|c|c|c|c|c|c|c|c|}
\hline & \multicolumn{5}{|c|}{ Actual } & \multicolumn{7}{|c|}{ Projections } \\
\hline & 2006 & 2007 & 2008 & 2009 & 2010 & 2011 & 2012 & 2013 & 2014 & 2015 & 2016 & Debt-stabilizing \\
\hline Baseline: External dobt & 82.0 & 94.3 & 104.9 & 108.0 & 101.8 & 94.2 & 90.6 & 83.6 & 78.0 & 71.8 & 67.2 & 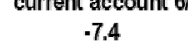 \\
\hline Change in external debt & 15.3 & 12.3 & 10.6 & 3.1 & -6.2 & -7.6 & -3.6 & -7.0 & -5.6 & -6.3 & -4.6 & \\
\hline Identified external debt-creating flows $(4+8+9)$ & -6.8 & -7.1 & -4.4 & 11.5 & -2.4 & -6.1 & -6.1 & -6.2 & -5.2 & -4.8 & -3.7 & \\
\hline Current account deficit, excluding inter est payments & 15.7 & 28.0 & 20.5 & 7.0 & -0.5 & -1.7 & -1.0 & -0.5 & 0.4 & 1.3 & 2.8 & \\
\hline Deficit in balance of goods and services & 17.5 & 19.7 & 20.5 & 8.2 & 1.4 & 0.5 & 1.0 & 1.6 & 2.0 & 2.4 & 2.5 & \\
\hline Exports & 61.2 & 59.4 & 58.1 & 47.6 & 57.9 & 62.1 & 62.2 & 62.1 & 60.8 & 60.5 & 60.4 & \\
\hline Imports & 78.7 & 79.1 & 78.6 & 55.8 & 59.3 & 62.6 & 63.2 & 63.7 & 62.9 & 62.9 & 62.8 & \\
\hline Net non-debt creating capital inflows (negative) & -15.8 & -20.1 & -9.4 & -4.9 & -5.3 & -4.0 & -4.0 & -4.3 & -4.4 & -5.0 & -5.0 & \\
\hline Automatic debt dynamics $1 /$ & -6.8 & -15.0 & -15.5 & 9.4 & 3.3 & -0.4 & -1.1 & -1.3 & -1.2 & -1.2 & -1.4 & \\
\hline Contribution from nominal interest rate & 1.8 & 2.3 & 2.5 & 1.9 & 1.5 & 2.2 & 2.0 & 2.1 & 1.9 & 1.8 & 1.3 & \\
\hline Contribution from real GDP growth & -3.8 & -4.2 & -4.7 & 6.2 & -0.2 & -2.7 & -3.1 & -3.4 & -3.2 & -3.0 & -2.7 & \\
\hline Contribution from price and exchange rate changes 2 & -4.8 & -13.2 & -13.3 & 1.3 & 2.0 & & $\ldots$ & & $\ldots$ & $\ldots$ & $\ldots$ & \\
\hline Residual, incl. change in gross foreign assets (2-3) $3 i$ & 22.1 & 19.4 & 15.0 & -8.4 & -3.8 & -1.5 & 2.5 & -0.8 & -0.4 & -1.5 & -0.9 & \\
\hline External debt-to-exports ratio (in percent) & 134.0 & 158.8 & 180.6 & 227.1 & 175.7 & 151.8 & 145.7 & 134.7 & 128.3 & 118.6 & 111.3 & \\
\hline Gross external financing need (in billions of US dollars) $4 /$ & 12.3 & 23.4 & 25.7 & 21.6 & 15.9 & 14.0 & 14.4 & 15.3 & 15.3 & 18.1 & 17.0 & \\
\hline in percent of GDP & 37.0 & 55.4 & 49.2 & 44.4 & 33.3 & 25.5 & 24.5 & 24.8 & 23.5 & 26.3 & 23.3 & \\
\hline Scenario with key variables at their historical averages 5 ? & & & & & & 94.2 & 90.1 & 81.7 & 74.4 & 67.1 & 60.8 & -14.9 \\
\hline \multicolumn{13}{|l|}{ Kөy Macroeconomic Assumptions Underlying Baseline } \\
\hline Real GDP growth (in percent) & 6.5 & 6.4 & 6.2 & -5.5 & 0.2 & 3.0 & 3.5 & 4.0 & 4.0 & 4.0 & 4.0 & \\
\hline GDP deflator in US dollars (change in percent) & 7.7 & 19.2 & 16.4 & -1.3 & -1.9 & 11.6 & 3.1 & 1.4 & 1.5 & 1.7 & 1.7 & \\
\hline Nominal external inter est rate (in percent) & 3.1 & 3.6 & 3.3 & 1.7 & 1.3 & 2.5 & 2.3 & 2.4 & 2.4 & 2.4 & 2.0 & \\
\hline Growth of exports (US dollar terms, in percent) & 25.3 & 23.1 & 20.9 & -23.6 & 19.7 & 23.2 & 7.0 & 5.2 & 3.4 & 5.2 & 5.5 & \\
\hline Growth of imports (US dollar terms, in percent) & 26.4 & 35.6 & 15.5 & -33.8 & 4.5 & 21.2 & 7.9 & 6.1 & 4.2 & 5.8 & 5.6 & \\
\hline Current account balance, excluding interest payments & -15.7 & -28.0 & -20.5 & -7.0 & 0.5 & 1.7 & 1.0 & 0.5 & -0.4 & -1.3 & -2.6 & \\
\hline Net non-debt creating capital inflows & 15.8 & 20.1 & 9.4 & 4.9 & 5.3 & 4.0 & 4.0 & 4.3 & 4.4 & 5.0 & 5.0 & \\
\hline
\end{tabular}

Source: Bulgaria National Bank; IMF staff estimates.

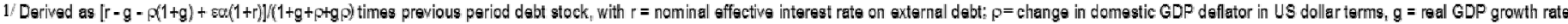
$8=$ nominal appreciation (increase in dellar value of damestic currency), and $\alpha=$ share of damestic-currency denominated dabt in total external dabt.

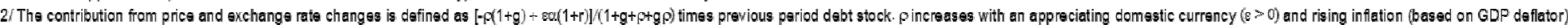

$3 /$ For projection, line includes the impact of price and exchange rate changes.

4/ Defined as current account deficit, plus amortization on medium-and lang-term dabt, plus short-term debt at end af previous period.

5/ The key variables include real GDP growth; naminal intarest rate; dollar deflator growth; and both non-intarest current account and non-debt inflows in percent of GDP.

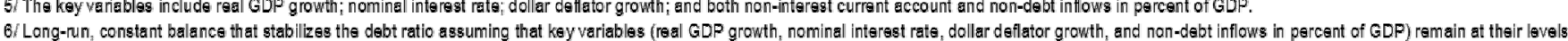

of the last projection year. 
Table 2. Bulgaria: Public Sector Debt Sustainability Framework, 2008-16 (In percent of GDP, unless otherwise indicated)

\begin{tabular}{|c|c|c|c|c|c|c|c|c|c|c|}
\hline & \multicolumn{3}{|c|}{ Actual } & \multicolumn{6}{|c|}{ Projections } & \multirow{4}{*}{$\begin{array}{c}\text { Debt-stabilizing } \\
\text { primary } \\
\text { balance } 10 / \\
0.6\end{array}$} \\
\hline & 2008 & 2009 & 2010 & 2011 & 2012 & 2013 & 2014 & 2015 & 2016 & \\
\hline & & & & & & & & & & \\
\hline Baseline: Public sector debt 1/ & 15.5 & 15.6 & 17.4 & 17.5 & 20.6 & 21.0 & 20.6 & 20.8 & 21.3 & \\
\hline Of which foreign-currency denominated & 11.0 & 11.2 & 11.6 & 11.5 & 13.9 & 13.7 & 13.2 & 12.9 & 12.6 & \\
\hline Change in public sector debt & -3.1 & 0.1 & 1.8 & 0.2 & 3.0 & 0.5 & -0.4 & 0.1 & 0.5 & \\
\hline Identified debt-creating flows $(4+7+12)$ & -7.4 & -1.5 & 1.8 & 0.6 & -0.4 & -1.1 & -1.6 & -1.4 & -0.7 & \\
\hline Primary deficit & -3.7 & 0.2 & 3.3 & 1.7 & 1.0 & 0.2 & 0.1 & 0.0 & -0.2 & \\
\hline Revenue and grants & 38.0 & 35.3 & 32.7 & 32.7 & 33.5 & 34.1 & 33.6 & 33.4 & 33.2 & \\
\hline Primary (noninterest) expenditure & 34.3 & 35.4 & 36.0 & 34.4 & 34.5 & 34.3 & 33.6 & 33.4 & 33.0 & \\
\hline Automatic debt dynamics $2 /$ & -2.4 & 0.2 & 0.2 & -0.2 & -0.3 & -0.2 & -0.6 & -0.4 & -0.5 & \\
\hline Contribution from interest rate/growth differential $3 /$ & -1.6 & 0.9 & 0.2 & -0.2 & -0.3 & -0.2 & -0.6 & -0.4 & -0.5 & \\
\hline Of which contribution from real interest rate & -0.6 & 0.1 & 0.2 & 0.1 & 0.3 & 0.6 & 0.4 & 0.3 & 0.3 & \\
\hline Of which contribution from real GDP growth & -1.0 & 0.8 & 0.0 & -0.3 & -0.7 & -0.8 & -1.0 & -0.8 & -0.8 & \\
\hline Contribution from exchange rate depreciation $4 /$ & -0.9 & -0.7 & $\ldots$ & $\ldots$ & $\ldots$ & $\ldots$ & $\ldots$ & $\ldots$ & $\ldots$ & \\
\hline Other identified debt-creating flows & 1.3 & 1.9 & 1.7 & 0.9 & 1.1 & 1.1 & 1.1 & 1.0 & 0.0 & \\
\hline Of which: Privatization receipts (negative) & -0.8 & -0.1 & -0.1 & -0.6 & -0.2 & -0.1 & 0.0 & 0.0 & 0.0 & \\
\hline Residual, including asset changes $(2-3) 5 /$ & 4.3 & 1.7 & 0.0 & -0.4 & 3.4 & 1.6 & 1.2 & 1.5 & 1.2 & \\
\hline Public sector debt-to-revenue ratio $1 /$ & 40.6 & 44.2 & 53.1 & 53.7 & 61.5 & 61.7 & 61.5 & 62.1 & 64.1 & \\
\hline Scenario with key variables at their historical averages $7 /$ & $\ldots$ & $\ldots$ & 17.6 & 12.5 & 10.8 & 7.5 & 4.4 & 1.7 & -0.2 & 0.0 \\
\hline Scenario with no policy change (constant primary balance) in 2010-2016 & $\ldots$ & $\ldots$ & 17.6 & 19.5 & 24.2 & 27.5 & 30.1 & 33.3 & 36.9 & -0.9 \\
\hline \multicolumn{11}{|l|}{ Key Macroeconomic and Fiscal Assumptions Underlying Baseline 8/ } \\
\hline Real GDP growth (in percent) & 6.0 & -5.0 & 0.0 & 2.0 & 4.0 & 4.0 & 5.0 & 3.9 & 4.0 & \\
\hline Average nominal interest rate on public debt (in percent) $9 /$ & 5.2 & 4.9 & 4.6 & 4.7 & 5.4 & 5.6 & 4.6 & 4.4 & 4.1 & \\
\hline Average real interest rate (nominal rate minus change in GDP deflator, in percent) & -3.2 & 0.6 & 1.6 & 0.7 & 2.0 & 3.3 & 2.2 & 1.9 & 1.6 & \\
\hline Nominal appreciation (increase in US dollar value of local currency, in percent) & 7.0 & 5.7 & & $\ldots$ & & 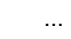 & $\ldots$ & $\ldots$ & $\ldots$ & \\
\hline Inflation rate (GDP deflator, in percent) & 8.4 & 4.3 & 3.0 & 4.0 & 3.4 & 2.3 & 2.4 & 2.5 & 2.5 & \\
\hline Growth of real primary spending (deflated by GDP deflator, in percent) & 7.6 & -2.5 & 1.7 & -1.6 & 3.9 & 3.1 & 1.8 & 3.2 & 2.7 & \\
\hline
\end{tabular}

Sources: WEO; and Fund staff estimates and projections.

$1 /$ Gross debt including guarantees.

$2 /$ Derived as $[(r-\pi(1+g)-g+\alpha \varepsilon(1+r)] /(1+g+\pi+g \pi))$ times previous period debt ratio, with $r=$ interest rate; $\pi=$ growth rate of GDP deflator; $g=$ real GDP growth rate; $\alpha=$ share of foreign-currency

denominated debt; and $\varepsilon=$ nominal exchange rate depreciation (measured by increase in local currency value of U.S. dollar).

$3 /$ The real interest rate contribution is derived from the denominator in footnote $2 /$ as $r-\pi(1+g)$ and the real growth contribution as $-g$

$4 /$ The exchange rate contribution is derived from the numerator in footnote $2 /$ as $\alpha \varepsilon(1+r)$.

$5 /$ For projections, this line includes exchange rate changes.

$6 /$ Defined as public sector deficit, plus amortization of medium and long-term public sector debt, plus short-term debt at end of previous period.

7/ The key variables include real GDP growth; real interest rate; and primary balance in percent of GDP.

8/ Note: Based on WEO and may differ from staff projections in the report.

9/ Derived as nominal interest expenditure divided by previous period debt stock.

10/ Assumes that key variables (real GDP growth, real interest rate, and other identified debt-creating flows) remain at the level of the last projection year 


\section{INTERNATIONAL MONETARY FUND}

\section{BULGARIA}

Staff Report for the 2011 Article IV Consultation-Informational Annex

Prepared by the European Department

June 15, 2011

Contents

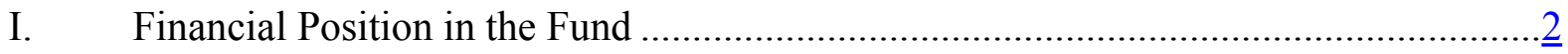

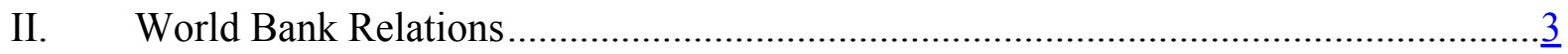

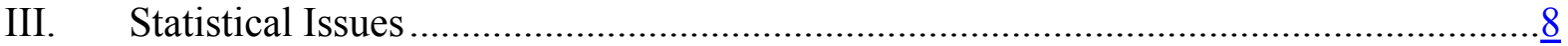




\section{Bulgaria: Financial Position in the Fund}

\section{(As of April 30, 2011)}

I. Membership Status: Joined: September 25, 1990;

$\underline{\text { Article VIII }}$

II. General Resources Account:

640.20

\%Quota

Quota

606.22

100.00

Fund holdings of currency (Exchange Rate)

94.69

$\underline{\text { Reserve Tranche Position }}$

34.01

5.31

III. SDR Department:

SDR Million

\%Allocation

$\underline{\text { Net cumulative allocation }}$

610.88

100.00

Holdings

610.89

100.00

IV. Outstanding Purchases and Loans: None

V. Latest Financial Arrangements:

Date of

Type

Stand-By

Stand-By

$\mathrm{EFF}$

\section{Arrangement}

Aug 06, 2004

Feb 27, 2002

Sep 25, 1998
Expiration

$\underline{\text { Date }}$

Mar 31, 2007

Mar 15, 2004

Sep 24, 2001
Amount Approved

$\underline{\text { (SDR Million) }}$

100.00

240.00

627.62
Amount Drawn

(SDR Million)

240.00

627.62

VI. Projected Payments to Fund ${ }^{1 /}$

(SDR Million; based on existing use of resources and present holdings of SDRs):

\begin{tabular}{llllll} 
& \multicolumn{6}{c}{ Forthcoming } & & \\
\cline { 2 - 5 } & $\underline{2011}$ & $\underline{2012}$ & $\underline{2013}$ & $\underline{2014}$ & $\underline{2015}$ \\
$\begin{array}{l}\text { Principal } \\
\text { Charges/Interest }\end{array}$ & $\underline{0.01}$ & $\underline{0.01}$ & $\underline{0.01}$ & $\underline{0.01}$ & $\underline{0.01}$ \\
Total & $\underline{0.01}$ & $\underline{0.01}$ & $\underline{0.01}$ & $\underline{0.01}$ & $\underline{0.01}$
\end{tabular}

${ }^{1 /}$ When a member has overdue financial obligations outstanding for more than three months, the amount of such arrears will be shown in this section.

VII. Implementation of HIPC Initiative: Not Applicable

VIII. Implementation of Multilateral Debt Relief Initiative (MDRI): Not Applicable

\section{Exchange Arrangements}

The currency of Bulgaria is the lev. Since July 1, 1997, the Bulgarian National Bank has operated a currency board arrangement. From July 1, 1997 to December 31, 1998, the lev was pegged to the Deutsche Mark at BGN 1000 per Deutsche Mark. Since January 1, 1999 the lev has been pegged to the euro at BGN 1.95583 per euro. Bulgaria joined the European Union (EU) on January 1, 2007. Bulgaria has accepted the obligations of Article VIII, Sections 2-4, and maintains an exchange system free of restriction on the making of payments and transfers for current international transfers.

\section{Resident Representative}

Mr. Lybek is the Regional Resident Representative, based in Bucharest. He took up the position on March 31, 2009. 


\section{BULGARIA: IMF-WORLD BANK RELATIONS}

\section{A. Partnership in Bulgaria's Development Strategy}

1. The World Bank has been leading the policy dialogue in structural and institutional reforms aimed at Bulgaria's successful EU integration and convergence. On May 17, 2011 the Board of Directors discussed the Country Partnership Strategy (CPS) of the Bank which outlined the roadmap for the Bank's country support for the period 2011-13. The CPS maintains a strong focus on Bulgaria making the most of its EU membership. It aims to partner with Bulgaria in strengthening national institutions and capacity to meet EU targets and in accelerating the absorption of EU grant funds. The objective of the CPS is to support Bulgaria in strengthening institutions and policies to achieve smart, sustainable, and inclusive growth. The CPS proposes a program dominated by knowledge and advisory services complemented by a modest lending program. World Bank knowledge and advisory services would focus on policy reforms, sector strategies and strengthening institutional capacity for increased EU funds absorption. Activities within the ongoing lending portfolio from the previous CPS are being also realigned to support Bulgaria's EU funds absorption priority. A railway reform support financing package composed of a series of three DPLs and an investment loan complementary to EU funding are included in the indicative lending program. World Bank potential financial support will be discussed upon the Government's request, with priority given to results based lending. The Bank will continue to undertake substantial knowledge and advisory services on policy reforms in select sectors and themes of Bulgaria's National Reform Program 2011-2015 such as innovation, education, business regulation, transport, and water, green growth, and social inclusion.

\section{B. IMF-World Bank Collaboration in Specific Areas}

2. The Fund team led by Ms. Purfield (mission chief) met with the World Bank Bulgaria team led by Mr. Harrold (Country Director of Central/South Europe and Baltics) in October 2010, to identify macro-critical structural reforms and to coordinate the two teams' work for the period October 2010-September 2011. A meeting was also held with the WB country manager, Mr. Repnik (October 1) in Bulgaria. This memo has been updated in the context of discussions for the Article IV consultation

\section{Bulgaria's main macroeconomic challenges are to maintain confidence in the} currency board arrangement by pursuing prudent fiscal policies, ensuring financial system stability, and shifting growth towards the tradable sector. Fiscal discipline will be key to supporting the currency board arrangement. Continued prudent regulation and adequate capital buffers will help maintain financial system stability, while improvements in the business climate will facilitate more sustainable tradable-based growth.

4. Based on this shared assessment, the teams identified five structural reform areas as macrocritical in view of their central role in achieving fiscal consolidation and enhancing growth. 
- $\quad$ EU funds absorption. Increased absorption of EU funds through improvements of administrative capacity and upgrading planning, execution, and monitoring systems will play a vital role. Rationalization of public administration through elimination of unnecessary or duplicated units and restructuring staff will also be important.

- $\quad$ Pension reform. The combination of large pension increases and reductions in social security contributions rates in the past has widened the gap between pension contributions and expenditures. Key elements of reform are: (i) slowing of pension increases; (ii) adjustment of pension parameters; (iii) addressing underreporting of insurable income.

- Healthcare reform. Mispricing and other distorted incentives have created financing pressures for the public health insurance fund, calling for a comprehensive reform focusing on efficiency and quality of the system - including through rationalizing inpatient care.

- Education reform. Building on past achievement, education reforms should focus on improving results. The areas of reform include measures to enhance the quality of student learning and to improve access to education.

- Shifting growth towards the tradable sector. With the end of the domestic demand boom, the engine of Bulgaria's growth will need to shift towards exports. Moderate wage growth, improved labor market flexibility, and strengthening the business environment by cutting red tape and reducing the regulatory costs for doing business are called for to facilitate the shift.

- Development of basic infrastructure and energy. Sustaining development of basic infrastructure and energy are a high priority to reduce costs of the transport network, to strengthen energy security, and hence improve competitiveness of the economy.

5. The teams agreed that the Bank and the Fund share responsibility on financial sector issues, revenue administration, and pension reforms, while the Bank will lead EU funds absorption, basic infrastructure, business environment, education reforms, and social inclusion. Both teams will keep the other apprised of upcoming missions and assessments. World Bank country economists participated in both the October 2010 IMF Staff Visit and the May 2011 Article IV Consultation and the IMF have assisted with World Bank work on competitiveness. 
Appendix 1. Bulgaria: Bank and Fund activities in macro-critical structural reform areas, May 2010- June 2011.

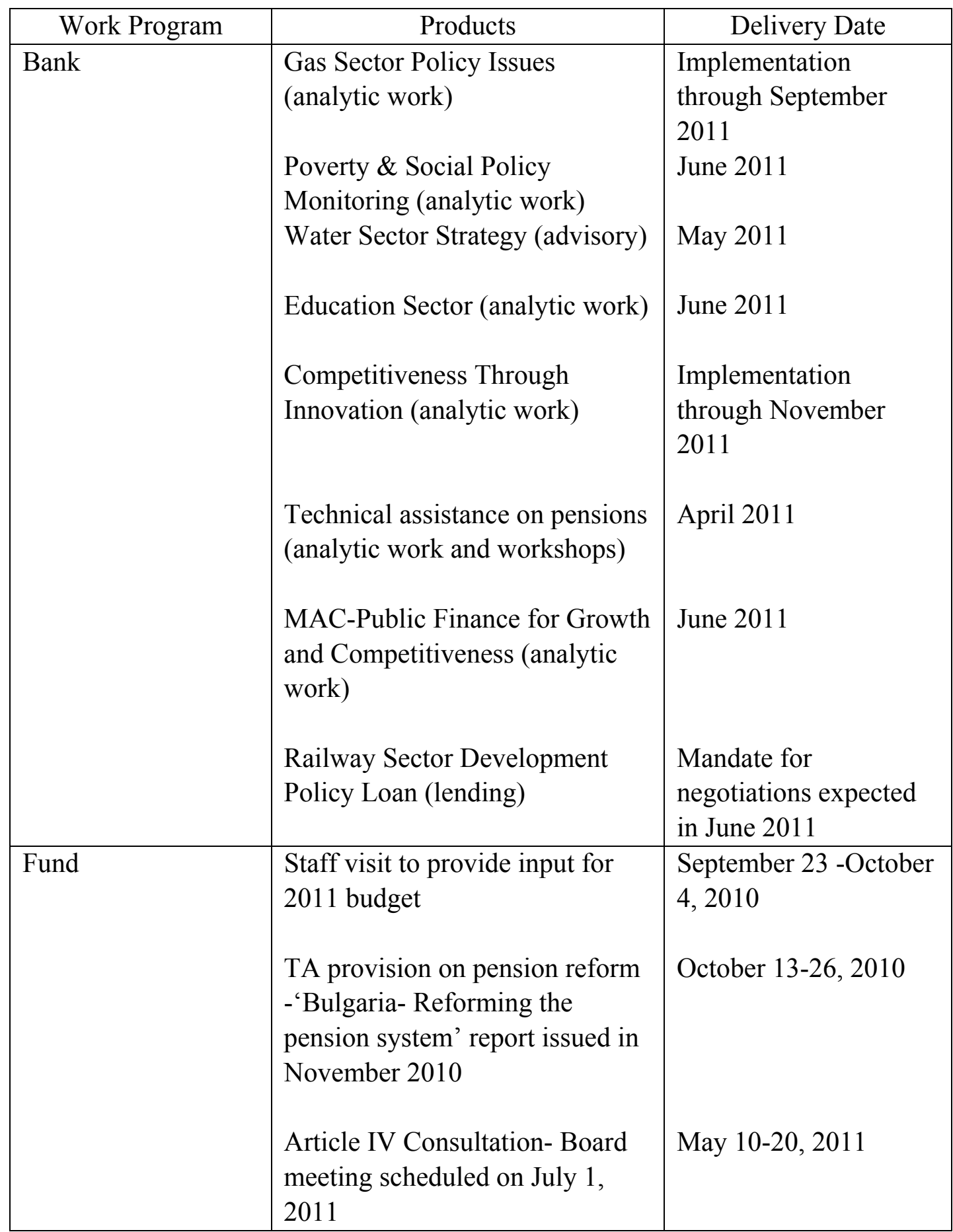




\section{The World Bank Group Strategy and Lending Operations}

6. The Country Partnership Strategy (CPS) for Bulgaria ${ }^{1}$, discussed by the Bank's Board on May 17, 2011, is anchored in Bulgaria's National Reform Program to implement the Europe 2020 Strategy and focused on three main pillars: (i) policy reforms for National Reform Program to implement Europe 2020 Strategy, (ii) strategies and institutions to accelerate EU funds absorption, and (iii) complementing EU financing.

7. The current active Bank portfolio in Bulgaria consists of 4 operations at the total amount of US\$ 353 equivalent. The World Bank's lending program in Bulgaria to date comprises 46 IBRD operations with a total original commitment of US\$3,003 million equivalent, consisting of 15 adjustment loans (US\$1,725.8 million), 24 investment projects (US\$1123 million), one debt reduction loan (US\$125 million), four Bank-managed Global Environmental Fund (GEF) grants, and two Bank-managed Prototype Carbon Fund (PCF) operations. Of these 46 operations, 42 have been completed, of which 13 have been fully or partially cancelled during implementation, and 4 operations are currently under implementation (Table 1).

Table 1. Bulgaria: Active World Bank Operations (Net of Cancellations)

\begin{tabular}{llcc}
\hline & Operation & US\$ million & Board Date \\
\hline 1. & Second Trade and Transport Facilitation in Southeast Europe (TTFSE 2) & 52.8 & 2007 \\
2. & Road Infrastructure Rehabilitation Project & 122.5 & 2007 \\
3. & Social Inclusion Project & 59.0 & 2008 \\
4. & Municipal Infrastructure Development Project & 118.7 & 2009 \\
\hline
\end{tabular}

8. Economic and Sector Work. The country diagnostic work recently completed by the Bank focuses on assessing the quality of education in Bulgaria and review of the Bulgaria's school autonomy reform, long-term care policies for older populations, and better regulation topical studies on: (i) administrative and regulatory barriers to business, (ii) ex-post impact assessment of the Act on Limiting Administrative Regulation and Administrative Control on Economic Activity, and (iii) reforming the regime of state fees.

\section{As of April 30, 2011, IFC has 30 projects (completed and ongoing) in Bulgaria} with total commitments of over US\$ 660 million. The single biggest investment of IFC in the country is in the field of renewable energy in the form of a loan for the construction of the largest wind park in Bulgaria. IFC is also involved in the development of the Galata gas field near the Black sea cost. In line with IFC's strategic goals for Bulgaria, IFC has supported a company investing in agricultural land and promoting land consolidation. In the financial sector, IFC is supporting two specialized SME banks; it established Bulgaria's first

1 International Bank for Reconstruction And Development and International Finance Corporation Country Partnership Strategy for Bulgaria for the period 2011-2013, April 20, 2011. 
micro-lending bank and has invested in a venture fund, which is also targeting the SME sector. In other industries, IFC had contributed to key manufacturing projects in the country - it has supported the modernization and expansion of an electronics producer, a large steel mill, and two glass processing plants. Some IFC projects entail an important environmental component. One of the manufacturing plants, for example, is purchasing equipment which would reduce its GHG emissions and the electronics producing company is making sensors for cars that monitor the emission of polluting gases and improve fuel efficiency.

Questions may be referred to Ms. Stella Ilieva (322-504-0998) and Ms. Sylvia Stoynova (3592-9697-220). 


\section{BUlgaria: Statistical ISSUES}

Data provision is generally adequate for surveillance purposes. Bulgaria participates in the SDDS since 2003.

\section{Real sector}

1. The National Statistical Institute (NSI) is responsible for compiling national accounts, based on a system consistent with the System of National Accounts 1993 (SNA 1993) and the European System of Accounts 1995. GDP data by activity and expenditure categories are compiled and reconciled within an annual supply and use framework. However, government output and final consumption are estimated on a cash basis. In addition, published national accounts include current and capital accounts for the five main domestic sectors (general government and its sub-sectors, financial corporations, nonfinancial corporations, nonprofit institutions serving households, and households). Financial accounts and balance sheets by institutional sectors and sub-sectors are compiled on annual basis since 2006. Quarterly financial accounts and balance sheets are prepared by Bulgarian National Bank.

2. The NSI has compiled estimates of quarterly GDP by the production and expenditure approaches in current and constant prices since 1994. The preliminary flash estimates of GDP and its components by production and expenditure side are produced and disseminated 45 days after the reference period. The quarterly updates are disseminated 70 days after the end of the reference quarter with final figures disseminated after approximately 5 quarters. The annual data are disseminated about 5 quarters after the end of the reference year. The estimates at constant prices, which follow international standards, use chain-linked indices. Problems remain in the coverage of private sector activities as well as regarding constant price estimates of capital formation and external trade, although progress has been made in the development of export and import deflators.

3. On price data, the NSI produces a domestic consumer price index (CPI), a harmonized consumer price index (HICP) according to Eurostat methods, and a producer price index (PPI). All are updated monthly. The CPI series begins in 1995, the PPI in 2000 and the HCPI in 2005 (for earlier years it is set equal to the CPI). The coverage of the CPIs was extended, although they still exclude some important sectors, mainly owner-occupied housing and health and life insurance. Since 2004, financial services are included. Currently, work has started on inclusion of owner-occupied housing in CPI within a Eurostat project. The geographical coverage of the index is restricted to 27 urban areas that account for an estimated 65 percent of sales.

4. The flow of customs data has improved significantly in recent years and a new system for processing customs records is near completion. The development of export and import unit value indices is progressing smoothly and additional support is expected from Eurostat in this area. The current indices are used as deflators for the import and export components of the national accounts. The Import and Export Division of the NSI meets monthly with the 
BNB to review data issues and ensure consistency between the NSI export and import data and the balance of payments data.

5. The national account data on employment and hours worked are compiled by the NSI based on Labor Force Survey and adjusted according to the ESA'95 methodology. The NSI also obtains current monthly estimates from a quarterly survey of establishments using all public enterprises and a sample of private employers that excludes establishments with less than five employees. The sample included 14,500 private employers out of approximately 142,000 qualifying private enterprises. The NSI household labor force survey is an alternative source of data, but improvements are needed to make it more consistent with the establishment survey, especially regarding agricultural employment. The survey is conducted four times a year.

6. The NSI also compiles and publishes wage data for various economic sectors. The main shortcomings include: (i) under-reporting of private sector wages; and (ii) reporting of average gross earnings only, not wages for time worked and wages by occupation. Since 2002, every four years a survey on earnings is conducted which provides information about average monthly and hourly earnings by economic activity, by occupation, by gender and by education. The National Social Security Institute (NSSI) administrative data are currently used to estimate wages by occupation and age (as well as the number of selfemployed and employment in small firms). The household budget survey could provide an alternative source of data for private sector wages.

7. A Population Census was conducted in early 2001 and is a source for redesigning the household surveys conducted by the NSI, particularly the household budget survey and the labor force survey.

\section{Government finance}

8. In recent years, following the recommendations of a combined STA/FAD mission and within the framework of fiscal reporting requirements for EU accession, the authorities have made significant progress on implementing accrual accounting for government, budgetary and statistical systems. Consolidated data on a cash basis, covering general and central government operations, are routinely reported for publication in the GFS

Yearbook/Annual CD-ROM and in IFS. In addition, quarterly accrual GFS data are reported on a quarterly basis for publication in IFS, through Eurostat. Since September 2008, the Ministry of Finance (MOF) prepares and submits the SDDS indicators for the central government finances in the IMF's GFSM 2001 format. The same indicators are published on the MOF's website on a monthly and quarterly basis.

9. The Ministry of Finance prepares data on the execution of the consolidated government budget on a monthly basis, following the national presentation. These data are not according to GFS standards. Aggregate data on revenue, expenditure, balance of the general government and composition of the financing (in national formats) are published in 
the monthly bulletin and posted on the MOF's website, in addition to the GFSM 2001 data. The authorities have made progress in presenting data on a disaggregated basis, including expenditure by functional classification. In addition, a full economic classification of expenditure is now available, and the authorities have provided such data on an annual basis back to 1998 .

\section{Money and banking statistics}

10. BNB reports monetary data for publication in IFS based on the ECB framework for the collection and compilation of monetary data.

\section{Balance of payments}

11. Bulgaria provides quarterly balance of payments (BOP) statistics for dissemination in the IFS on a timely basis. Yearly BOP data are disseminated in the Balance of Payments Statistics Yearbook up to 2009. The BNB derives other sectors investment income data on reinvested earnings, (debit) from the annual direct investment surveys of the NSI, as well as through surveys of the largest foreign-owned enterprises, used for preliminary estimates. Starting from 2002, data series on freight were revised according to a new methodology introduced jointly by the BNB and the NSI. Since joining the EU in January 2007, the trade data with EU countries are being collected following the INTRASTAT system. Data collection for imports and exports with non-EU member states and the movement of goods within the EU are still recorded through customs declaration. 
Table 1. Bulgaria: Common Indicators Required for Surveillance

\begin{tabular}{|c|c|c|c|c|c|c|c|}
\hline \multicolumn{8}{|c|}{ As of May 23, 2011} \\
\hline & \multirow[t]{2}{*}{ Date of latest observation } & \multirow[t]{2}{*}{ Date received } & \multirow{2}{*}{$\begin{array}{c}\text { Frequency } \\
\text { of } \\
\text { data }^{6}\end{array}$} & \multirow{2}{*}{$\begin{array}{c}\text { Frequency } \\
\text { of } \\
\text { reporting }\end{array}$} & \multirow{2}{*}{$\begin{array}{l}\text { Frequency of } \\
\text { publication }\end{array}$} & \multicolumn{2}{|c|}{ Memo Items: } \\
\hline & & & & & & $\begin{array}{c}\text { Data Quality - } \\
\text { Methodological soundness }\end{array}$ & $\begin{array}{l}\text { Data Quality Accuracy } \\
\text { and reliability }\end{array}$ \\
\hline Exchange Rates & May 2011 & 05/19/2011 & $\mathrm{M}$ & $\mathrm{M}$ & M & & \\
\hline $\begin{array}{l}\text { International Reserve Assets and Reserve Liabilities of the } \\
\text { Monetary Authorities } 1\end{array}$ & April 2011 & $05 / 20 / 2011$ & $\mathrm{M}$ & M & M & & \\
\hline Reserve/Base Money & March 2011 & $04 / 27 / 2011$ & $\mathrm{M}$ & $\mathrm{M}$ & $\mathrm{M}$ & $\mathrm{O}, \mathrm{O}, \mathrm{LO}, \mathrm{LO}$ & $\mathrm{O}, \mathrm{O}, \mathrm{O}, \mathrm{O}, \mathrm{O}$ \\
\hline Broad Money & March 2011 & $04 / 27 / 2011$ & $\mathrm{M}$ & $\mathrm{M}$ & $\mathrm{M}$ & & \\
\hline Central Bank Balance Sheet & April 2011 & $04 / 27 / 2011$ & $\mathrm{M}$ & $\mathrm{M}$ & $\mathrm{M}$ & & \\
\hline Consolidated Balance Sheet of the Banking System & March 2011 & 04/27/2011 & $\mathrm{M}$ & M & M & & \\
\hline Interest Rates $^{2}$ & March 2011 & $04 / 29 / 2011$ & $\mathrm{M}$ & M & M & & \\
\hline Consumer Price Index & April 2011 & $05 / 12 / 2011$ & $\mathrm{M}$ & M & M & $\mathrm{O}, \mathrm{LO}, \mathrm{O}, \mathrm{O}$ & LO, LO, O, O, O \\
\hline $\begin{array}{l}\text { Revenue, Expenditure, Balance and Composition of } \\
\text { Financing }{ }^{3} \text { - General Government }\end{array}$ & Dec 2010 & $04 / 26 / 2011$ & A & A & A & $\mathrm{O}, \mathrm{LO}, \mathrm{O}, \mathrm{LO}$ & $\mathrm{LO}, \mathrm{O}, \mathrm{O}, \mathrm{O}, \mathrm{NO}$ \\
\hline $\begin{array}{l}\text { Revenue, Expenditure, Balance and Composition of } \\
\text { Financing }{ }^{3} \text {-General Government }{ }^{4}\end{array}$ & Dec 2010 & $04 / 26 / 2011$ & $\mathrm{M}$ & M & M & & \\
\hline $\begin{array}{l}\text { Stocks of General Government and General Government- } \\
\text { Guaranteed Debt }\end{array}$ & Dec 2010 & $04 / 26 / 2011$ & $\mathrm{M}$ & M & M & & \\
\hline External Current Account Balance & $2010 \mathrm{Q} 4$ & $04 / 12 / 2011$ & Q & Q & Q & LNO, LO, O, LO & LNO, LNO, LNO, LO, LO \\
\hline Exports and Imports of Goods and Services & 2010 Q4 & $04 / 12 / 2011$ & Q & Q & Q & & \\
\hline GDP & 2011 Q1 (flash estimate) & $05 / 13 / 2011$ & Q & Q & Q & $\mathrm{O}, \mathrm{LO}, \mathrm{O}, \mathrm{LO}$ & $\mathrm{O}, \mathrm{O}, \mathrm{O}, \mathrm{O}, \mathrm{O}$ \\
\hline Gross External Debt & 2010 Q4 & $04 / 12 / 2011$ & Q & Q & Q & & \\
\hline
\end{tabular}

${ }^{1}$ Includes reserve assets pledged or otherwise encumbered as well as net derivative positions. ${ }^{2}$ Both market-based and officially-determined, including discount rates, money market rates, rates on treasury bills, notes and bonds. ${ }^{3}$ Foreign, domestic bank, and domestic nonbank financing. ${ }^{4}$ On a gross cash basis. The general government consists of the central government (budgetary funds, extra budgetary funds, and social security funds) and local governments. ${ }^{5}$ Including currency and maturity composition. ${ }^{6}$ Daily (D); Weekly (W); Monthly (M); Quarterly (Q); Annually (A); Irregular (I); Not Available (NA). ${ }^{7}$ Reflects the assessment provided in the data ROSC published in December 2003, which is based on the findings of the mission that took place during January $15-30$, 2003 for the dataset corresponding to the variable in each row. The assessment indicates whether international standards concerning (respectively) concepts and definitions, scope, classification/sectorization, and basis for recording are fully observed (O), largely observed (LO), largely not observed (LNO), or not observed (NO). ${ }^{8}$ Same as footnote 7, except referring to international standards concerning (respectively) source data, statistical techniques, assessment and validation of source data, assessment and validation of intermediate data and statistical outputs, and revision studies. 


\section{INTERNATIONAL MONETARY FUND}

Public Information Notice

\section{IMF Executive Board Concludes 2011 Article IV Consultation with Bulgaria}

Public Information Notice (PIN) No. 11/85

FOR IMMEDIATE RELEASE

July 8,2011
International Monetary Fund

$70019^{\text {th }}$ Street, NW

Washington, D. C. 20431 USA

On June 29, 2011, the Executive Board of the International Monetary Fund (IMF) concluded the Article IV consultation with Bulgaria. ${ }^{1}$

\section{Background}

Bulgaria's recovery from crisis has been marked by remarkable adjustment. After contracting 5.5 percent in 2009, the economy stabilized in 2010 growing 0.2 percent on the back of strong export growth. Bulgaria's exports, which benefited from revived global demand and high international commodities prices, recovered to pre-crisis levels. Imports, however, remained subdued in line with depressed domestic demand stemming from high unemployment and economic uncertainty. The accompanying adjustment in external imbalances reduced the current account deficit from 23 to 1 percent of GDP between 2008 and 2010. With considerable slack in the economy, core inflation averaged one percent in 2010, but rising energy and food prices drove average headline inflation to 3 percent.

Strong policy action and large fiscal and financial sector buffers helped Bulgaria weather the crisis well. Past fiscal surpluses saved in the fiscal reserve account boosted international reserves, underpinned confidence in the currency board arrangement, and financed recent deficits (3.9 percent in 2010, cash-basis). This combined with the prompt action to adjust government spending to the decline in revenues contained the

\footnotetext{
${ }^{1}$ Under Article IV of the IMF's Articles of Agreement, the IMF holds bilateral discussions with members, usually every year. A staff team visits the country, collects economic and financial information, and discusses with officials the country's economic developments and policies. On return to headquarters, the staff prepares a report, which forms the basis for discussion by the Executive Board. At the conclusion of the discussion, the Managing Director, as Chairman of the Board, summarizes the views of Executive Directors, and this summary is transmitted to the country's authorities. An explanation of any qualifiers used in summings up can be found here: http://www.imf.org/external/np/sec/misc/qualifiers.htm.
} 
fiscal deficit and debt, and created the conditions for a quick exit from EU excessive deficit procedure. In the financial sector, non-performing loans had risen to 12.9 percent by end-March 2011. However, the capital adequacy ratio remained high at 17.7 percent and the banking system was profitable. Bulgaria's high level of capital and conservative regulatory regime going into the crisis enabled the BNB to ease its regulatory requirements allowing banks to utilize some of their capital and provisioning buffers to absorb losses.

The recovery is expected to broaden to domestic demand. In 2011, real GDP is projected to rise to 3 percent as continued strong export growth stimulates investment. As unemployment gradually declines, consumption will also gain momentum allowing real GDP to recover its pre-crisis levels in 2012. Pressures from food and energy price increases are expected to ease in the latter half of the year helping contain average HICP inflation to $4 \frac{1}{4}$ percent in 2011. Over the medium term, growth is expected to recover to about 4 percent reflecting the rebalancing between domestic and external demand. Against this backdrop, the current account deficit is expected to be contained to moderate levels.

\section{Executive Board Assessment}

Executive Directors commended the authorities for sound policies that helped Bulgaria weather the global crisis and paved the way for the export-led recovery underway. The challenge going forward will be to rebuild policy buffers to address external risks, and to speed up the pace of reforms to boost economic resilience and medium-term growth prospects.

Directors welcomed the authorities' 2011 deficit target, which implies a timely exit from the EU's excessive deficit procedure. They noted that strengthening tax compliance and resisting spending pressures in the run up to elections are essential to achieve this target, and were reassured by the authorities' intention to take additional measures, if necessary.

Directors emphasized that, over the medium term, it will be important to improve the quality and durability of the fiscal consolidation effort. Deeper reforms in health, public administration, and pensions would free policy space, improve service delivery, and address aging-related pressures. Directors supported the proposed Financial Stability Pact, and encouraged the adoption of a complementary fiscal rule that could help avoid policy pro-cyclicality. A few Directors encouraged the authorities to pursue more ambitious medium-term fiscal goals, given the need to reconstitute fiscal buffers.

Directors noted that the banking system remains well-capitalized, liquid, and stable, but recommended continued vigilance to head off potential risks. Directors welcomed the improvement in liquidity indicators at banks, but noted the relatively high level of non-performing loans and, in some cases, the continued reliance on support from parent 
institutions abroad. In light of the linkages with fiscally distressed euro-area economies, Directors saw merit in further developing contingency plans and back-stop arrangements, and, more broadly, encouraged the authorities to continue to monitor closely the banking system in coordination with home supervisors. In addition, the easing of prudential regulations implemented during the crisis should be reversed and the corporate debt resolution framework should be strengthened.

Directors considered that stepped up structural reforms hold the key to improved growth prospects. Taking note of the staff's assessment that the exchange rate is broadly in line with medium-term fundamentals, they stressed that wage growth should be better aligned with productivity developments to safeguard competitiveness. Initiatives underway to reduce skills mismatch, decrease administrative burdens, strengthen the legal system, and improve the absorption of EU funds will also be essential to the achievement of a higher growth path.

Public Information Notices (PINs) form part of the IMF's efforts to promote transparency of the IMF's views and analysis of economic developments and policies. With the consent of the country (or countries) concerned, PINs are issued after Executive Board discussions of Article IV consultations with member countries, of its surveillance of developments at the regional level, of post-program monitoring, and of ex post assessments of member countries with longer-term program engagements. PINs are also issued after Executive Board discussions of general policy matters, unless otherwise decided by the Executive Board in a particular case. 
Table 1. Bulgaria: Selected Economic and Social Indicators, 2008-12

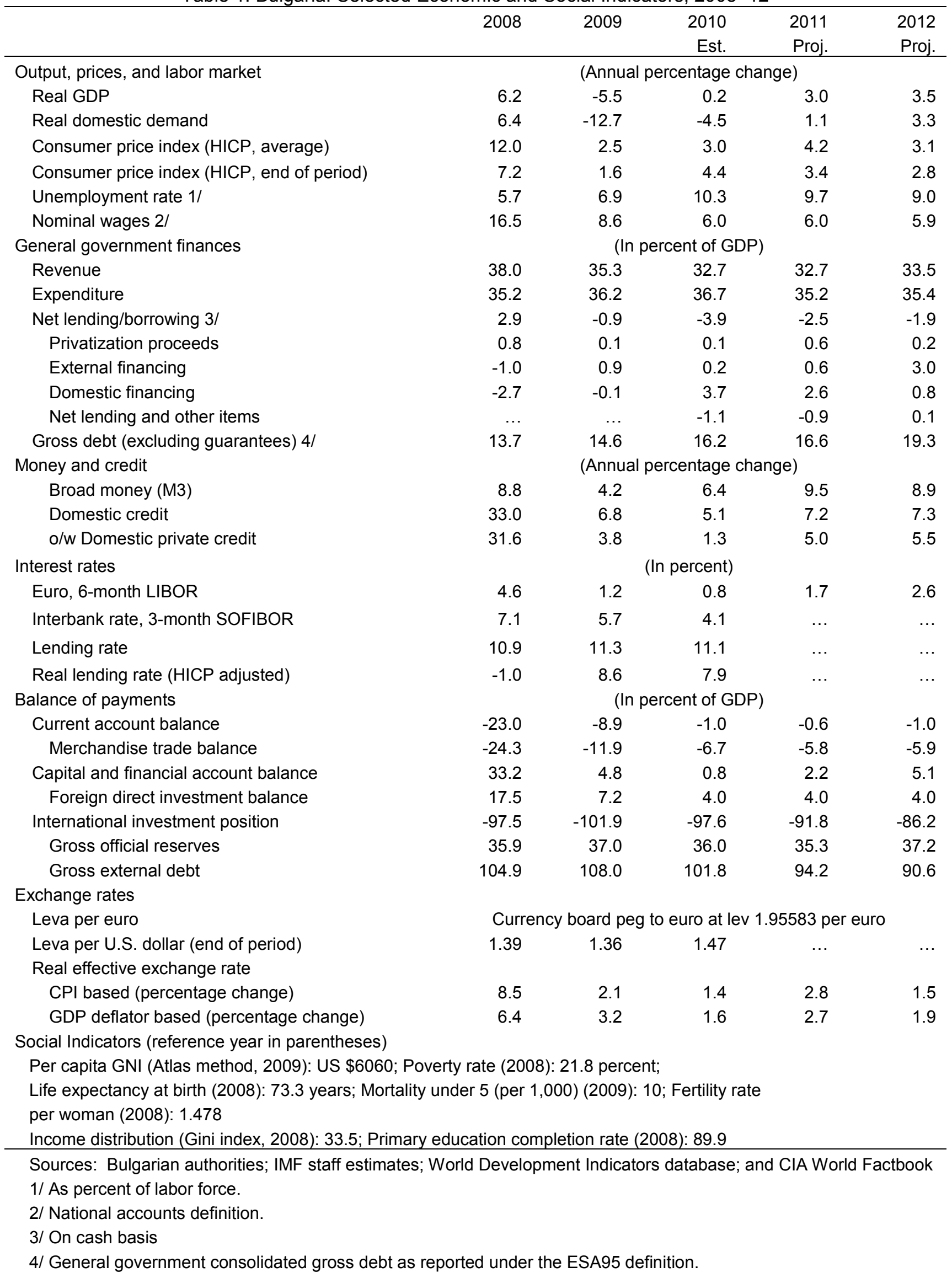




\section{Statement by Mr. Age Bakker, Executive Director for Bulgaria And Tsvetan Manchev, Adivsor to the Executive Director June 29, 2011}

The Bulgarian authorities remain committed to prudent macroeconomic policies which promote sustainable growth. They appreciate the constructive dialogue with the Fund and broadly share the staff's policy advice as presented in the Article IV report.

\section{Recent Macroeconomic Developments}

Since the last Article IV consultation, the authorities have made substantial policy efforts. The economy has demonstrated considerable agility, resulting in the closing of external imbalances and recovery from the crisis. Q1 GDP growth, led by high net export growth, reached 3.4 percent year-on-year ( 0.6 percent quarter-on-quarter). Domestic demand remains suppressed.

Labor productivity has increased from the beginning of the year, following the rise in unemployment and subsequent moderation in wage growth. This has boosted further the competitiveness of the Bulgarian economy. Since February 2011 the current account, on a 12-month moving basis, turned positive, for the first time in many years. The current account showed a surplus of 0.6 percent of GDP for January-April 2011 against a deficit of 2 percent of GDP for January-April 2010. At the same time foreign direct investment, which had fueled pre-crisis growth, decreased, mainly due to net payments on intercompany credits in accordance with loan repayment schedules.

After a period of acceleration in the latter part of 2010 and the beginning of 2011 due to the base effect from an excise hike on tobacco and alcohol, HICP inflation decelerated to 3.4 percent in May. The pressures from the recent surge in world energy prices are easing, following the gentlemen's agreement between the government and "Lukoil Bulgaria" which led to a 2.6 percent monthly decline in retail fuel prices in May. Although still contributing significantly to HICP inflation, the growth of food prices also decelerated last month. After two years of decline real estate prices are showing signs of stabilization.

The authorities are cognizant that the sustainability of the recovery faces challenges, many of which are of an external nature, but they remain optimistic. They monitor the EU-IMF comprehensive response and financial assistance to the Euro Area periphery and believe that it will help in containing these risks. The authorities are committed to further accelerate structural reforms and boost competitiveness as designed in the recent update of the National Reform Program (NRP). The strong commitment of all political players to the Currency Board Arrangement (CBA) - supported by a more than adequate reserve level (coverage of imports of above 6.5 months) - is an additional buffer against shocks. 


\section{Fiscal Policy}

The authorities are well aware that fiscal policy remains a crucial shock absorber. They used the 2011 rebound of the economy for implementing another round of fiscal consolidation to bring the deficit further down. On the revenue side, tax policies remain broadly unchanged as part of the strategy to provide businesses a stable and predictable environment. The restructuring of tax and customs administration will lead to greater efficiency of tax collection and eradication of financial fraud and tax evasion. On the expenditure side, the authorities' strategy envisages a continued real contraction of spending to the lower levels of post-boom revenues. The contraction is pursued by the imposition of tight ceilings, including wage and pension bill freezes.

Performance up till now suggests that the 2011 deficit target of 2.5 percent of GDP (ESA 95 methodology) will be met, which would secure a pronounced exit from the EU excessive deficit procedure. In case of deterioration of the external environment or of revenue performance in the second half of the year, the authorities are committed to consider additional measures. The fiscal reserve has served the authorities well as a liquidity buffer during the crisis and in their view remains sufficient to meet their needs. They plan to rebuild the reserve over time, but do not consider substantial debt issuance in 2011.

As part of the long-term strategy toward fiscal sustainability the authorities have initiated the introduction of the Financial Stability Pact. The government submitted a draft for constitutional and legislative amendments to Parliament. Although not included in the current version of the Pact, the alternative fiscal rules proposed by the Fund are being carefully analyzed in the Ministry of Finance and may be incorporated during the next round of discussions in September 2011. The current version of the Pact envisages a deficit ceiling, which is set tighter than that of the EU Stability and Growth Pact, together with an upper limit of expenditures to 40 percent of GDP and subjects changes in direct taxes to a constitutional majority vote.

\section{Monetary and Macro-prudential Policies and Financial Sector Development}

The CBA has proved its flexibility and sustainability both during the boom prior to the crisis and in the cyclical downturn. It has continuous support from macro-prudential policies. The BNB recently increased from 6 to 12 months the term for realization of collateral provided in the form of buildings or land. This will have an anti-cyclical effect, taking into consideration the current liquidity conditions in the real estate market and the need to preserve flexible relations with bank customers facing temporary liquidity problems. In thus balancing the need to alleviate banks' capital position and preserve capital buffers so far accumulated, the BNB preserves the consistent conservative nature of its supervisory policy. 
The financial system, dominated by the banking sector, remains stable, well capitalized and highly liquid, and so are individual banks. By the end of Q1 2011, the banking system's capital adequacy ratio was 17.7 percent, with Tier 1 at 15.4 percent. As of 30 April 2011, the liquid asset ratio preserved its high level at 23.7 percent. Of course, in the highly uncertain international environment, the authorities monitor the situation very closely on a day-to-day basis. They have intensified contacts with bank management and home country supervisors and have increased the frequency of reporting.

The strong and persistent risk-aversion of the supervisory authorities has led to a more diversified funding structure with less reliance on foreign funding in the post-crisis period. Deposits of households have continued to increase and most recent developments suggest stabilization of asset quality. The rates of increase in impairment costs and specific provisions for credit risk were similar in April to those registered in January. The banks have weathered the crisis relatively well because of the years of conservative provisioning and stringent evaluation of collateral. Operating revenue has exceeded operating expenses and impairment costs during the downturn, and the majority of the banks remain profitable.

The restructuring among small banks has progressed well and they have resumed credit growth. The 0.8 percent monthly increase in corporate lending in April was the biggest monthly increase since the beginning of the year. Lending to households remained largely flat. The market share of small and medium-sized banks has continued to increase steadily. The domestic wholesale banking market remains stable with the overnight money market interest rate currently below 0.20 percent.

\section{Structural Reforms}

The authorities are fully aware that sustainable economic growth requires further structural reforms to provide strong financial footing to the pension, healthcare, education and railroad transportation systems. Based on the recommendations provided by the Fund's TA mission in late 2010, the authorities implemented a package of measures ensuring the long-term financial stability of the Bulgarian pension system and better adequacy of pensions. As an immediate step, following a decade of decreasing rates, the social contribution rate was raised by $1.8 \mathrm{pp}$. The length of service is increased as of 2012, followed by a gradual increase in the statutory retirement age. These measures, together with structural reforms in the labor market, aim at a steady increase in economic activity and will neutralize the burden of an ageing population in the future without jeopardizing the stability of public finances.

The health care reform targets higher efficiency of health care expenditures combined with measures for improving public health, higher national health security and stabilizing healthcare system infrastructure. Starting from 2011, an integrated information system is developed to link in real time the information systems of healthcare institutions and their contractors. The system will connect existing systems of several institutions with the 
healthcare service providers and will guarantee timely and accurate exchange of information among all participants as a basis for regular assessment of the health insurance system, monitoring and optimal decision making in the sector. Work on developing electronic registers, electronic prescriptions, and electronic referrals will continue, and already existing registers will be integrated into a unified information system with some of them publicly accessible through web-portals. At the next stage, an electronic patients dossier will be developed and maintained.

The need for fiscal consolidation necessitates additional measures to increase the financial independence of the education sector, including through attracting private capital, which in turn will improve the links between the educational system and the labor market. These new practices in financing the Bulgarian education and pre-school education are defined in detail in the new Law on Pre-School and School Education, which is to be adopted in 2012. The implementation of these measures will also enhance the transparency of public expenditures and its effectiveness through financing the educational system output, will accelerate school network optimization, and will contribute to broader pupil coverage through linking financing and the number of students.

The World Bank will provide assistance for institutional reforms in education. The assistance will be targeted both at improving the quality of the primary and secondary education through strengthening the schools' reporting system and improving the system of external evaluation of the quality of education, and at improving the quality and significance of higher education through better management in higher schools, stricter control over their accreditation and linking the government financing to output.

The restructuring of the railroad companies has already started as a prior action for financing from the World Bank. The plans aim at better cost recovery, competitive tendering for public services and infrastructure maintenance and abolishment of losses and liquidation of arrears.

The authorities have given high political priority to addressing various problems with the low rate of EU funds utilization. In 2011 the ambitious goal is to increase annual absorption of EU funds to the level equal to the total absorption for the period 2007-10. It is expected that the goal will be comfortably met. 